Fordham Law School

FLASH: The Fordham Law Archive of Scholarship and History

Faculty Scholarship

2021

\title{
COVID-19 and Comparative Corporate Governance
}

\author{
Martin Gelter \\ Fordham University School of Law, mgelter@law.fordham.edu \\ Julia M. Puaschunder \\ Columbia University, julia.puaschunder@columbia.edu
}

Follow this and additional works at: https://ir.lawnet.fordham.edu/faculty_scholarship

Part of the Law Commons

\section{Recommended Citation}

Martin Gelter and Julia M. Puaschunder, COVID-19 and Comparative Corporate Governance, 46 J. Corp. L. 557 (2021)

Available at: https://ir.lawnet.fordham.edu/faculty_scholarship/1145

This Article is brought to you for free and open access by FLASH: The Fordham Law Archive of Scholarship and History. It has been accepted for inclusion in Faculty Scholarship by an authorized administrator of FLASH: The Fordham Law Archive of Scholarship and History. For more information, please contact tmelnick@law.fordham.edu. 


\section{COVID-19 and Comparative Corporate Governance}

\section{Martin Gelter $^{*} \&$ Julia M. Puaschunder ${ }^{* *}$}

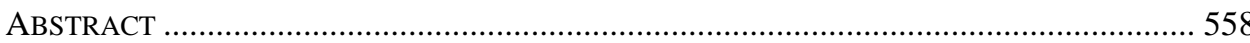

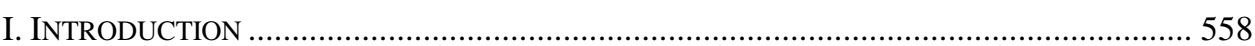

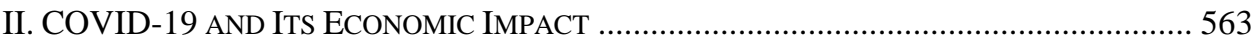

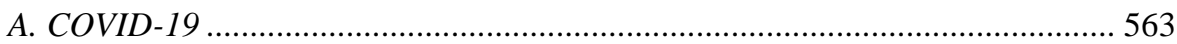

B. Economic Losses Resulting from COVID-19 ……………............................. 563

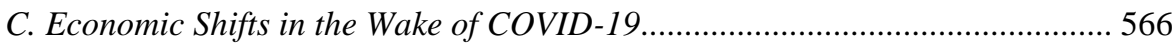

III. COMPARATIVE CORPORATE GOVERNANCE: CRISIS AS A DETERMINANT AND

ACCELERATOR OF LONG-TERM TRENDS ......................................................... 569

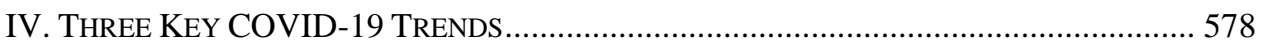

A. The Turn from "Efficient" to Resilient Structures ............................................ 578

1. Corporate Fat and the Agency Cost of Free Cash Flow ............................ 578

2. Relational Equity and Debt, and Corporate Embeddedness ........................ 586

3. Human Capital and the Value of a Healthy Labor Force ........................... 590

i. Building a Resilient Workforce ............................................................. 590

ii. Consequences for the Relationship Between Capital and Labor ........... 594

B. The Return of Nationalism in Corporate Governance .................................... 596

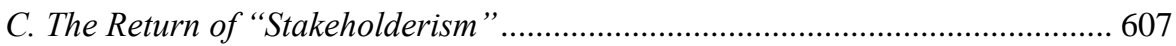

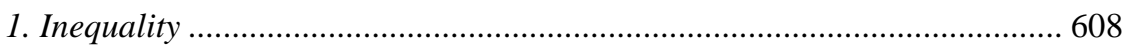

2. Climate Change, Institutional Shareholder Stewardship, and Other

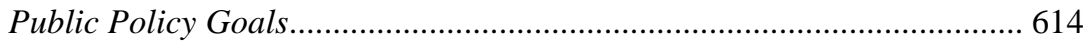

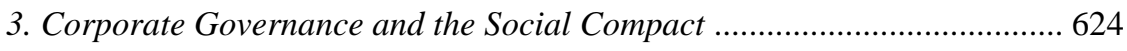

V. COVID-19 AND THE EVOLUTION OF COMPARATIVE CORPORATE GOVERNANCE ...... 624

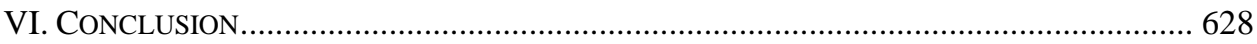

\footnotetext{
* Fordham University School of Law; Research Member, European Corporate Governance Institute.

** Columbia University; The New School, Department of Economics and The New School for Public Engagement. For helpful comments, we thank participants of a roundtable event of the alumni association of the Vienna University of Technology, the 5th Annual Meeting of the French Association for Law and Economics (AFED), the Fordham Law School Faculty Workshop, the 16th Annual Conference of the Italian Society for Law and Economics (SIDE-ISLE), the Association of American Law Schools (AALS) 2021 Annual Meeting, as well as Mariana Pargendler, Elizabeth Pollman, Siegfried Sharma, Mathias Siems, Richard Squire, and Massimiliano Vatiero. We also thank Grace Lee and Steven Cotto for excellent research assistance.
} 


\section{ABSTRACT}

With the pandemic caused by the novel coronavirus SARS-CoV-2 raging around the world, many countries' economies are at a crucial juncture. The COVID-19 external shock to the economy has the potential to affect corporate governance profoundly. This Article explores its possible impact on comparative corporate governance. For an economy to operate successfully, a society must first find a politically sustainable social equilibrium. In many countries, historical crises-such as the Great Depression and World War IIhave resulted in a reconfiguration of corporate governance institutions that set the course for generations. While it is not yet clear whether COVID-19 will have a similar effect, it is possible that it will change patterns of what kind of firms are-from an evolutionary perspective-likely to survive, and which ones are not. We argue that to some extent, it will accelerate ongoing trends, whereas in other areas it put corporations on an entirely new course. We observe three trends, namely the need for resilience, a growth of nationalist policies in corporate law, and an increasing orientation toward "stakeholder" interests. First, firms will have to become resilient to the crisis and consequently long-term oriented. Corporations that are not operating merely on an arm's length capital market basis but are integrated into a network, generated by core shareholders, state ownership, or bank lending may be more likely to survive. In addition, firms are beginning to interact with their workforce differently in their attempts to maintain what could be called "healthy human capital." Second, we are likely to see a resurgence of nationalism in corporate governance to ensure that foreign ownership and interconnected supply chains do not put national security at risk. Third, the existing critiques of inequality but also climate change awareness will accelerate the trend toward a broadening of corporate purpose toward "stakeholderism" and public policy issues. As in the past years, institutional investors acting as "universal owners" will play a role in shaping this trend.

\section{INTRODUCTION}

When the novel coronavirus SARS-CoV-2 emerged in Wuhan, China, in December 2019, some epidemiology experts were alarmed, but the general public in much of the world, let alone business leadership, did not take notice or was not particularly concerned. A year into the outbreak of the pandemic, almost two million individuals have died, the disease has affected close to a hundred million people, ${ }^{1}$ and it has touched the lives of all of us. Around the world, countries have taken harsh measures to combat the disease, including lockdowns that have caused huge disruptions to work, life, and the economy.

Not surprisingly, corporate governance is at a critical juncture as well. As the COVID19 pandemic rages around the globe, firms have struggled to survive lockdowns with severe effects on the economy. Restrictions have caused GDP drops and increased unemployment to levels worse than that of the Great Depression. ${ }^{2}$ While an end to COVID-19

1. For recent data, see Coronavirus Cases, WORLDOMETER, https://www.worldometers.info/coronavirus/ [https://perma.cc/LG5J-ATYL].

2. See, e.g., Jeffrey D. Sachs et al., The Lancet COVID-19 Commission, 396 LANCET 454, 455 (2020) 
is in sight with vaccinations and medical innovations, it remains unclear how long the pandemic will last and how severe its economic effects will ultimately be. This Article argues that COVID-19 will have a lasting effect on corporate governance around the world. We suggest that large corporations will be run and controlled differently, and the interaction between firms and their shareholders and other stakeholders will change as a result of the pandemic. The balance between the interest groups dominating corporate governance internationally may change.

The pandemic will not necessarily entail a clean break-i.e., there will not be a postCOVID corporate governance that is sharply distinct from its antecedent. The financial crisis of 2008-09 has already set some trends in motion that will accelerate because of the shock brought about by the novel coronavirus. ${ }^{3}$ On this point, the pandemic is not unprecedented. While corporate governance tends to evolve gradually during times of peace, prosperity, and growth, historical examples show that it takes leaps during periods of severe social and economic disruptions. Specifically, the structures that characterized corporate governance in the second half of the 20th century emerged as a result of the disruptions during its first half, most of all the Great Depression and World War II, in some of the major wealthy jurisdictions. ${ }^{4}$ Consequently, the United States and the United Kingdom developed dispersed ownership structures and deep capital markets, while other developed economies, in particular Continental European jurisdictions such as Germany, had concentrated ownership and lacked similarly developed stock markets. ${ }^{5}$ Japan, another country deeply involved in and affected by World War II, emerged from this period with a unique cross-ownership structure. ${ }^{6}$

While the second half of the 20th century certainly did not eschew economic disruptions, overall the economy resembled a ship sailing through comparatively calm waters. Especially during the later decades, corporate governance in many countries seemed on the way toward what traditional corporate governance scholars would consider efficient structures. Starting in the United States and the United Kingdom, the law and markets began to be increasingly oriented toward the interests of outside investors. During the 1990s and 2000s, many countries in Europe and Asia began to move increasingly toward this "shareholder model," resulting in a debate about convergence in corporate governance. ${ }^{7}$ With the 2008-09 financial crisis, fissures in this model began to emerge.

We argue that the COVID-19 pandemic, as an exogenous shock with the potential to change many aspects of the economy, will push corporate governance further away from shareholder orientation by turning around a number of trends and accelerating other shifts that have already begun during the past ten years. We suggest that change will occur

(providing information on the economic impact of the COVID-19 pandemic).

3. Infra notes $131-135$ and accompanying text.

4. E.g., Alan J. Dignam \& Michael Galanis, The Globalization of Corporate Governance xv, xviii, 15, 96, 208, 254, 395 (2009) (arguing that amending corporate governance systems does not create the certainty that people often desire).

5. E.g., Mark J. Roe, German Codetermination and German Securities Markets, 1998 CoLUM. Bus. L. REV. 167, 167 (1998) (explaining Germany's lack of good securities markets).

6. E.g., Julian Franks et al., The Ownership of Japanese Corporations in the 20th Century, 27 REV. FIN. STUD. 2580, 2581 (2014) (describing the transformation of Japanese corporate governance after World War II).

7. Infra notes 120-130 and accompanying text. 
broadly in three areas - a turn from "efficient" to "resilient" corporate governance structures, the return to nationalism in corporate law and governance, and a strengthening of an existing tendency toward what can be called "stakeholderism."

First, we argue that firms will abandon certain practices that are usually considered efficient in favor of resiliency. Over the past decades, companies have developed crossborder supply chain networks and just-in-time logistics, ${ }^{9}$ which are difficult to maintain as countries re-erect economic barriers. Similarly, on the financial side, companies have slimmed down and reduced corporate "fat" by taking on debt and returning excess cash to shareholders in the form of dividends and share repurchases. ${ }^{10}$ All of these practices tend to be beneficial in an economically stable environment characterized by growth, but they are detrimental when firms need to weather a storm.

In addition, during the debate about convergence in corporate governance analysts have extolled companies with dispersed ownership that are consequently most attentive to the interests of outside investors. ${ }^{11}$ At least, this is the general picture we have of firms in the "Anglo-Saxon" systems of the United States and the United Kingdom. ${ }^{12}$ Supported by tentative early evidence, we suggest that firms that are part of a larger network are more likely to survive hard times. Such a network could be integrated into a corporate group, concentrated ownership, or close links to the government.

Finally, we argue that resiliency will increasingly require firms to ensure they work toward developing a healthy workforce. Thus, traditional human capital theories of the capital-labor interaction will have to be supplemented by "healthy human capital." In part, this means that firms will have incentives to hire staff that does not fall into a risk group, which raises the specter of discrimination. ${ }^{13}$ However, it also means that firms will need to develop practices that avoid contagion with their long-term workforce to the extent that it still needs to interact physically. The degree of physical interaction depends on the nature of the job. The increasing digitalization of the workforce, which has been accelerated by the pandemic, may influence the relative bargaining power of capital and labor. The specific new balance will depend largely on the degree of digitalization of the employee's job, and on the specificity of their human capital. Digitalization may also make human capital less firm-specific because employers may be able to draw on a larger recruiting pool.

8. The term refers to the idea that large companies should not only serve the interests of shareholders, but their other "stakeholders" as well. E.g., Lucian Bebchuk \& Roberto Tallarita, 'Stakeholder' Capitalism Seems Mostly for Show, WALL ST. J. (Aug. 6, 2020, 7:07 PM), https://www.wsj.com/articles/stakeholder-capitalismseems-mostly-for-show-11596755220 [https://perma.cc/ZQB8-MRAK].

9. Hing Kai Chan et al., Implementing Just-in-Time Philosophy to Reverse Logistics Systems: A Review, 48 INT'L J. PROD. RsCH. 6293, 6295-96 (2010); Richard Baldwin \& Javier Lopez-Gonzalez, Supply-Chain Trade: A Portrait of Global Patterns and Several Testable Hypotheses, 38 WORLD ECON. 1682, 1682 (2015).

10. Infra notes 148-167 and accompanying text. (2001).

11. Henry Hansmann \& Reinier Kraakman, The End of History for Corporate Law, 89 GEO. L.J. 439, 443

12. Rafael La Porta et al., Corporate Ownership Around the World, 54 J. Fin. 471, 491-98 (1999).

13. Reinhardt Stefan Tomek et al., Salzburg Declaration, Outcome of the Conference on "System Change?! The Chance of Transformation of the Healthcare Sector: Analysis and Chance Within the Coronavirus Crisis", (Sept. 2020), https://europepmc.org/article/ppr/ppr242581 [https://perma.cc/2RPH-LZMN] [hereinafter Salzburg Declaration]. 
Second, we propose that we will see a greater significance of nationalism and/or protectionism in corporate law. During the past decades, government ownership of parts of the economy has generally had a bad name because of its perceived inefficiencies. ${ }^{14}$ And yet, we are already seeing its limited resurgence in key companies that are being bailed out. A major element of this is an increasing concern that countries want to avoid becoming dependent on international investors with political motives, such as firms affiliated with the People's Republic of China. ${ }^{15}$ Western countries are increasingly concerned about the distribution of valuable goods and resources, such as medication, being put at risk by politically tainted supply chains. The United States and the EU have therefore already strengthened their foreign direct investment (FDI) rules. ${ }^{16}$ However, government ownership is only the strongest version of corporate nationalism. More limited aspects include "Golden Shares," where public actors reserve the right to veto certain decisions, ${ }^{17}$ and the ability for firms to defend against (foreign) takeovers. ${ }^{18}$ We are likely to see a movement away from limitations of these two. Finally, particularly in Europe, we will likely see pressure on certain elements of EU law intended to create a level playing field in the internal market, such as state aid law — which restricts subsidies - and public procurement law. ${ }^{19}$

Third, we are likely to experience a return of "stakeholderism" in corporate governance. Stakeholders are "constituencies" of the firm besides shareholders to whose interests a corporation is expected to give regard. ${ }^{20}$ In addition to concerns of labor, we identify an increasing concern for two public policy issues. First, the pandemic and the economic fallout of the lockdowns have exacerbated economic inequality in many jurisdictions. An increasing number of industries are being disrupted by digitalization, rendering some past human capital investment useless. Furloughed and laid-off workers are losing their livelihood and will have to dip into their savings. A number of proposals to address this issue have been brought forward in corporate governance, including employee participation on the board, which - after decades of criticism - seems to be gaining ground in Europe again. ${ }^{21}$ In addition, the Business Roundtable's 2019 statement on corporate purpose has abandoned shareholder wealth maximization for a stakeholder conception of the corporation. $^{22}$ This is not a movement unique to the United States, but we are seeing parallels in other jurisdictions. Second, climate change has not entirely disappeared from the public eye and is likely to come back as a more intense discussion during the coming years. Interestingly, on both issues we are seeing an increased pressure from the financial industry for

14. Mariana Pargendler, State Ownership and Corporate Governance, 80 FORDHAM L. REV. 2917, 2958 (2012).

15. Jeffrey N. Gordon \& Curtis J. Milhaupt, China as a "National Strategic Buyer": Toward a Multilateral Regime for Cross-Border M\&A, 2019 Colum. Bus. L. REV. 192, 212-13 (2019).

16. Infra notes $268-274$ and accompanying text.

17. Infra notes 290-292 and accompanying text.

18. Infra notes 296-309 and accompanying text.

19. Infra notes $318-325$ and accompanying text.

20. Bebchuk \& Tallarita, supra note 8

21. Infra notes 132-36, 345-49 and accompanying text.

22. Statement on the Purpose of a Corporation, Bus. RoundTABLE (Aug. 19, 2019), https://s3.amazonaws.com/brt.org/BRT-StatementonthePurposeofaCorporationOctober2020.pdf [https://perma.cc/3KXWJE7K]. 
corporations to adjust and address them on the company level. Moreover, since governments in many countries have become more involved in the economy with COVID-19, it is possible that it will use these "war powers" ${ }^{23}$ to address other pressing concerns.

Overall, these consequences allow us to draw larger lessons for (comparative) corporate governance. We may see a reconfiguring of institutions in many jurisdictions. Corporate governance has often been analogized to biological evolution. While the shock of the pandemic had an immediate effect on many firms, it is likely to change the larger economic environment for years to come as lockdowns and smaller shocks come and go. Thus, we are likely to see persistent effects.

In biology, evolutionary processes do not always happen gradually, but we sometimes see (apparent) leaps in the fossil record, which has inspired the evolutionary theory of punctuated equilibrium. ${ }^{24}$ The law, which evolves memetically rather than genetically, ${ }^{25}$ is even more amenable to leaps. Suddenly firms (and countries) operate in a very different economic ecosystem that may force rapid adjustment. While corporate law evolved gradually since World War II in most Western jurisdictions, COVID-19 may trigger leaps around the world that set the corporate governance trajectory for the long run. In particular, the pro-shareholder trends of the past decades will likely be eroded in favor of other structures that are more likely to survive difficult times.

The other lesson is that corporate law is contingent on the larger social and economic environment. As Mark Roe wrote in 2003, "[b]efore a nation can produce, it must achieve social peace. ${ }^{, 26}$ While Roe was referring to the structures emerging in Europe and Japan after World War II as a result of political turmoil, the socio-economic fallout of the pandemic may result in new corporate structures that may not necessarily be efficient in the sense of creating a global optimum. In the context of the current crisis, they will likely help to address social issues, thus paving a hopeful way for long-term development. Corporate governance, however, will not remain as it used to be.

This Article proceeds as follows. Part II surveys the economic impact of the COVID19 pandemic. Part III summarizes comparative corporate governance developments since the middle of the 20th century, arguing that critical historical junctures set the scene for corporate governance until today. Part IV - the core of this paper-looks at three likely effects of the current crisis. First, we argue that corporations will have to develop more resilient (as opposed to traditionally "efficient") structures to thrive. Second, we argue that nationalism is already returning to corporate governance, thus resulting in more closed markets. Third, corporate law will move away from a shareholder primacy position and embrace stakeholder and public policy concerns to a greater degree. Finally, Part V explores how COVID-19 may affect the political economy, evolutionary dynamics, and international convergence in corporate governance. Part VI summarizes and concludes.

23. Infra notes $416-420$ and accompanying text.

24. Niles Eldredge \& S. J. Gould, Punctuated Equilibria: An Alternative to Phyletic Gradualism, in Models IN PALEOBIOLOGY 82, 83-84 (Thomas J.M. Schopf ed., 1972).

25. Regarding memetic evolution, see Richard DaWkins, THE SElFish GenE: 40TH ANNIVERSARY EDITION 245 (2016).

26. Mark J. Roe, Political Determinants of Corporate Governance 1 (2003). 


\section{COVID-19 AND ITS ECONOMIC IMPACT}

\section{A. COVID-19}

The new Coronavirus (SARS-CoV-2) causes an infectious disease that was first diagnosed in Wuhan, China, in December 2019. ${ }^{27}$ The majority of those infected with COVID19 only develop mild symptoms such as fever, cough, difficulty breathing, and tiredness, as well as loss of smell and taste, rashes, and other diffuse symptoms. ${ }^{28}$ Depending on age and prevalence, COVID-19 can also lead to acute complications such as organ failure, cytokine loads, blood clots, and septic shock. ${ }^{29}$ Pre-existing conditions, such as obesity and diabetes, as well as the general status of the immune system, are crucial determinants as to whether the new coronavirus is of severe danger to the individual. ${ }^{30}$ Prevention and holistic medicine play an important role in whether the disease turns out to follow a mild or severe symptom trajectory. ${ }^{31}$

In January 2020, the World Health Organization declared a state of emergency with international relevance over COVID-19, and in March 2020 the outbreak of a global pandemic. ${ }^{32}$ As of the beginning of 2021, almost 90 million infected cases are known and almost two million deaths have been recorded in over 215 countries in all six World Health Organization territories. ${ }^{33}$ Exponentially growing numbers of infections, the lack of a complete cure so far, and recurrent infection patterns project that there may not be a fast end to the crisis in the near future. ${ }^{34}$ With the emergency authorization of a number of apparently effective medicines in late 2020 and early 2021, a mitigation of the healthcare crisis may finally be within reach, while the economic long-term impact and the corporate governance legacy are yet to be determined.

\section{B. Economic Losses Resulting from COVID-19}

In the decade prior to COVID, globalization slowed. From 2010 on, a trend called "slowbalization" depicted stagnant or declining international trade, finance, and profits abroad. ${ }^{35}$ As the internet online window to the world shed light on production conditions abroad, in many developed jurisdictions firms felt increasingly compelled by political pressure to re-shore production and localize global value chains. ${ }^{36}$ Contagion risks became

27. Timeline: WHO's COVID-19 Response, WHO, https://www.who.int/emergencies/diseases/novel-coronavirus-2019/interactive-timeline [https://perma.cc/967K-V5UJ].

28. Symptoms of Coronavirus, CTRS. FOR DisEASE CONTROL \& PREVENTION (Feb. 22, 2021), https://www.cdc.gov/coronavirus/2019-ncov/symptoms-testing/symptoms.html [https://perma.cc/YJM7-2EQD].

29. Id.

30. Salzburg Declaration, supra note 13.

31. $I d$.

32. Timeline: WHO's COVID-19 Response, supra note 27.

33. Sachs et al., supra note 2, at 454; Coronavirus Cases, supra note 1.

34. UN Response to COVID-19, UNITED NATIONS, https://www.un.org/en/coronavirus/UN-response [https://perma.cc/ST7P-X424].

35. The Steam Has Gone out of Globalisation, ECONOMIST (Jan. 24, 2019), https://www.economist.com/leaders/2019/01/24/the-steam-has-gone-out-of-globalisation [https://perma.cc/9LBA-4PGV].

36. Multinational Companies Are Adjusting to Shorter Supply Chains, ECONOMIST (July 11, 2019), https://www.economist.com/special-report/2019/07/11/multinational-companies-are-adjusting-to-shorter-supply-chains [https://perma.cc/U3R7-N3T5]. 
apparent as shadows of the invisible hand - as vividly outlined in the 2008-09 world financial recession financial spill-overs, food insecurity emerging out of commodity prices' international interdependence and global health safety risks in spreading diseases in an increasingly mobile general population. ${ }^{37}$ Since 2016 , nationalism emerged in homelandfirst and EU-exit sentiments. ${ }^{38}$ The ongoing coronavirus-crisis exacerbated these trends of slowing globalization by putting an abrupt halt to global mobility and migration. ${ }^{39}$

The COVID-19 crisis represents the most unforeseen external shock for modern humankind, which has further slowed globalization. Starting from the beginning of 2020, the novel coronavirus caused a dramatic downturn for general mobility and international tourism including gastronomy. ${ }^{40}$ In April 2020, more than half the world's population resided in countries enforcing lockdowns, which disrupted individual lives, business activities, and international mobility. ${ }^{41}$ These lockdowns led to a slump in general consumption and reduced trade by an estimated $10 \% .^{42}$ In the first half of 2020 , global foreign direct investments were down $49 \%$, even around $75 \%$ suppressed in the developed world. ${ }^{43}$ The global economy is estimated to have contracted by $4.3 \%$ in 2020 , which is six times the economic magnitude of the 2008-09 world recession. ${ }^{44}$ Overall, the suppression of human social interaction in all major world economies spilled over into an economic decline around the globe comparable to the onset of the Great Depression. ${ }^{45}$ Current forecasts suggest that the COVID-19 global recession will be the deepest since World War II, with the largest fraction of economies experiencing declines in per capita output since $1870 .^{46}$

But what differed from previous financial turmoil and economic crises was the fact

37. Miguel Angel Centeno et al., Global Systemic Risk: Proposal for a Research Community (Apr. 1, 2013) (Princeton Inst. Int'l and Reg'1 Stud. Working Paper, 2013) (on file with authors).

38. Sofia Profita, Slowbalization and Its Risks (2019) (Columbia Univ. Working Paper) (on file with authors).

39. Julia Margarete Puaschunder, Artificial Intelligence Market Disruption, RsCH. Ass'N INTERDISC. Stud. CONF. PROC.: 13TH InT'L RAIS CONF. ON SOC. SCI. \& Humans. 1 (June 2019), http://rais.education/wpcontent/uploads/2019/07/01-JP.pdf [https://perma.cc/QHD2-DZMG].

40. Julia Margarete Puaschunder et al., COVID-19 Shock: Socio-Technical, Legal, Corporate, Economic and Governance Changes, RSCH. Ass'N INTERDISC. STUD. CONF. PROC.: 18TH INT'L RSCH. Ass'N INTERDISC. Stud. CONF. ON SOC. SCI. \& Humanities 5 (Aug. 22, 2020); see generally Stefan Gössling et al., Pandemics, Tourism and Global Change: A Rapid Assessment of COVID-19, 29 J. SUSTAINABLE TOURISM 2 (2020).

41. Policy Responses to COVID-19, INT'L MONETARY Fund, https://www.imf.org/en/Topics/imf-andcovid19/Policy-Responses-to-COVID-19 [https://perma.cc/M9NK-YKQJ].

42. Changing Places, ECONOMIST (Oct. 8, 2020), https://www.economist.com/special-report/2020/10/08/changing-places [https://perma.cc/2AEQ-3SWK].

43. Investment Trends Monitor, United NATIONS CONF. ON TRADE \& Dev. 1 (Oct. 2020), https://unctad.org/system/files/official-document/diaeiainf2020d4_en.pdf [https://perma.cc/448D-X5YE].

44. GLOBAL OUTLOOK, WORLD BANK 3 (Jan. 2021), https://openknowledge.worldbank.org/bitstream/handle/10986/34710/9781464816123-Ch01.pdf [https://perma.cc/PY4E-4W3N].

45. Sachs et al., supra note 2, at 455; see also How COVID-19 Is Changing the World: A Statistical Perspective, United NATIONS CONF. ON TRADE \& DEV. COMM. FOR COORDINATION OF STAT. ACTIVITIES 14-31 (2020), https://unstats.un.org/unsd/ccsa/documents/covid19-report-ccsa.pdf [https://perma.cc/K7LQ-NFSR] (demonstrating the economic decline in various industries).

46. Ayhan Kose \& Naotaka Sugawara, Understanding the Depth of the 2020 Global Recession in 5 Charts, WORLD BANK (June 15, 2020), https://blogs.worldbank.org/opendata/understanding-depth-2020-global-recession-5-charts [https://perma.cc/JH6L-G6XS]. 
that the economic fallout was not caused by financial constraints and economic fundamentals, but came out of an external shock that caused "social volatility" - the collective mood about a pandemic hitting humankind. ${ }^{47}$ What also differed was the fact that there was unprecedentedly clear inequality in individual preconditions and work parameters shaping the outcome in meeting the crisis that divided the market in winning and losing individuals, industries, and nations. ${ }^{48}$ To this day, the crisis appears to widen the gap between financial market performance and real economy liquidity constraints.

As for the economic fallout in the wake of "social distancing" measures, consumption decreased by $46 \%$ in China, $97 \%$ in Germany, and $20 \%$ in the United States, as well as $78 \%$ in Great Britain. ${ }^{49}$ The Financial Times Stock Exchange Group, Dow Jones Industrial Average, and Nikkei plummeted in the first quarter of 2020 drastically. ${ }^{50}$ Unemployment increased up to $70 \%$ in the mid-career segment. ${ }^{51}$ Forty million European workers were sent on short-time work. ${ }^{52}$ For example, unemployment rose in Germany from $3.2 \%$ to only $3.9 \%$ thanks to widespread Kurzarbeit labor protection plans, which encouraged firms to reduce work hours instead of laying off or furloughing workers. ${ }^{53}$ In more market-oriented territories, the impact was more severe. ${ }^{54}$ For example, in Great Britain unemployment jumped from $3.8 \%$ to $5.4 \%$, and in the United States from $3.7 \%$ to $8.9 \% .{ }^{55}$ According to the OECD and Bloomberg, $19 \%$ of workers were furloughed in Great Britain, $23 \%$ in Germany and $41 \%$ in France. ${ }^{56}$ The general world economic output fell by $3-5 \% .{ }^{57}$ Rising

47. Sianne Ngai, Theory of THE GimmicK: Aesthetic Judgment And Capitalist Form 170 (2020); A Crisis Like No Other, an Uncertain Recovery, INT'L MONETARY Fund (June 2020), https://www.imf.org/en/Publications/WEO/Issues/2020/06/24/WEOUpdateJune2020 [https://perma.cc/ZTV8$87 \mathrm{CH}$ ]; Benjamin Lee, Volatility, in RouTLEdGE HANDBOOK OF CRITICAL FinANCE STUdies 46, 54-68 (Christian Borch \& Robert Wosnitzer eds. 2020).

48. Alvaro Espitia et al., Database on COVID-19 Trade Flows and Policies, World BANK (Apr. 2, 2020), https://www.worldbank.org/en/data/interactive/2020/04/02/database-on-coronavirus-covid-19-trade-flows-andpolicies [https://perma.cc/VTD8-WD7R]; see generally WORLD BANK, GLOBAL ECONOMIC PROSPECTS (2020), https://www.worldbank.org/en/publication/global-economic-prospects [https://perma.cc/DA3G-Z9DV] (predicting the economic consequences of COVID-19).

49. Lora Jones et al., Coronavirus: How the Pandemic Has Changed the World Economy, BBC NEws (Feb. 27, 2020), https://www.bbc.com/news/business-51706225 [https://perma.cc/2DRP-HJJ5].

50. $I d$.

51. The Peril and the Promise, ECONOMIST (Oct. 8, 2020), https://www.economist.com/special-report/2020/10/08/the-peril-and-the-promise [https://perma.cc/V3RS-32BW].

52. The Pandemic Has Caused the World's Economies to Diverge, ECONOMIST (Oct. 8, 2020), https://www.economist.com/leaders/2020/10/08/the-pandemic-has-caused-the-worlds-economies-to-diverge [https://perma.cc/9N55-B96G].

53. Jones et al., supra note 49 (graphically showing data provided by the International Monetary Fund).

54. See Economy, EUROSTAT, https://ec.europa.eu/eurostat/web/covid-19/economy [https://perma.cc/8U98-BDG7] (tracking several indicia of economic health for several European countries as against the EU as a whole).

55. Jones et al., supra note 49; Cong. Rsch. SeRV., Covid-19: MEASURING UnEMPloyment, IN11456 (2020).

56. Jones et al., supra note 49 (showing data provided by the OECD); OECD Economic Outlook, ORG. ECON. COOP. \& DEV. (2020), https://doi.org/10.1787/16097408 [https://perma.cc/U2MW-ZDP7]; see also Ken Mayhaw \& Paul Anand, COVID-19 and the UK Labour Market, 36 OXFORD REV. ECON. POL'Y S215, S217-21 (2020) (surveying furlough schemes in the United Kingdom and Germany).

57. The International Monetary Fund (IMF) downgraded the decline in global gross domestic product from $-3 \%$ in April, 2020, to $-4.9 \%$ in June 2020. INT'L MONETARY FunD, supra note 47. 
poverty levels put an additional 150 million children at risk worldwide. ${ }^{58}$ The 2021 global growth is projected at $5.2 \%$, which leaves the 2021 GDP some 6.5 percentage points lower than in the pre-COVID-19 projections of January $2020 .{ }^{59}$ A shock seems to end globalization and international exchange if considering the World Bank expecting the sharpest decline in remittances in recent world history. ${ }^{60}$ All these measures resemble the onset of a lasting crisis ${ }^{61}$ with potential for fundamental system reset, ${ }^{62}$ which- together with subsequent events-will change the corporate governance structure and conduct dramatically, unprecedentedly, and lastingly. ${ }^{63}$

\section{Economic Shifts in the Wake of COVID-19}

At the same time, COVID-19 has also perpetuated the online tech world. Physically distant, we came closer digitally than ever before. Worldwide data traffic exploded on a flat digital globe. Contrary to the counter-globalization trends of the past, one area that grew globally and exponentially since 2010 is digitalized data transfer. ${ }^{64}$ In the decade prior to COVID-19, an already ongoing digitalization disruption heralded as "big data" allowed a set of innovative firms, including social media, online commercial platforms, and search engines to reap skyrocketing profits that often remain untaxed. ${ }^{65}$ These economic gains are concentrated in areas such as big data hoarding, the sale of behavioral data about consumers, and targeting online audiences with customized advertisement. ${ }^{66}$

In contrast to earlier system-inherent economic turmoil resulting in financial sector induced liquidity constraints, the external COVID shock caused "social volatility"-a collectively depressed mood that largely dampened consumption. The difference to previous systemic recessions can be seen in the rapid recovery of well-managed financial fundsfor example, the S\&P 500 recovered 50\% of its pre-COVID value within the first three months after the crisis and reached an all-time high in August 2020. Deutsche Bank recorded rising earnings during the ongoing coronavirus crisis, with its investment bank branch leading with $43 \%$ or 2.4 billion euros revenue. ${ }^{67}$ The clear distinction between

58. Press Release, UNICEF, 150 Million Additional Children Plunged into Poverty Due to COVID-19, UNICEF, Save the Children Say (Sept. 16, 2020), https://www.unicef.org/press-releases/150-million-additionalchildren-plunged-poverty-due-covid-19-unicef-save-children [https://perma.cc/PEZ3-DPSD].

59. Int'L Monetary Fund, Global Financial Stability RePORT: BRidge to ReCOVERy 1 (2020), https://www.imf.org/en/Publications/GFSR [https://perma.cc/3L8W-274K].

60. Press Release, World Bank, World Bank Predicts Sharpest Decline of Remittances in Recent History (Apr. 22, 2020), https://www.worldbank.org/en/news/press-release/2020/04/22/world-bank-predicts-sharpestdecline-of-remittances-in-recent-history [https://perma.cc/6U2M-JLK4].

61. INT'L MONETARY FUND, supra note 47.

62. The Great Reset: A Unique Twin Summit to Begin 2021, WorLd ECON. F. (June 3, 2020), https://www.weforum.org/press/2020/06/the-great-reset-a-unique-twin-summit-to-begin-2021/ [https://perma.cc/V9XZ-A79U].

63. Sachs et al., supra note 2, at 454.

64. The Steam Has Gone out of Globalisation, supra note 35.

65. Julia M. Puaschunder, Revising Growth Theory in the Artificial Age: Putty and Clay Labor, 8 ARCHIVES Bus. RSCH. 65, 77 (2020).

66. Julia M. Puaschunder, Nudging in the Digital Big Data Era, 4 EuR. J. ECON. L. \& POL. 18, 20 (2017); Julia M. Puaschunder, Nudgital: Critique of a Behavioral Political Economy, 5 ARCHIVEs Bus. RsCH. 54, 57-59 (2017).

67. Deutsche Bank überrascht mit hohem Gewinn [Deutsche Bank Surprises with High Profit], DW.COM 
COVID-19 profit and loss industries made it possible for today's highly flexible financial world to exchange underperforming market segments - such as oil, public transport, and aviation, face-to-face service sectors such as international hospitality and gastronomywith outperforming market options - such as pharmaceuticals and emergency devices for healthcare, digital technologies, fintech, artificial intelligence, and big data analytics industries, online retail, automotive and interior design and architecture.

COVID-19 now not only created significant health and security risks, social discrimination, and economic costs, but also brought about unanticipated opportunities. Industries profiting economically from the pandemic are comprised of hygiene, pharmaceuticals, and the medical professions. ${ }^{68}$ From an economic perspective, COVID-19 is an external shock that has accelerated ongoing digitalization trends. ${ }^{69}$ Because of widespread lockdowns, "social distancing" and increased home office work in many industries, social scientists have observed a more widespread acceptance for instant communication tools, social engagement, and entertainment platforms. ${ }^{70}$ We can thus say that certain firms and industries have benefited from the pandemic while many others have suffered from the expenses and burdens of COVID-19. ${ }^{71}$ Traditional small businesses appear to be particularly vulnerable. $^{72}$

Most of these trends are likely to continue in post-COVID economies, where hygiene and healthcare will further advance as healthier workers around the world will have a competitive advantage. ${ }^{73}$ The overall health status of employers will become a precious asset for determining the individual prevalence for a mild or severe COVID disease trajectory.

(Oct. 28, 2020), https://www.dw.com/de/deutsche-bank-\%C3\%BCberrascht-mit-hohem-gewinn/a-55417971 [https://perma.cc/UP6M-5V88].

68. Sharon Lerner, Big Pharma Prepares to Profit from the Coronavirus: Pharmaceutical Companies View the Coronavirus Pandemic as a Once-in-a-Lifetime Business Opportunity, INTERCEPT (Mar. 13, 2020, 1:46 PM), https://theintercept.com/2020/03/13/big-pharma-drug-pricing-coronavirus-profits [https://perma.cc/9ZQUK4GD]; Gaurav Agrawal et al., Winning Against COVID-19: The Implications for Biopharma, MCKINSEY \& Co. (Apr. 15, 2020), https://www.mckinsey.com/industries/pharmaceuticals-and-medical-products/our-insights/winning-against-covid-19-the-implications-for-biopharma\#the-implications-for-biopharma [https://perma.cc/V8TE$\mathrm{PP} 4 \mathrm{Q}]$.

69. Puaschunder, supra note 65, at 77.

70. Titus Corlatean, Risk, Discrimination and Opportunities for Education During the Times of COVID-19 Pandemic, RAIS CONF. PROCEEDINGS: 17Th INT'L RAIS CONF. ON SOC. SCI. \& HuMANITIES 37 (June 2020), http://rais.education/wp-content/uploads/2020/06/004TC.pdf [https://perma.cc/RF27-VQ8B].

71. Infra notes $81-82$ and accompanying text (discussing human capital and the value of a healthy labor force).

72. Alexander W. Bartik et al., How Are Small Businesses Adjusting to COVID-19? Early Evidence from a Survey (Nat'l Bureau of Econ. Rsch., Working Paper No. 26989, 2020); Lisa Price, Impact of COVID-19 on Small Businesses-Where Is It Worst?, SMALL BuS. TRENDS (Apr. 29, 2020), https://smallbiztrends.com/2020/04/impact-of-coronavirus-on-small-businesses.html [https://perma.cc/LQK7-8X26]; André Dua et al., Which Small Businesses Are Most Vulnerable to COVID-19-And When, MCKINSEY \& Co. (June 18, 2020), https://www.mckinsey.com/featured-insights/americas/which-small-businesses-are-most-vulnerable-tocovid-19-and-when [https://perma.cc/6L9S-L64S]; see also James Kwak, The End of Small Business, WASH. POST (July 9, 2020), https://www.washingtonpost.com/outlook/2020/07/09/after-covid-19-giant-corporationschains-may-be-only-ones-left/?arc404=true [https://perma.cc/WW99-EEDW] (suggesting that the post-pandemic economy will be dominated by giant corporations).

73. The Great Reset, supra note 62 (discussing trends of using health information in the workplace). 
For another, the individual health conscientiousness will influence the likelihood of becoming a "superspreader" at work. Employees that already had the novel coronavirus may have acquired some degree of immunity and may be in a more advantageous position to perform unhindered in the workspace, as will those who have been vaccinated. Elderly and chronically ill patients' passing, and vulnerabilities risks already now change labor market demand towards favoring young, healthier and corona-survivors, who may benefit from a natural immunity and being more virus-resistant. ${ }^{74}$

Employers may be more interested in what category their workforce may fall to plan workplace safety precaution measures when building healthy working conditions. ${ }^{75}$ More than ever before in the history of modern workforce do employers nowadays care about the overall well-being and physical interaction of their labor cadre in a hygienic environment. Respective preventive medical care of the workforce and community-building around monitoring of one's own and others' health but also group learning how to enhance hygiene in teams will gain more attention in the COVID-19-struck workplace and will have lasting changes enacted. ${ }^{76}$

In light of social distancing mandates and with the growth of scientific evidence derived from algorithms and big data, workers with better access to internet connectivity and AI-human-compatibility (i.e., computer and AI literacy, and related skills) have growing competitive advantages. ${ }^{77}$ It may also become a matter of survival for large organizations to understand the health of their workers with the help of these novel technologies. On the one hand, employers will need to estimate whether workplace conditions are likely to produce mass outbreaks - such as the ones that, for instance, occurred in the meatpacking industry or luxury tourism cruise ships in several countries. ${ }^{78}$ On the other hand, and maybe less benignly, employers will want to know whether workers' medical histories, genetic profiles, living arrangements and social habits are likely to result in COVID-19 infection risks and predict trajectory likelihoods based on genetic prevalence derived from big data analyses. With the entry of AI algorithms and insights derived from large data sets in the medical field, ${ }^{79}$ they may hope to maintain a healthy workforce through encouraging workers' self-monitoring, while also pro-actively caring for safety through mobile tracking of

74. Michael Papadopoulos et al., Older Workers Report: Over Half of Unemployed Older Workers at Risk of Involuntary Retirement, SCHWARTZ CTR. FOR ECON. POL'Y ANALYSIS (Aug. 5, 2020), https://www.economicpolicyresearch.org/jobs-report/over-half-of-older-workers-unemployed-at-risk-of-involuntary-retirement [https://perma.cc/DA2N-7ZDH].

75. See generally ECOWELLNESS GRP., supra note 12 (emphasizing the need to for employers to ensure their workers' health).

76. See infra Section IV.A.3 (discussing possible corporate governance consequences).

77. Puaschunder, Nudgital: Critique of a Behavioral Political Economy, supra note 66, at 79 .

78. On the meatpacking industry, see, for example, Victoria Foster, Is Eating Meat from Meatpacking Plants with Covid-19 Coronavirus Outbreaks Safe?, Forbes MAG. (June 21, 2020, 3:40 PM), https://www.forbes.com/sites/victoriaforster/2020/06/21/is-eating-meat-from-meatpacking-plants-with-covid19-coronavirus-outbreaks-safe/?sh=5d2d5bcb7089 [https://perma.cc/E7KR-H5VL] (discussing outbreaks both in the United States and Germany); on cruise ships, see, for example, Christopher Elliott, When Will It Be Safe to Cruise Again? These Signs That Will Help You Decide When to Sail, USA TODAY (Feb. 5, 2021), https://www.usatoday.com/story/travel/advice/2021/02/05/covid-when-will-it-be-safe-to-cruise/4386762001 [https://perma.cc/KL3F-DLZY].

79. See generally Julia M. Puaschunder \& Martin Gelter, The Social Representations and Legal Theory of Artificial Intelligence, Robotics and Big Data in Healthcare (June 11, 2020) (unpublished manuscript), available 
infected as a means of crowd control, as well as potentially through the use of predictive algorithms. Much like many employers require drug tests at the hiring stage or periodically, they may seek to use digitalization tools to predict health statuses and working conditions' outcomes to reduce the risk of being put out of business or severely harmed by a COVID19 outbreak.

Arguably, firms that are better able to use technology to determine and track employees' health status will be the winners in the post-pandemic market. It may be too early to say whether nimble startups and other small- and medium-sized firms will be more likely to succeed, or whether large corporate behemoths with access to large datasets will be more likely to thrive. Already, however, it is becoming apparent that these novel digitalization opportunities come with the price of a heightened responsibility to protect privacy in retrieving big data inference, ensure access to information and healthcare democratically, secure individuals from discrimination against health status propensities, and back those who are naturally hindered to compete in markets financially and socially. ${ }^{80}$

\section{COMPARATIVE CORPORATE GOVERNANCE: CRISIS AS A DETERMINANT AND ACCELERATOR OF LONG-TERM TRENDS}

As we have seen, certain industries suffered from the economic lockdown because their products or services could not be effectively sold or offered during the lockdown, for example, the hospitality, tourism, and retail industries, and many parts of the service sector. ${ }^{81}$ Others benefited greatly from increased demand under the given circumstances, such as hygiene product providers, social online media platforms, and online retailers. ${ }^{82}$ These effects will continue as the pandemic persists and will reshape economic structures in the years to come, with some industries ceasing to exist or shrinking in size, and others expanding.

However, from the perspective of corporate governance, two other questions loom. First, is COVID-19 likely to alter which types of corporate governance structures are conducive to a firm's survival and success? In other words, given that any corporate governance choice involves different costs and benefits, will the tradeoffs firms have to make in

at https://ssrn.com/abstract=3603106 (discussing a survey on the intersection of these sectors).

80. Julia M. Puaschunder, et al., Alleviating an Unequal COVID-19 World: Globally Digital and Productively Healthy (Fordham L. Legal Studs., Working Paper No. 3679351, 2020), https://ssrn.com/abstract=3679351.

81. E.g., Neeraj Kumar \& Danny Haydon, Industries Most and Least Impacted by COVID-19 from a Probability of Default Perspective-March 2020 Update, S\&P Glob. MкT. InTEL. (Apr. 7, 2020), https://www.spglobal.com/marketintelligence/en/news-insights/blog/industries-most-and-least-impacted-bycovid-19-from-a-probability-of-default-perspective-march-2020-update [https://perma.cc/UG62-FZZJ] (detailing industries most impacted by COVID-19); Darren Dodd, COVID 19's Corporate Casualties, FIN. TIMES (June 22, 2020), https://www.ft.com/content/eb6efc36-bf99-4086-a98a-7d121738b4b4 [https://perma.cc/88DRMHCS].

82. E.g., Jason Aravanis, Five Industries Set to Outperform Due to COVID-19, IBISWORLD (Apr. 7, 2020), https://www.ibisworld.com/industry-insider/coronavirus-insights/five-industries-set-to-outperform-due-tocovid-19/ [https://perma.cc/ZW3C-YM2X] (giving examples of industries that will benefit from COVID-19); Rohit Arora, Which Companies Did Well During the Coronavirus Pandemic?, FoRBES (June 30, 2020), https:// /2020/06/30/which-companies-did-well www.forbes.com/sites/rohitarora -during-the-coronavirus-pandemic/\#17fe6c9b7409 [https://perma.cc/7K99-QKCB] (providing examples of companies that performed well during COVID-19). 
corporate governance change? This question is not only significant in a descriptive manner, but also because it may help derive recommendations for firms on how to adjust.

Second, are we likely to see long-term changes in country-level corporate governance structures? Again, any laws or regulations concerning corporate governance inevitably involve tradeoffs. COVID-19 may change which laws are desirable. In order to enable firms to succeed, both domestically and in international competition, new legal frameworks may be better suited in light of new economic, social, and political circumstances. Thus, to compete internationally, ${ }^{83}$ but also to address new political challenges, countries may move to different corporate governance laws and arrangements. This may also mean that political bargains between different interest groups may come out differently as a new outcome in the perennial struggle over the changing rents produced by a country's economy.

Idiosyncratic historical events often had a lasting impact on the institutional choices of a country, with the impact felt over decades. The major industrialized countries emerged from the turmoil of the first half of the 20th century with very different corporate governance regimes. The United States was already dominated by the "Berle-Means corporation" before the Great Depression. ${ }^{84}$ New-Deal era economic legislation helped to further entrench the structure in place at the time, in part by maintaining a financial industry characterized by comparatively small, local banks that were ill-positioned, compared to other jurisdictions, to develop into significant large shareholders. ${ }^{85}$ The 1933 Securities Act and 1934 Securities Exchange Acts sought to protect outside investors through disclosure, which helped U.S. corporate governance to retain a basic pro-shareholder orientation, even some disclosure requirements inhibited coordination by institutional investors. ${ }^{86}$

Thus, firms kept dispersed ownership structures dominated by powerful management and weak owners, in part because a large percentage of shareholders at the time were retail investors, even if they were protected by a stronger regulatory framework than in prior decades. ${ }^{87}$ Labor was kept at bay through compromises between management and unions, part of which were generous defined-benefit private pension plans providing retirement savings. These turned employees effectively into their employers' creditors and created a shared, if rather conservative, outlook to corporate wealth generation. ${ }^{88}$

83. For a discussion of the role of open markets and international competition for convergence in corporate governance, see William W. Bratton \& Joseph A. McCahery, Comparative Corporate Governance and the Theory of the Firm: The Case Against Global Cross Reference, 38 CoLum. J. TRANSNAT'L L. 213, 239-41 (1999); Hansmann \& Kraakman, supra note 11, at 450-51; Jeffrey N. Gordon \& Mark J. Roe, Introduction, in CONVERGENCE AND Persistence In CORPORATE GovernanCE, 1, 1-2, 8-9 (Jeffrey N. Gordon \& Mark J. Roe eds., 2003).

84. Adolf A. Berle, Jr. \& Gardiner C. MeAns, The Modern Corporation AND Private Property 47-68 (1932) (discussing the prevalence of dispersed ownership in 1929).

85. Mark J. Roe, Some Differences in Corporate Structure in Germany, Japan, and the United States, 102 YALE L.J. 1927, 1948-56 (1993).

86. See, e.g., Bernard S. Black, Shareholder Passivity Reexamined, 89 MICH. L. ReV. 520, 536-41 (1990); William T. Allen \& Reinier KRAakman, COMmentaries and CASES ON THE LAW OF Business ORGANIZATIONS 204 (5th ed. 2016) (both discussing the SEC's proxy rules and their effects on institutional investor activism).

87. Harwell Wells, A Long View of Shareholder Power: From the Antebellum Corporation to the TwentyFirst Century, 67 Fla. L. REv. 1033, 1074 (2015) ("In the world of the Berle-Means corporation, shareholder powerlessness was a given").

88. Martin Gelter, The Pension System and the Rise of Shareholder Primacy, 43 SETon HaLl L. Rev. 909, 
Continental European countries provide a sharp contrast to the United States in terms of the corporate governance structures in the period following World War II. Stock markets were much smaller relative to the size of the economy after World War II than in the English-speaking world. ${ }^{89}$ Depending on the country, one would see a different mix of familydominated firms (e.g., Italy), significant government ownership (e.g., France), or a strong role for local financial institutions such as banks and insurance companies (Germany). ${ }^{90}$ Firms tended to be governed by controlling shareholders or coalitions of large shareholders. ${ }^{91}$ Employees often had a significant role, which was formalized through employment and labor laws that gave significant power to unions, for example through works councils that required labor or union input on key shop-floor decisions, thus giving more bargaining power to unions. ${ }^{92}$ In some jurisdictions, most prominently Germany, labor voice in corporate governance was even more strongly formalized through employee representation on the board, ${ }^{93}$ likely in part to reduce the influence of powerful large shareholders. ${ }^{94}$

In Germany in particular, the stock market never recovered from the Great Depression, with only a relatively small number of firms being publicly traded, ${ }^{95}$ and corporate

944-46 (2015).

89. E.g., Raghuram Rajan \& Luigi Zingales, The Great Reversals: The Politics of Financial Development in the Twentieth Century, 69 J. FIN. ECON. 5, 15 (2003) (providing data on the GDP of various countries throughout the past century).

90. See, e.g., Marco Becht \& Alisa Roëll, Blockholdings in Europe: An International Comparison, 43 EuR. ECON. REV. 1049, 1050-55 (1999) (providing data on shareholding in Europe); La Porta et al., supra note 12, at 471, 492-95 (showing data about ownership structure around the world); Mara Faccio \& Larry H.P. Lang, The Ultimate Ownership of Western European Corporations, 65 J. FIN. ECON. 365, 379-80 (2002) (giving data on the breakdown of the concentration of control in various countries); PETER A. GouREvitch \& JAMES SHINN, POLITICAL POWER AND CORPORATE CONTROL 18 (2005); PEPPER D. CULPEPPER, QUIET POLITICS AND BusinesS POWER 31-32 (2011); Wolf-Georg Ringe, Changing Law and Ownership Patterns in Germany: Corporate Governance and the Erosion of Deutschland AG, 68 AM. J. COMPAR. L. 493, 496-98 (2015) (all discussing roles of financial institutions in various parts of the world).

91. E.g., Marco Becht \& Ekkehart Boehmer, Voting Control in German Corporations, 23 InT'L Rev. L. \& ECON. 1 (2003); Ekkehard Boehmer, Who Controls German Corporations?, in CORPORATE GOVERNANCE REGIMES 268 (Joseph A. McCahery et al. eds., 2002); Jeremy Edwards et al., Corporate Governance in Germany: The Role of Banks and Ownership Concentration, 15 ECON. POL'Y 239, 246-51 (2000); for Italy Marcello Bianchi \& Magda Bianco, Italian Corporate Governance in the Last 15 Years: From Pyramids to Coalitions?, (ECGI Finance Working Paper No. 140/2006, 2006), https://ssrn.com/abstract=952147; see generally RoE, supra note 26, at 16-17 (detailing differing corporate governance structures).

92. E.g., Martin Gelter, The Dark Side of Shareholder Influence: Managerial Autonomy and Stakeholder Orientation in Comparative Corporate Governance, 50 HARV. INT'L L.J. 129, 171-73 (2009) (explaining that employment protection laws in Germany and France make dismissals more expensive and improve the bargaining position of employees); Leo E. Strine, Jr., The Soviet Constitution Problem in Comparative Corporate Law: Testing the Proposition That European Corporate Law Is More Stockholder-Focused Than U.S. Corporate Law, 89 S. CAL. L. REV. 1239, 1259-61 (2016) (detailing the employee protection in Europe compared to the United States).

93. Katharina Pistor, Codetermination: A Sociopolitical Model with Governance Externalities, in EMPLOYEeS AND CORPORATE GOVERNANCE 163 (Margaret M. Blair \& Mark J. Roe eds., 1999).

94. Mariana Belloc \& Ugo Pagano, Co-Evolution of Politics and Corporate Governance, 29 INT'L REV. L. \& ECON. 106, 107-08 (2009); Gelter, supra note 92, at 181-84.

95. See, e.g., Caroline Fohlin, The History of Corporate Ownership and Control in Germany, in A HISTORY OF CORPORATE GOVERNANCE AROUND THE WORLD 223, 231-37 (Randall K. Morck ed., 2006) (discussing the small number of publicly traded firms and how retail investors exited the stock market). 
finance operating to a large degree through relationships with banks. ${ }^{96}$ Obviously, this is not to say that Germany or Continental Europe did not experience considerable economic success during the post-war decades, even relative to the United States. ${ }^{97}$ The way in which these countries did this was, however, very different, in a large part because of institutional choices taken in times of crisis. Outside investment by the general population played only a negligible role, in part because retirement income was provided by the government. ${ }^{98}$ Families, large financial groups, industrial groups, and governments served as significant shareholders. ${ }^{99}$ Labor was and is an influential interest group in many jurisdictions, ${ }^{100}$ as are relational lenders. ${ }^{101}$

Similarly, Japan embarked on a new corporate governance trajectory after World War II. While its large firms had previously been dominated by the interests of controlling family interests, these groups were broken up under the American occupation. ${ }^{102}$ The resulting corporate structure (cross-ownership groups or keiretsu) meant that firms within a conglomerate effectively controlled each other, leaving little influence for outside shareholders. ${ }^{103}$ At the same time, firms were adopting lifetime employment, meaning that a significant segment of workers would spend their entire career at the same company or within the same corporate group. ${ }^{104}$ Arguably, the political reason at the time was to reduce the risk of a swing further to the left in terms of economic policy and to appease a resurgent

96. E.g., Jeremy Edwards et al., supra note 90 (surveying ownership structures and bank influence in Germany); Brian R. Cheffins, The Metamorphosis of "Germany Inc.": The Case of Executive Pay, 49 AM. J. COMPAR. L. 497, 500 (2001) (explaining the position and power of German banks in corporate governance); Andreas Hackethal et al., Banks and German Corporate Governance: On the Way to a Capital Market-Based System?, 13 CORP. GOVERNANCE: INT'L REV. 397 (2005) (detailing further the role of German banks and corporate governance).

97. E.g., Bart van Ark \& Dirk Pilat, Productivity Levels in Germany, Japan, and the United States, 2 BROOKINGS PAPERS: MICROECONOMICS 1, 2 (1993) (showing how Germany and Japan caught up with the United States in terms of productivity).

98. GouREVITCH \& SHINN, supra note 90, at 213-28; Gelter, supra note 88, at 963-68; David S. Scharfstein, Presidential Address: Pension Policy and the Financial System, 73 J. Fin. 1463, 1468-73 (2018).

99. Bratton \& McCahery, supra note 83.

100. E.g., Lawrence A. Cunningham, Commonalities and Prescriptions in the Vertical Dimension of Global Corporate Governance, 84 CORNELL L. REV. 1133 1141-42 (1999) (providing the example of the influence of works councils in European countries); Strine, Jr., supra note 92, at 1251-54 (explaining the legal backing of employee participation in management, contrasted with legal rights only to shareholders under Delaware and other U.S. law); Gelter, supra note 92, at 171-73 (detailing the influence of works councils in Europe); Luca Enriques et al., The Basic Governance Structure: Minority Shareholders and Non-Shareholder Constituencies, in THE ANATOMY OF CORPORATE LAW 79, 89-92 (Reinier Kraakman et al. eds., 3rd. ed. 2017).

101. E.g., Erik Berglöf, A Note on the Typology of Financial Systems, in COMPaRATIVE CORPORATE GovernanCE 151, 159-64 (Klaus J. Hopt \& Eddy Wymeersch eds., 1997); Dignam \& GALANIS, supra note 4, at 64; Christian Leuz, Different Approaches to Corporate Reporting Regulation: How Jurisdictions Differ and Why, 40 ACCT. \& BUS. RsCH. 229, 236-37 (2010) (comparing outsider and relationship-based systems for lending).

102. Randall K. Morck \& Masao Nakamura, A Frog in the Well Knows Nothing of the Ocean: A History of Corporate Ownership in Japan, in HISTORY OF CORPORATE GOVERNANCE 367, 368-70 (Randall K. Morck ed, 2006).

103. Id. at 432-37.

104. Caslav Pejovic, Japanese Corporate Governance: Behind Legal Norms, 29 PENN ST. INT'L L. REv. 483,491-92 (2011); Sayuri A. Shimoda, Comment, Time to Retire: Is Lifetime Employment in Japan Still Viable?, 39 FORDHAM INT’L L.J. 753, 755-57 (2016). 
labor movement. ${ }^{105}$ Lifetime employment complemented cross-ownership in that it matched a low influence of outside investors and arguably ensured that firms were dominated by their own class of cadres. ${ }^{106}$

The point of the examples of the United States, Germany, and Japan is not that each country's firms are likely to react to COVID-19 in a certain way, but to illustrate that peculiar historical contingencies often beget long-term structures. Each of the three countries achieved a measure of economic success with them in the decades to come. Both the German and Japanese labor structures are sometimes thought to have been conducive to the development of high-skills workforces in a large-scale industrial context. ${ }^{107}$ Whatever their consequences, they were not necessarily intended for these goals, but rather put into place to address a peculiar current problem.

Historically contingent radical changes such as the ones described subsequently tend to evolve gradually during politically calmer times. During the last decades of the 20th century, multiple corporate governance systems edged toward a more shareholder-oriented system. The United States was one of the jurisdictions leading the way in its move from managerial capitalism ${ }^{108}$ to shareholder capitalism. ${ }^{109}$ Arguably, U.S. corporations began to edge toward a shareholder-oriented around 1980, in which they were pushed ahead by a

105. Ronald J. Gilson \& Mark J. Roe, Lifetime Employment: Labor Peace and the Evolution of Japanese Corporate Governance, 99 Colum. L. REv. 508, 520-23 (1999); Chiaki Moriguchi \& Hiroshi Ono, Japanese Lifetime Employment. A Century's Perspective, in Institutional ChANGE IN JAPAN 152, 159-62 (Magnus Blomström \& Sumner La Croix eds., 2006).

106. Mark J. Loewenstein, Stakeholder Protection in Germany and Japan, 76 TUL. L. Rev. 1673, 1686-88 (2002) (discussing the employee orientation of Japanese boards); Ronald J. Gilson \& Curtis J. Milhaupt, Choice as Regulatory Reform: The Case of Japanese Corporate Governance, 54 AM. J. COMPAR. L. 343, 348-49 (2005) (discussing how directors were appointed to the board as a culmination of their career with the company, and how they were expected to represent the division from which they were appointed); see also Masahiko Aoki, Toward an Economic Model of the Japanese Firm, 28 J. ECON. LITERATURE 1, 10-14 (1990) (discussing how Japanese firms use advancement to higher ranks within the firm to set incentives).

107. For Germany, see, for example, Felix FitzRoy \& Kornelius Kraft, Co-Determination, Efficiency and Productivity, 43 BRIT. J. INDUS. Rels. 233 (2005); Larry Fauver \& Michael E. Fuerst, Does Good Corporate Governance Include Employee Representation? Evidence from German Corporate Boards, 82 J. FIN. ECON. 673, 679 (2006); Gelter, supra note 92, at 169. For Japan, see, for example, Masanori Hashimoto, Bonus Payments, on-the-Job Training, and Lifetime Employment in Japan, 87 J. POL. ECON. 1086, 1089-90 (1979); Jonathan R. Macey, Firm-Specific Human Capital Investments and Hegelian Ethics: A Comment on Cornell and Posner, 11 CARDOZO L. REv. 505, 510 (1990); Ken Yamada \& Daiji Kawaguchi, The Changing and Unchanged Nature of Inequality and Seniority in Japan, 13 J. ECON. INEQ. 129, 143 (2015); but see Gilson \& Roe, supra note 105, at 514-15 (criticizing this view).

108. On managerial capitalism, see, for example, DAVID SKEEL, ICARUS IN THE BOARDROOM: THE Fundamentals IN CORPORATE AMERICA AND WHERE THEY CAME FROM 108-11 (2005); GERALD F. DAVIS, MANAGED By THE MARKETS: How FinANCE ReShaPED AMERICA 72-77 (2009); Alan Dignam \& Michael Galanis, Corporate Governance and the Importance of Macroeconomic Context, 28 OXFORD J. LEGAL STUD. 201, 222 (2008). See also Bengt Holmstrom \& Steven N. Kaplan, Corporate Governance and Merger Activity in the United States: Making Sense of the 1980s and 1990s, 15 J. ECON. PERSPS. 121, 123 (2001) (noting that even in the 1970s, "corporate governance structures ... gave the managers of the large public corporations little reason to focus on shareholder concerns").

109. E.g., Ronald J. Gilson \& Jeffrey N. Gordon, The Agency Costs of Agency Capitalism: Activist Investors and the Revaluation of Governance Rights, 113 COLUM. L. REV. 863, 874 (2013) (detailing the rise of agency capitalism); see generally Edward B. Rock, Adapting to the New Shareholder-Centric Reality, 161 U. PA. L. REV. 1907 (2013) (detailing the rise of shareholder capitalism). 
number of developments. First, hostile takeovers - from which shareholders typically benefit, arguably at the expense of other constituencies - began to shake up corporate America during this period. ${ }^{110}$ Second, on the academic level, Jensen and Meckling famously formalized agency theory in $1976,{ }^{111}$ which began to be the predominant model with which financial economists as well as legal scholars used to explain corporate governance. ${ }^{12}$ Third, business education was increasingly dominated by the objective of shareholder wealth maximization, thus influencing two generations of business leaders. ${ }^{113}$ Fourth, during the 1990s, executive compensation began to be much more strongly geared toward setting incentives to increase share value, thereby intending to align managers' interests with those of shareholders. ${ }^{114}$ Fifth, the ownership stake and influence of institutional investors in companies increased. ${ }^{115}$ Institutional retirement savings played a role in this, in part because pension plans needed to be funded, which paved the way to defined contribution plans such as 401(k)s, meaning that workers were invested in the market through institutional investors rather than expecting a pension from an employer. ${ }^{116}$ With this "reconcentration of share ownership," which continued into the 2000s, investors increasingly tended to be indirectly represented through institutions ${ }^{117}$ and commentators began to speak of a "shareholder-centric reality." 118 The Business Roundtable, a leading advocacy group of top management, announced its formal support for shareholder primacy only in

110. See Holmstrom \& Kaplan, supra note 108, at 124-26 (providing data about the prevalence of takeovers). On the theory of the market for corporate control, see Henry G. Manne, Mergers and the Market for Corporate Control, 73 J. POL. ECON. 110 (1965).

111. Michael C. Jensen \& William H. Meckling, Theory of the Firm: Managerial Behavior, Agency Costs and Ownership Structure, 3 J. FIN. ECON. 305 (1976) (proposing the theory); see also RAKESH KHURANA, FROM Higher Aims to Hired Hands: The Social TRANSFormation of AMERICAN Business SCHOOls and the Unfulfilled Promise of Management as a Profession 317-26 (2007); Justin Fox, The Myth of the RATIONAL MARKET: A History OF RISK, REWARD, AND DELUSION ON WALl STREET 160-71 (2009).

112. See, e.g., Frank H. EASTERbroOK \& DANiEl R. Fischel, The ECONOMIC Structure OF Corporate LAW 11 (1991) (explaining that a corporation will succeed when gains from division of labor exceed agency costs).

113. See KhuRAna, supra note 111 , at 297-323; see also, e.g., Gerald F. Davis, MANAGED By the MARKETS 87-93 (2009); Hansmann \& Kraakman, supra note 11, at 440-41 (all describing the replacement of the managerial system by shareholder wealth maximization).

114. See Marcel Kahan \& Edward B. Rock, How I Learned to Stop Worrying and Love the Pill: Adaptive Responses to Takeover Law, 69 U. CHI. L. REV. 871, 884, 873-74 (2002) (suggesting that executive compensation creates an incentive to bargain for a high bid price). But see Lucian Arye Bebchuk \& Jesse M. Fried, Executive Compensation as an Agency Problem, 17 J. ECON. PERSPS. 71 (2003); Lucian A. Bebchuk \& Jesse M. Fried, Pay Without Performance: Overview of the Issues, 30 J. CORP. L. 647 (2005) (both suggesting that executive compensation benefits management rather than shareholders).

115. See, e.g., Edward B. Rock, The Logic and (Uncertain) Significance of Institutional Shareholder Activism, 79 GEO. L.J. 445, 447-53 (1991) (detailing the rise of institutional shareholders); Ronald J. Gilson \& Jeffrey N. Gordon, The Rise of Agency Capitalism and the Role of Shareholder Activists in Making It Work, 31 J. APPLIED CORP. FIN. 8, 8 (2019) (explaining the conflict between agents and owners of businesses stemming from institutional investors).

116. E.g., Gelter, supra note 88, at 921-28 (providing data to demonstrate phasing out of pension plans to 401(k) plans in the United States).

117. See Gilson \& Gordon, supra note 109 , at 886-88, 915.

118. E.g., Edward B. Rock, Adapting to the New Shareholder-Centric Reality, 161 U. PA. L. REv. 1907 (2013). 
1997. ${ }^{119}$

During the 1990s and 2000s, corporate governance scholars became increasingly aware of growing "convergence" toward a shareholder or "Anglo-Saxon" model, as an aspect of globalization. ${ }^{120}$ Laws and practices increasingly prioritized the interests of outside investors in many jurisdictions. Labor issues became more and more sidelined. ${ }^{121}$ In part, this trend was owed to the rising global scope of activity of institutional investors from the English-speaking countries, as well as of the trend for multinational corporations to tap capital markets. ${ }^{122}$ Proponents of convergence theories argued that a shareholder primacy model was more efficient, meaning that firms (and countries) following it would be more successful in the increasingly global marketplace characterized by open trade and investment. International institutions - such as the World Bank or the IMF-sometimes made the provision of finance dependent on the adoption of "best practices," especially the OECD's "Principles of Corporate Governance." "23 For example, legislatures across Europe implemented reforms intended to strengthen shareholders, in particular outside investors. The European "corporate governance movement" at the time was in part characterized by the adoption of corporate governance codes following the British "comply or explain"

119. Bus. RoundtABle, STATEMENT ON CORPORATE GOVERNANCE 3 (1997).

120. E.g., Hansmann \& Kraakman, supra note 11, at 439 (emphasizing the global scope of convergence); Gordon \& Roe, supra note 83, at 1-3 (outlining the history of the convergence debate).

121. E.g., Michelle Welsh et al., The End of the 'End of History for Corporate Law'?, 2014 Australian J. CORP. L. 147, 157-59 (emphasizing the narrow shareholder focus of the convergence debate); Martin Gelter, Corporate Governance: Old and New, in UNDERSTANDING THE COMPANY: CORPORATE GOVERNANCE AND THEORY 37, 54-55 (Barnali Choudhury \& Martin Petrin eds., 2017); see also John Tagliabue, Resisting Those Ugly Americans: Contempt in France for U.S. Funds and Investors, N.Y. TIMES, Jan. 9, 2000 (quoting French president Jacques Chirac on French workers "being asked to sacrifice simply to "safeguard the investment benefits of Scottish widows and California pensioners"').

122. Jeffrey N. Gordon, Convergence and Persistence in Corporate Law and Governance, in THE OXFORD HANDBOOK OF CORPORATE LAW AND GOVERNANCE 28, 28 (Jeffrey N. Gordon \& Wolf-Georg Ringe eds., 2018) (discussing how the convergence-persistence question is linked to the comparative advantage of corporate governance in global product markets and global capital markets).

123. See MAthias M. Siems, ConVERgENCE In Shareholder Law 241-42 (2008) (noting that the IMF and World Bank use OECD Principles when deciding to make loans); DIGNAM \& GALANIS, supra note 4, at 14243; Ozden Deniz, The Importance of Corporate Governance for a Well-Functioning Financial System: Reforming Corporate Governance in Developing Countries, 14 DuQ. Bus. L.J. 219, 226 (2012) (noting that IMF and World Bank consider these principles "best practices"); Gordon, supra note 122, at 32 (remarking that both the IMF and World Bank were concerned with corporate governance reform); see also Craig Ehrlich \& Dae-Seob Kang, U.S. Style Corporate Governance in Korea's Largest Companies, 18 UCLA PAC. BASIN L.J. 1, 28-29 (2000) (discussing the World Bank and IMF making financial packages for South Korea conditional on the adoption of certain corporate governance reforms); Zehra G. Kavame Eroglu, The Political Economy of International Standard Setting in Financial Reporting: How the United States Led the Adoption of IFRS Across the World, 37 Nw. J. INT'L L. \& BUS. 457, 500 (2017) (discussing pressure from the World Bank and IMF to adopt International Financial Reporting Standards). 
model. ${ }^{124}$ In addition, many countries introduced pro-shareholder reforms, such as the German Control and Transparency Act of 1998, ${ }^{125}$ the French "Nouvelles régulations économiques" of 2001, ${ }^{126}$ and the Italian reforms of 2004. ${ }^{127}$ The EU Commission's "High Level Report of Company Law Experts" of $2002^{128}$ promoted a shareholder agenda, which was reflected in the 2007 Shareholder Rights Directive. ${ }^{129}$ With this trend paralleled in many parts of the world, Hansmann and Kraakman were famously able to identify the ascendancy of the shareholder model in corporate governance as the key piece to international convergence in 2001, arguably because it was most efficient. ${ }^{130}$

In addition, in recent years studies have found that firms are increasingly owned in part by the same set of institutional investors around the world. Retail investors and locally entrenched elites have been losing ground against mutual funds, hedge funds, and increasingly passively managed index funds. That is not to say, however, that ownership structures are the same around the world. Large and controlling shareholders persist where they were before, but only to a slightly smaller degree. ${ }^{131}$

The 2008-09 financial crisis did not lead to an initial rejection of the shareholder model or a reversal of the convergence phenomenon. To the contrary, policymakers and scholars around the world initially seemed to consider stronger shareholder power as part of the cocktail of instruments to address the pathologies brought to light by the financial crisis. The best case in point may be shareholder "say on pay" as an instrument to rein in runaway executive compensation. Following the U.K. model, ${ }^{132}$ many countries, including the United States, adopted mandatory (but not necessarily binding) votes on executive compensation. ${ }^{133}$ This may be in part linked to the idea that institutional investors of various

124. Ruth V. Aguilera \& Alvaro Cuervo-Cazurra, Codes of Good Governance, 17 CORP. GOVERNANCE: INT'L REV. 376, 377-79 (2009).

125. Gesetz zur Kontrolle und Transparenz im Unternehmensbereich [Law on Control and Transparency in the Corporate Sector] (KonTraG), 30 April 1998, BGBL I at 786. E.g., Ulrich Seibert, Control and Transparency in Business (KonTraG): Corporate Governance Reform in Germany, 10 EUR. BuS. L. REV. 70,70 (1999).

126. Loi 2001-420 du 15 mai 2001 relative aux nouvelles regulations économiques [Law 2001-420 of May 15, 2001 on New Economic Regulations], JouRnAL OFFICIEL DE LA RÉPUBLIQUE FranÇAISE [J.O.]; see Ben Clift, French Corporate Governance in the New Global Economy: Mechanisms of Change and Hybridisation within Models of Capitalism, 55 POL. STUD. 546, 553-57 (2007) (explaining how the French government has taken a quasi-dirigiste [quasi-control of economic and social matters] approach by re-regulating French corporate governance and financial markets).

127. See also Luca Enriques \& Paolo Volpin, Corporate Governance Reforms in Continental Europe, $21 \mathrm{~J}$. ECON. PERSPS. 117, 127-37 (2007) (detailing the corporate governance reforms in France, Germany, and Italy).

128. The High LeVel Group of COMPANy LAw EXPERTs, RePORT ON A MODERN FramewORK FOR COMPANY LAW IN EUROPE (2002).

129. Directive 2007/36/EC of the European Parliament and of the Council of 11 July 2007 on the Exercise of Certain Rights of Shareholders in Listed Companies, 2007 O.J. No. L184/17 (implementing e.g., a record date system and facilitating voting for international investors).

130. Hansmann \& Kraakman, supra note 11, at 439.

131. For recent corporate ownership data, see ADRIANA DE LA CRUZ ET AL., OWNERS OF THE WORLD'S LisTED COMPANIES (OECD CAPITAL MARKET SERIES 2019), http://www.oecd.org/corporate/Owners-of-theWorlds-Listed-Companies.htm [https://perma.cc/7DAS-G2SY]; Gur Aminadav \& Elias Papaioannou, Corporate Control Around the World, 75 J. FIN. 1191, 1205-08 (2020).

132. Companies Act 2006, § 439 (UK).

133. For the United States, see Dodd-Frank Wall Street Reform and Consumer Protection Act, Pub. L. No. 111-203, § 951, 124 Stat. 1376 (2010); for the EU, see Directive 2017/828, of the European Parliament and of the 
types would increasingly be well-positioned to monitor management (or controlling shareholders). The idea of "shareholder stewardship" got traction in the 2010s, and many countries introduced a stewardship code following the model of the United Kingdom. These codes are intended to ensure a beneficial impact of institutional investors on firms. ${ }^{134}$ However, during the 2010s, a countervailing tendency emerged against the trend favoring outside equity investors. Examples, which we will address in more depth below, include the increasing growth of "loyalty shares" in some European countries as an anti-takeover device, ${ }^{135}$ or a growing attractiveness of increased labor power in corporate governance, albeit surprisingly in arguably shareholder-oriented jurisdictions such as the United Kingdom and the United States. ${ }^{136}$

The history of corporate governance in the 20th century illustrates two types of corporate governance changes. First, deep structural roots were set in the aftermath of the crisis brought by the Depression and World War II. Different jurisdictions had to deal with political issues in a variety of ways, which were intended to address a problem at hand but created the tracks for long-term development. Along the way, jurisdictions proceeding within these tracks. Second, a more gradual development, such as the one of the late 20th century convergence movement, happened during a time of relative political tranquility. During this period, policymakers were able to focus on corporate governance issues, rather than larger political or distributive concerns, and focused on perceived inefficiencies. After all, this is the period when the concern of agency cost came into the core focus of the debate.

COVID-19 came into the corporate governance world as a shock at the far tail end of the convergence. However, as general economic measures of international trade indicate

Council of 17 May 2017, Amending Directive 2007/36/EC as Regards the Encouragement of Long-term Shareholder Engagement, art. 9a, 2017 O.J. (L 132) 1. See generally Randall S. Thomas \& Christoph Van der Elst, Say on Pay Around the World, 92 WASH. U. L. REV. 653 (2015) (examining the wave of "say on pay" laws enacted in various countries since 2002); Luca Enriques et al., Related Party Transactions, in ANATOMY OF CORPORATE LAW, supra note 100, at 145, 157; Li-Wen Lin, Who Decides Executive Pay? A Comparative Perspective, in RESEARCH HANDBOOK ON COMPARATIVE CORPORATE GOVERnANCE (Afra Afsharipour \& Martin Gelter eds., forthcoming 2021).

134. See Jennifer G. Hill, Good Activist/Bad Activist: The Rise of International Stewardship Codes, 41 SEATTLE U. L. REV. 497, 503-06 (2018) (situating the shareholder stewardship codes adopted by the United Kingdom and other nations following the 2008-09 financial crisis inside a "positive narrative" of shareholder power); Dionysia Katelouzou \& Mathias Siems, The Global Diffusion of Stewardship Codes (ECGI Working Paper Series L., Working Paper No. 526/2020, 2020), https://ssrn.com/abstract=3616798 (discussing the UK Stewardship Code of 2020 and its goals in the United Kingdom).

135. For France, see Marco Becht et al., Loyalty Shares with Tenure Voting -Does the Default Rule Matter? Evidence from the Loi Florange Experiment (ECGI Working Paper Series L., Working Paper No. 398/2018, 2020), https://ssrn.com/abstract=3166494; Mariana Pargendler, The Grip of Nationalism on Corporate Law, 95 IND. L.J. 533, 543-44 (2020) (both discussing the French "Florange" law, which made loyalty shares with multiple voting rights for long-term shareholders the default); for Italy, see di Augusto Santoro et al., Deviations from the "One Share-One Vote" Principle in Italy: Recent Developments-Multiple Voting Rights Shares and Loyalty Shares, 5 BOCCONI L. PAPERS 141 (2015) (reviewing the repudiation of Italy's “one share- one vote" principle); Alessio M. Pacces, Exit, Voice and Loyalty from the Perspective of Hedge Funds Activism in Corporate Governance, 9 ERASMus L. REV. 199, 213 (2016); Chiara Mosca, Should Shareholders Be Rewarded for Loyalty? European Experiments on the Wedge Between Tenured Voting and Takeover Law, 8 MicH. BuS. \& ENTREPRENEURIAL L. REV. 245, 252-54 (2019).

136. Infra notes $341-343$ and accompanying text. 
that the world has moved from "globalization" to "slowbalization,"137 corporate governance has shifted from convergence to a mixed picture after 2008. While in some areas, we have seen continued convergence toward a shareholder model, in others we are experiencing a variety of developments across countries no longer in line with an ascendancy of proshareholder structures. Thus, corporate governance seems to be converging and diverging concurrently, in a phenomenon one could describe as "slowvergence."

\section{THREE KEY COVID-19 TRENDS}

We now turn to corporate governance effects of the economic crisis triggered by COVID-19. We argue that corporations will be subject to principally three types of pressures that will affect corporate governance, also in the long run. First, we discuss the move from "efficient" toward resilient corporate governance structures, considering both financial and labor aspects (Section IV.A), which, in spite of some debate, is a reverse of a precursory trend. We then discuss the return of nationalism (or protectionism) to corporate governance, which had previously persisted only in vestigial form (Section IV.B). We finally describe the resurgence of stakeholder models in corporate governance, which continues the trend of the past years (Section IV.C).

\section{A. The Turn from "Efficient" to Resilient Structures}

\section{Corporate Fat and the Agency Cost of Free Cash Flow}

In production logistics and sales, firms have been moving toward a certain type of efficiency in recent decades. First, firms have created regional and sometimes global supply chains. ${ }^{138}$ Elements of the value chain are produced where they are cheapest, thus allowing firms to benefit from economies of scale, ${ }^{139}$ individual countries' comparative advantages and lower labor costs, ${ }^{140}$ as well as strategically placing production close to

137. Supra notes $35-36$ and accompanying text.

138. Richard Baldwin, Global Supply Chains: Why They Emerged, Why They Matter, and Where They Are Going, in Global Value Chains in A Changing World 13, 17-20 (Deborah K. Elms \& Patrick Low eds., 2013); Baldwin \& Lopez-Gonzalez, supra note 9, at 1691, 1695 (noting the regional nature of supply chains); Prema-chandra Athukorala et al., Global Supply Chains: Towards a Computable General Equilibrium Analysis, 37 ECON. PAPERS 198, 198 (2018).

139. E.g., Zdenko Segetlija \& Davor Dujak, Retail Supply Chains and Efficiency of Retail Trade, 10 LOGFORUM 319, 321 (2014) (noting that retail supply chains allow firms to concentrate certain functions in certain countries).

140. John Zysman \& Andrew Schwartz, Reunifying Europe in an Emerging World Economy: Economic Heterogeneity, New Industrial Options, and Political Choices, 36 J. COMMON MKT. STUD. 405, 418 (1998); Baldwin, supra note 138, at 30, 31, 36; Baldwin \& Lopez-Gonzalez, supra note 9, at 1684-85 (discussing comparative advantage); Lennert C. Kaplan et al., Supply-Chain Trade and Labor Market Outcomes: The Case of the 2004 European Union Enlargement, 26 REV. INT'L ECON. 495 (2018) (noting a difference between Western and Eastern 
natural resources. ${ }^{141}$ Second, firms have emphasized "just-in-time" logistics. This means that interim products are delivered to the production process only shortly before they are needed. This has the advantage that the capital is not tied up in inventory, thus making the production process leaner and reducing the firm's financing needs. ${ }^{142}$ It does require dependable transportation systems and reliable suppliers to achieve its intended effects; ${ }^{143}$ in other words, firms must operate in a low-risk environment. ${ }^{144}$ This is particularly true in integrated markets, such as the European Union, where there are normally only random border inspections within the Schengen zone, and no customs controls within the union. Consequently, firms have come to rely on cross-border deliveries to a larger extent. ${ }^{145}$ During the COVID-19 pandemic, firms were increasingly forced to rely on larger inventory stocks ("just-in-case" logistics) and slower transportation methods (e.g., ocean carriage instead of cargo flights) because of interrupted or clogged supply chains causing bottlenecks. Thus, firms have begun to bring supply chains closer to their home operations in anticipation of future lockdowns ${ }^{146}$ and other disruptions. ${ }^{147}$

A parallel phenomenon has emerged in capital markets. Here, "efficiency" entails that capital can flow to its highest value use ${ }^{148}$ with little transaction costs. This is of course

European countries in terms of the level of skill in the labor provided within supply chains).

141. Zysman \& Schwartz, supra note 140, at 410; Henry Birdseye Weil, The Dynamics of Global Supply Chains: The Imperatives for Success in the New Market Ecology, in Global Value Chains IN A Changing WORLD 171-72 (D. Elms \& P. Low eds., 2013).

142. E.g., Cornelia Dröge \& Richard Germain, The Just-in-Time Inventory Effect: Does It Hold Under Different Contextual, Environmental, and Organizational Conditions, 19 J. Bus. LoGISTICs 53, 55-56, 64-65 (1998) (explaining the inventory effect of just-in-time logistics); Chan et al., supra note 9, at 6295-96.

143. James H. Perry, Firm Behavior and Operating Performance in Just-in-Time Logistics Channels, $9 \mathrm{~J}$. BuS. LogistiCs 19, 21 (1988); M.S. Spencer et al., Logistics Support for JIT Implementation, 34 INT'L J. PROD. RSCH. 701, 705 (1996); Gary Carleton, Wringing Cost out of the Supply Chain, 24 WoRLD TRADE 34, 35-36.

144. See Bernard Wysocki Jr. \& Sarah Lueck, Just-in-Time Inventories Make U.S. Vulnerable in a Pandemic, WaLl ST. J. (Jan. 12, 2006, 12:01 AM), https://www.wsj.com/articles/SB113703203939544469 [https://perma.cc/4AWW-U5E8] (stating hospitals often carry a limited supply of drugs because to do otherwise would be too costly).

145. E.g., Supply Chain: The Great European Expansion, 14 TradE Fin. 94 (2011); Baldwin \& LopezGonzalez, supra note 9, at 1710-11 (discussing "factory Europe"); Bruno Merlevede \& Victoria Purice, Border Regimes and Knowledge Spillovers Through the Supply Chain, VOXEU (Mar. 29, 2019), https://voxeu.org/article/border-regimes-and-knowledge-spillovers-through-supply-chain [https://perma.cc/2NDS-6U45] (discussing economic integration as a result of EU membership, which is enhanced by membership in the Schengen agreement); see also Kaplan et al., supra note 140, at 481 (finding that the 2004 EU enlargement has served to integrate new member states into Western European supply chains).

146. Julie Steinberg \& Joe Wallace, As Inventories Swell, Companies Turn to Novel Strategies to Get Through Coronavirus Crisis, WALL ST. J. (Aug. 8, 2020, 8:00 AM), https://www.wsj.com/articles/as-inventoriesswell-companies-turn-to-novel-strategies-to-get-through-coronavirus-crisis-11596888000 [https://perma.cc/NGB7-VFD4].

147. Mike Cherney, Firms Want to Adjust Supply Chains Post-Pandemic, but Changes Take Time, WALL ST. J. (Dec. 27, 2020, 10:00 AM), https://www.wsj.com/articles/firms-want-to-adjust-supply-chains-post-pandemic-but-changes-take-time-11609081200 [https://perma.cc/D7LF-EUVK]; see also Willy C. Shih, Global Supply Chains in a Post-Pandemic World, HARV. Bus. REv. 83, 86 (2020) (suggesting that manufacturers should follow a regional and diversified strategy to protect their supply chains).

148. Eugene F. Fama, Efficient Capital Markets: A Review of Theory and Empirical Work, 25 J. Fin. 383, 383 (1970) (noting that "the ideal is a market in which prices provide accurate signals for resource allocation"); Raghuram G. Rajan \& Luigi Zingales, Which Capitalism? Lessons from the East Asian Crisis, 11 J. APPLIED CORP. FIn. 40, 40-41 (1998); Kevin Haeberle, Stock-Market Law and the Accuracy of Public Companies' Stock 
possible only when investors can disinvest from one company and invest in another company, as well as diversify their holdings. ${ }^{149}$ Unlike investors in a mutual fund, shareholders in a corporation cannot normally decide to sell back stock to the corporation at will. They may only sell them in the market, in which case a low-value use will result in downward pressure on the stock price, which is generally disfavored by management. ${ }^{150}$ Firms can forestall downward price pressure by returning capital to shareholders at their own volition, either through dividends or share repurchases. ${ }^{151}$ Sometimes they are essentially forced to return underused capital to stockholders in a hostile takeover. ${ }^{152}$

Excess resources that remain in the firm and are not put to good use are thus often seen as detrimental and a potential source of agency cost. Managers are usually thought to have an incentive to retain excessive funds in the firm because it insulates them from market discipline. ${ }^{153}$ Managers are more likely to take action increasing their own welfare (at the expense of shareholders) if they have discretion over cash. ${ }^{154}$ These "agency costs of free cash flow" can be countered with debt; if there is a constant interest burden to meet, managers have fewer options to squander unused funds. ${ }^{155}$ In light of this, repurchases of shares are often thought to be beneficial because they return unused cash to shareholders. ${ }^{156}$ In the United States, arguably, the free cash flow problem largely disappeared during the 1980 s with increased reliance on corporate debt. ${ }^{157}$

In recent years, share repurchases have become more common, ${ }^{158}$ and an increasing

Prices, 2015 Colum. Bus. L. Rev. 122, 137-39 (2015).

149. John Armour et al., What Is Corporate Law, in The ANATOMY OF CORPORATE LAW, supra note 100, at 1,10 .

150. Zohar Goshen \& Gideon Parchomovsky, The Essential Role of Securities Regulation, 55 DUKE L.J. 711, 726 (2006); Haeberle, supra note 148, at 132.

151. See Michael Bradley \& Michael Rosenzweig, Defensive Stock Repurchases, 99 Harv. L. Rev. 1377, 1378 (1986) (discussing repurchases intended to raise stock price to inhibit hostile takeovers); Wm. Gerard Sanders \& Mason A. Carpenter, Strategic Satisficing? A Behavioral-Agency Theory Perspective on Stock Repurchase Program Announcements, 46 ACAD. MGMT. J. 160, 161 (2003) ("Repurchase programs tend to result in persistently higher stock prices and, eventually, increased earnings per share.”) (citation omitted); Ken C. Yook \& Partha Gangopadhyay, Free Cash Flow and the Wealth Effects of Stock Repurchase Announcements, 49 Q.J. Fin. \& Асст. 23, 23 (2010) ("There is ample evidence . . that stock repurchases generate significantly positive announcement-period abnormal returns.").

152. Michael C. Jensen, Agency Costs of Free Cash Flow, Corporate Finance, and Takeovers, 76 AM. ECON. REV. 323, 328 (1986).

153. Michael S. Knoll, Taxing Prometheus: How the Corporate Interest Deduction Discourages Innovation and Risk-Taking, 38 VILL. L. REV. 1461, 1484 n.91 (1993); Mira Ganor, Agency Cost in the Era of Economic Crisis: The Enhanced Connection Between CEO Compensation and Corporate Cash Holdings, 55 ARIZ. L. REV. 105, 107-08 (2011); Rock, supra note 109, at 1914.

154. Jensen, supra note 152, at 324; see also Frank H. Easterbrook, Two Agency-Cost Explanations of Dividends, 74 AM. ECON. REv. 650, 654 (1984) ("Managers of firms with fixed capital structures may well have substantial discretion to be slothful, consume perquisites, or otherwise behave in their own interests rather than the investors' interests."); George G. Triantis, A Free-Cash-Flow Theory of Secured Debt and Creditor Priorities, 80 VA. L. REV. 2155, 2159 (1994) (stating managers are more likely to make self-interested decisions when they have more cash at their disposal).

155. Jensen, supra note 152 , at 324 .

156. Yook \& Gangopadhyay, supra note 151 , at 24, 26.

157. Rock, supra note 109, at 1919 (referring to data reported by Holmstrom \& Kaplan, supra note 108, at 124-25).

158. E.g., Alberto Manconi et al., Are Buybacks Good for Long-Term Shareholder Value? Evidence from 
subject of debate. ${ }^{159}$ The most simple explanation for buybacks is that it is efficient for firms with few investment opportunities that they should return capital to shareholders (who can invest it elsewhere more productively). ${ }^{160}$ Apart from that, managers often prefer repurchases to dividends because they reduce the number of outstanding shares, increase earnings per share, and signal to the market that their stock is undervalued. ${ }^{161}$ Finally, the signaling theory of share buybacks posits that well-run firms are better able to operate with smaller amounts of cash. Repurchases are therefore more costly for badly run firms, which is why a buyback allows well-run firms to signal their quality to investors. ${ }^{162}$

Share repurchases have become the subject of criticism from various sources in recent years. Critics argue that firms could use funds for more desirable purposes, such as capital expenditures, to pay workers better, or to better develop the business. ${ }^{163}$ Others are concerned that firms are becoming short-termist and sacrifice long-term investment for quick returns for shareholders. ${ }^{164}$ In this view, increased earnings per share after a repurchase are only window-dressing and do not represent long-term value creation. ${ }^{165}$ Managers may

Buybacks Around the World, 54 J. Fin. \& Quantitative Analysis 1899, 1899 (2019); Kathleen Kahle \& René M. Stulz, Why Are Corporate Payouts So High in the 2000s? (Dice Center, Working Paper No. 2020-20, 2020), http://ssrn.com/abstract=3678973 [https://perma.cc/5ZNS-BRJ4]. But see Jesse M. Fried \& Charles C.Y. Wang, Short-Termism and Capital Flows, 8 Rev. CoRP. Fin. STUD. 207 (2019), and Jesse M. Fried \& Charles C.Y. Wang, Short-Termism, Shareholder Payouts, and Investment in the EU (ECGI L. Working Paper No. 544/2020, 2021), http://ssrn.com/abstract=3706499 [https://perma.cc/55SP-EFDJ] (both suggesting that claims about the effects of buybacks are exaggerated in the United States and the EU because of concurrent equity issues).

159. Share repurchases have been discussed in Congress. House Financial Services Committee Sets Hearing on Stock Buybacks, THOMSON REUTERS TAX \& ACCT., 2019 WL 8330145 (Oct. 7, 2019).

160. E.g., Jesse M. Fried, Insider Signaling and Insider Trading with Repurchase Tender Offers, 67 U. CHI. L. REV. 421, 438-39 (2000) (giving the example of returning cash to investors so they can invest it outside the corporation); Amy Dittmar, Why Do Firms Repurchase Stock?, 73 J. Bus. 331, 333-34 (2000); Mitchell Miller \& Dale Prondzinski, Stock Repurchases: Do They Add to Shareholder Value over Time?, 17 J. ACCT. \& FIN. 48, 49 (2017) (stating that stock buybacks dispose of excess cash for the efficiency of the business).

161. Stanley Block, Should Banks Repurchase Their Own Shares?, 24 BANK ACCT. \& Fin. 29, 29, 31 (2010) (reporting surveys among bank managers showing the signaling effect as a major motivation for repurchases); Miller \& Prondzinski, supra note 160, at 50; Bruce Dravis, Dilution, Disclosure, Equity Compensation, and Buybacks, 74 Bus. LAW. 631, 632 (2019) (discussing earnings per share).

162. E.g., Fried, supra note 160, at $441-45$ (explaining how signaling theory makes it possible to credibly announce the stock price is too low); Jacob Oded, Why Do Firms Announce Open-Market Repurchase Programs?, 18 REV. FIN. STUD. 271, 274 (2005) (providing a hypothetical signaling model); Matthew T. Billett \& Miaomiao Yu, Asymmetric Information, Financial Reporting, and Open-Market Share Repurchases, 51 J. FIN. \& QuANTITATIVE ANALYSIS 1165, 1167 (2016) ("Myriad theoretical studies show that payout policy can signal insider information to outside investors and mitigates the effects of asymmetric information"); Alana M. Mackey \& Frank W. Bacon, Signaling with Stock Issues and Repurchases: A Test of Semi-Strong Form Market Efficiency, 29 J. BUS. \& BEHAV. SCI. 34, 35-36 (2017) (explaining how companies will engage in equity issuance or stock repurchases to signal their stock price is overrated or undervalued). But see Fried, supra note 160, at 445, and Manuel A. Utset, Fraudulent Corporate Signals: Conduct as Securities Fraud, 54 B.C. L. REv. 645, 660 (2013) (both criticizing signaling theory).

163. Dravis, supra note 161 , at 650-51 (providing details about the sources of criticism).

164. William Lazonick, Profits Without Prosperity, HARV. Bus. ReV., Sept. 2014, at 46, 48-49; Disclosure Rules for Stock Buybacks to Get a Review, THOMSON REUTERS TAX \& ACCT., 2016 WL 11676028 (Feb. 4, 2016).

165. Sanders \& Carpenter, supra note 151, at 161; but see Manconi et al., supra note 158, at 1900 (noting that this view is at odds with the empirical literature in the United States, which tends to find increased long-term value of firms after repurchases); see also id. at 1930 (suggesting, based on empirical analysis, that non-U.S. firms tend to repurchase shares for less benign reasons, such as defending against takeovers, avoiding the dilution 
gain from them because of the way in which executive compensation plans reward increases in stock price. ${ }^{166}$ In addition, politicians have criticized repurchases for their purported redistributive effects from workers to shareholders. ${ }^{167}$

COVID-19 as an external shock to the corporate governance system led to a $30 \%$ reduction in buybacks in 2020. ${ }^{168}$ Over the medium and long term, firms may hold large amounts of cash to protect themselves against cash flow shocks. ${ }^{169}$ Efficiency-oriented structures that do well in calm waters may not be best suited to survive a storm that hits the economy as a whole. For example, Warren Buffett suggested that the conglomerate he controls, Berkshire Hathaway, is well-positioned in the present situation because it holds significant amounts of cash reserves. ${ }^{170}$ In uncertain times, significant reserves may thus make a firm more resilient to shocks. Referring to a phrase coined by Chicago economist Luigi Zingales, Oxford law professor John Armour has called this phenomenon "survival of the fattest." 171 In his study of the trucking industry, Zingales found that when an exogenous shock happened - namely deregulation - firms started to compete on price, which resulted in the elimination chiefly of the more highly leveraged firms from the market. ${ }^{172}$

Understandably, the aversion to payouts to shareholders is influencing policies relating to government bailouts. For example, the U.S. CARES Act requires that federal loans and guarantees may only be made to firms that commit not to repurchase equity or pay

of earnings per share, and saving personal taxes).

166. Dittmar, supra note 160, at 335; Sanders \& Carpenter, supra note 151, at 165; David Bendig et al., Share Repurchases and Myopia: Implications on the Stock and Consumer Markets, 82 J. MKTG. 19, $24-25$ (2018); Nitzan Shilon, Pay for Destruction: The Stock Buybacks That Make CEOs Rich but Impoverish Their Firms (2021), https://ssrn.com/abstract=3678734 [https://perma.cc/AX5W-BH44]; Fei Leng \& Kevin Min Zhao, Insider Trading Around Open-Market Share Repurchases, 38 J. ECON. FIN. 461 (2014) (discussing insider trading behavior around repurchases); see generally Jesse M. Fried, Informed Trading and False Signaling with Open Market Repurchases, 93 CALIF. L. REV. 1323 (2005) (suggesting that managers may use repurchases to drive up the stock price before selling stock).

167. Chuck Schumer \& Bernie Sanders, Schumer and Sanders: Limit Corporate Stock Buybacks, N.Y. TiMES (Feb. 3, 2019), https://www.nytimes.com/2019/02/03/opinion/chuck-schumer-bernie-sanders.html [https://perma.cc/B8HP-9TFG].

168. Randall Smith, Stock Buybacks: What Every Investor Needs to Know, WALL ST. J. (Dec. 5, 2020, 11:31 AM), https://www.wsj.com/articles/stock-buybacks-what-every-investor-needs-to-know-11607185864 [https://perma.cc/8RXZ-SLZC].

169. Thomas W. Bates et al., Why Do U.S. Firms Hold Much More Cash Than They Used To?, 64 J. Fin. 1985, 1988-89 (2009).

170. Theron Mohamed, Warren Buffett's Berkshire Hathaway Has a Record \$137 Billion Investor Cash Pile. Here's Why the Investor Will Be Frustrated by That Fact, BUS. INSIDER (May 8, 2020, 6:33 AM), https://markets.businessinsider.com/news/stocks/why-warren-buffett-unhappy-berkshire-hathaway-record-137billion-cash-2020-4-1029181516 [https://perma.cc/Y5QH-Q5LX].

171. John Armour et al., The COVID-19 Crisis and Its Aftermath: University of Oxford and Imperial College London Session, ECGI (Apr. 30, 2020), https://ecgi.global/video/covid-19-crisis-and-its-aftermath-university-oxford-and-imperial-college-london-session [https://perma.cc/35JH-39FJ].

172. Luigi Zingales, Survival of the Fittest or the Fattest? Exit and Financing in the Trucking Industry, 53 J. FIN. 905, 906 (1998). 
dividends within the next twelve months. ${ }^{173}$ Similar restrictions apply in European countries. ${ }^{174}$ Generally, share repurchases are facing increased scrutiny by the public, especially when the government steps up to help the economy during the pandemic. ${ }^{175}$ In addition, some have suggested that firms that have used tax loopholes should not be eligible for bailouts. ${ }^{176}$

In the comparative dimension, there appear to be chiefly two explanations of international differences in cash holdings. First, some studies suggest that firms in countries where investors are less well-protected against managerial agency costs tend to hold more cash. ${ }^{177}$ Second, other studies suggest that firms in countries with certain cultural traits, especially "uncertainty avoidance" on the well-known Hofstede scale, ${ }^{178}$ have larger cash holdings relative to their size. ${ }^{179}$ However, some of the international differences are likely driven by the variance in the composition of the population of publicly traded companies. ${ }^{180}$ The

173. Coronavirus Aid, Relief, and Economic Security Act (CARES) Act of 2020, Pub. L. No. 116-136, § 4003(c)(2)(E), (F), (3)(i)(I)-(II), 134 Stat. 281, 471-72. For a more radical position, see, for example, Matt Stoller, Five Conditions for Corporations About to Receive Coronavirus Bailouts, PROMARKET (Mar. 17, 2020), https://promarket.org/2020/03/17/five-conditions-for-corporations-about-to-receive-coronavirus-bailouts/ [https://perma.cc/8HPN-JKUS] (suggesting that firms should no longer be allowed to make buybacks and not pay any dividends for five years).

174. Angelo Borselli \& Ignacio Farrando Miguel, Corporate Law Rules in Emergency Times Across Europe, 17 EUR. Co. \& Fin. L. REv. 274, 308-09 (surveying the United Kingdom, France, Germany, Italy, and Spain). In addition, bank regulators around the world introduced limits on dividends and buybacks during the pandemic. See Patricia Kowsmann, European Bank Dividend Ban Lifted, but Restrictions Remain, WALL ST. J. (Dec. 15, 2020, 2:36 PM), https://www.wsj.com/articles/european-bank-dividend-ban-lifted-but-restrictions-remain11608060995 [https://perma.cc/Y8V2-S26L] (covering the limitations).

175. E.g., Oliver Schutzmann, Covid-19 Prompts Buyback Backlash, IR MAG. (Apr. 14, 2020), https://www.irmagazine.com/covid-19/covid-19-prompts-buyback-backlash [https://perma.cc/TEH6-35ZF]; Sabrina Kessler, Coronavirus Stops Share Buybacks That Fueled Equities Rally, DeUTSCHE Welle (May 6, 2020), https://www.dw.com/en/coronavirus-stops-share-buybacks-that-fueled-equities-rally/a-53351391

[https://perma.cc/MHU7-UTS9]; Lynn S. Paine, Covid-19 Is Rewriting the Rules of Corporate Governance, HARV. BUS. REV. (Oct. 6, 2020), https://hbr.org/2020/10/covid-19-is-rewriting-the-rules-of-corporate-governance [https://perma.cc/K8LD-FU59].

176. See Neeti Biyani \& Alvic Padilla, 'COVID-19 Bailouts': The Great Corporate Rescue at Any Price?, FIN. TRANSPARENCY COAL. (May 25, 2020), https://financialtransparency.org/covid-19-bailouts-great-corporaterescue-price/ [https://perma.cc/UR3N-H2T2] (covering an example).

177. Amy Dittmar et al., International Corporate Governance and Corporate Cash Holdings, 38 J. FIN. \& Quantitative Analysis 111 passim (2003); Lee Pinkowitz et al., Does the Contribution of Corporate Cash Holdings and Dividends to Firm Value Depend on Governance? A Cross-Country Analysis, 61 J. FIN. 2725 (2006); Ivalina Kalcheva \& Karl V. Lins, International Evidence on Cash Holdings and Expected Managerial Agency Problems, 20 ReV. Fin. STUD. 1087 (2007).

178. See generally GeERT Hofstede, Culture's Consequences: InTERnational DifFerences in WORK-RELATED VALUES (1980) (comparing national cultures along the dimensions of power distance, individualism, masculinity, uncertainty avoidance, and long-term orientation).

179. See generally Andrés Ramírez \& Solomon Tadesse, Corporate Cash Holdings, Uncertainty Avoidance, and the Multinationality of Firms, 18 INT'L BuS. REV. 387 (2009); Yangyang Chen et al., National Culture and Corporate Cash Holdings Around the World, 50 J. BANKING \& FIN. 1 (2015) (finding that individualism is negatively associated with cash holdings, while uncertainty avoidance is positively associated).

180. See Lee Pinkowitz et al., Do U.S. Firms Hold More Cash Than Foreign Firms Do?, 29 Rev. Fin. STud. 309 (2016) (finding that U.S. firms hold more cash than firms elsewhere, which is explained by firm-level differences but not country-level differences); see also John R. Graham \& Mark T. Leary, The Evolution of Corporate Cash, 31 REv. FIN. STUD. 4288 (2018) (showing that some of the changes within the United States over time are 
trend toward larger cash holdings in the United States during the early 2000s, for example, was driven by tech firms trading on NASDAQ. ${ }^{181}$

A phenomenon paralleling cash holdings is "empire-building" by management, which is often thought to be another source of agency cost, especially when firms merge to form conglomerates. ${ }^{182}$ The main problem here is that shareholders can better diversify their capital by spreading it across firms; from there, it is not necessarily an advantage in a specific firm being diversified. ${ }^{183}$ Moreover, managers have more opportunities to engage in wasteful activities across multiple divisions. ${ }^{184}$ Thus, such firms often trade at a "diversification discount." 185

On the positive side, large conglomerates (or firms) may not necessarily be better positioned to survive a crisis in comparison to smaller ones. However, firms that are better internally diversified may be better equipped because they are active in a larger number of lines of businesses. ${ }^{186}$ If a firm's cashflows are consequently less variable, the more profitable divisions may be able to cross-subsidize the harder-hit ones, thus enabling the whole firm to survive. ${ }^{187}$ Thus, while the creation of conglomerates is often thought to be an example of an agency cost, ${ }^{188}$ firms with more diversified cashflow streams may be better positioned to survive a severe crisis with some bruises. Conglomerates are no longer common in the United States, in part because of takeovers in the 1980s and 1990s, ${ }^{189}$ but they persist in other parts of the world, such as East Asia. ${ }^{190}$

Overall, it may well be that firms carrying more "fat"-either in the form of cash holdings or internal diversification - are better positioned to survive the initial COVID-19 shock. Similar to Zingales' findings in the U.S. trucking industry after deregulation, ${ }^{191}$ the "fatter" firms might persist. It is much more difficult to make predictions across countries. First, the initial population of firms will differ. If a law is not effective in protecting shareholders against agency cost and a cultural trait of uncertainty avoidance are indeed drivers of cash hoarding, ${ }^{192}$ then these factors will already have shaped the existing population of

driven by differences in the population of companies).

181. Graham \& Leary, supra note 180.

182. See Jensen, supra note 152, at 327 (discussing company purchases outside of the industry by oil companies).

183. Rock, supra note 109, at 1915.

184. See, e.g., Raghuram Rajan et al., The Cost of Diversity: The Diversification Discount and Inefficient Investment, 55 J. FIN. 35, 36 (2000) ("[M]odel[ing] the distortion that internal power struggles can generate in the allocation of resources between divisions of a diversified form").

185. Id. at $49-50$ (modeling reasons for this discount).

186. Rock, supra note 109, at 1915.

187. See Rajan et al., supra note 184, at 39; Martin F. Hellwig et al., Conglomeration: Good, Bad, or Unavoidable?, 54 SCHMALENBACH Bus. REV. 55, 58 (2002) (discussing cross-subsidization between divisions of a conglomerate); see also Rajan \& Zingales, supra note 148, at 44-45 (discussing specific examples).

188. Yakov Amihud \& Baruch Lev, Risk Reduction as a Managerial Motive for Conglomerate Mergers, 12 BELL J. ECON. 605 (1981) (suggesting that conglomerate mergers allowed managers to diversify their employment risk); but see Andrei Shleifer \& Robert W. Vishny, The Takeover Wave of the 1980s, 249 SCI. 745, 746 (1990) (speculating that conglomerates can allocate funds efficiently by creating internal capital markets).

189. Rock, supra note 109, at 1921.

190. E.g., Kon Sik Kim, Related Party Transactions in Asia, in The LaW and FinanCe OF Related Party TRANSACTIONS 285, 287-89 (Luca Enriques \& Tobias Tröger eds., 2019).

191. Supra notes $169-172$ and accompanying text

192. Supra notes $177-181$ and accompanying text. 
firms, e.g., the industry in which a jurisdiction typically excels. In addition, idiosyncratic factors, including whether a country's government is likely to bail out firms in the private sector, will play a role.

A further factor influencing the short-run survival of firms is whether a country's bankruptcy system is effective at allowing firms to continue after reorganization, as with Chapter 11 in the United States, or whether insolvency is more likely to result in a breakup during liquidation of the firm. ${ }^{193}$ During the past two decades, many countries have attempted to gear their bankruptcy laws more strongly toward reorganization and firm survival with a new capital structure. ${ }^{194}$ To the extent an effective reorganization system is in place, firms as such will likely survive with new owners. ${ }^{195}$

The more interesting question is whether COVID-19 will not only be a one-time shock to the economy but create a generally less stable economic environment, for example, because of recurring lockdowns. This would not mean that a firm should accumulate as much fat as possible and hoard mountains of cash to survive or create conglomerates to mitigate the effects of potential shocks through diversification. However, the presence of recurring shocks may change the capital structure tradeoff when it comes to corporate fat. Under all circumstances, firms may have to balance the disadvantages of fat, such as increased agency costs, with its advantages, such as increased resiliency to crisis. For each firm, the optimal position on the tradeoff will also depend on other characteristics of the firm. For example, in a firm with large shareholders, managerial agency cost is usually not particularly significant.

Overall, it is still likely that the optimal point in the tradeoff will shift toward more corporate fat compared to the more stable pre-COVID environment across countries. One could speculate whether firms in some countries are more likely to be better positioned to survive shocks than others. It appears that the bankruptcy system will be less important for the long-run impact than for the initial shock. As economic shocks become more common, equity investors will —over time-increasingly insist on mechanisms being put into place that avoid shock-induced bankruptcy ex ante, which will likely include increased corporate fat. The survival of firms will depend largely on their adaptability. To the extent that countries do not inhibit cash hoarding through tax penalties, firms in most jurisdictions should be capable of adjustment. The creation of conglomerates and internal diversification may be more complex. Firms in jurisdictions that already have conglomerate structures will likely have a head start. We will return to this discussion in Section IV.C. 3 when we outline

193. See, e.g., John Armour et al., Corporate Ownership Structure and the Evolution of Bankruptcy Law: Lessons from the United Kingdom, 55 VAND. L. REV. 1699, 1723-30 (2002) (contrasting manager-driven and manager-displacing bankruptcy systems); Sefa Franken, Creditor- and Debtor-Oriented Corporate Bankruptcy Regimes Revisited, 5 EUR. BUS. ORG. L. REV. 645, 650-53 (2004) (comparing debtor- and creditor-oriented bankruptcy regimes); Horst Eidenmüller, Comparative Corporate Insolvency Law, in THE OXFORD HANDBOOK OF CORPORATE LAW AND GOVERNANCE, supra note 122, at 1003, 1006-08 (contrasting liquidation- and reorganization-oriented bankruptcy procedures).

194. See, e.g., Aurelio Gurrea-Martínez, The Future of Reorganization Procedures in the Era of Pre-Insolvency Law, 21 EUR. BUS. ORG. L. REV. 829, 833-35 (2020) (surveying reforms).

195. Many countries have amended their bankruptcy laws to let distressed companies avoid involuntary liquidation during COVID-19. For a survey, see OECD, NATIONAL CORPORATE Governance Related INITIATIVES DURING THE COVID-19 CRISIS, 25-35 (2020), http://www.oecd.org/corporate/National-corporategovernance-related-initiatives-during-the-covid-19-crisis.pdf [https://perma.cc/M5BA-VPCF]. 
macro-consequences for the evolution of corporate governance post-COVID-19.

\section{Relational Equity and Debt, and Corporate Embeddedness}

A related aspect of resilience could be described as a corporation's embeddedness into a larger economic network. A corporation can be referred to as more "embedded" if it is more strongly linked to other entities or individuals that are likely to provide aid in a crisis.

In large part, this relates to the question of ownership structure. We have already discussed differences in ownership structures across countries. Traditionally, U.S. and U.K. corporate governance have been characterized by dispersed ownership, where shareholders are diversified and typically hold only a small percentage of shares, thus allowing management independently. ${ }^{196}$ Most other jurisdictions, including wealthy industrialized countries in Europe and Asia, have long exhibited concentrated ownership, where controlling shareholders or coalitions of large shareholders exercise a significant influence on the firm. ${ }^{197}$ The views that have been most influential on corporate law scholarship typically consider concentrated ownership as an aberration (in spite of its prevalence), at least as far as agency costs are concerned. According to the "law matters" thesis, concentrated ownership persists because of bad corporate law that inadequately protects minority investors. ${ }^{198}$ Other views suggest a political influence that strengthens labor institutions; if these undermine effective monitoring by the board of directors, concentrated ownership persists in making up the gap. ${ }^{199}$

However, a different type of explanation sees corporate governance not only as focused on the agency costs between managers, inside shareholders, and outside shareholders, but rather as a set of institutional complementarities. Thus, concentrated ownership is not necessarily a dysfunctional consequence of bad law or politics but serves as a useful function in combination with other elements of the corporate governance system. In particular, scholars have long distinguished between countries characterized by an "arm's length" (or outsider) and a "control-oriented" (or insider) financial system. ${ }^{200}$ Arm's length

196. Supra notes 84-88 and accompanying text.

197. Supra notes 90-106 and accompanying text.

198. Rafael La Porta et al., Legal Determinants of External Finance, 52 J. Fin. 1131 (1997); Rafael La Porta et al., Law and Finance, 106 J. PoL. ECON. 1113, 1145-51 (1998); see also John C. Coffee, Jr., The Future as History: The Prospects for Global Convergence in Corporate Governance and Its Implications, 93 Nw. U. L. REV. 641, 647-48 (1999) (suggesting that federal securities laws are the protections needed for dispersed shareholders that supports the growth of the securities market); Bernard S. Black, The Legal and Institutional Preconditions for Strong Securities Markets, 48 UCLA L. REV. 781, 834-35 (2001); Brian R. Cheffins, Does Law Matter? The Separation of Ownership and Control in the United Kingdom, 30 J. LEGAL STUD. 459, 461-65 (2001). But see Albert H. Choi, Concentrated Ownership and Long-Term Shareholder Value, 8 HARV. BUS. L. REV. 53 (2018) (suggesting that private benefits of control up to a certain degree help to ensure necessary long-term commitment by large equity investors).

199. Mark J. Roe, Political Preconditions to Separating Ownership from Corporate Control, 53 STAN. L. REV. 539, 542 (2000); RoE, supra note 26, at 162; see also GOUREVITCH \& SHINN, supra note 90 (discussing corporate governance outcomes as a set of complex coalitions).

200. E.g., Berglöf, supra note 101, at 159-64 (differentiating between arms-length and control-oriented finance); DiGNAM \& GALANIS, supra note 4, at 64 (exploring the globalization of corporate governance); Leuz, supra note 101, at 236-37 (comparing two stylized approaches to reporting regulation); see also Reinhard $\mathrm{H}$. Schmidt \& Marcel Tyrell, Financial Systems, Corporate Finance and Corporate Governance, 3 EUR. FIN. MGMT. 333, 334 (1997) (contrasting market-based and bank-based financial systems); Gelter, supra note 92, at 176-81 
systems rely on anonymous relations - mediated mainly through public and stock and bond markets - to provide companies with finance, where providers of finance rely on legal rights and their enforcement. ${ }^{201}$ In control-oriented systems, the major providers of finance (such as banks or large shareholders) tend to intervene to secure their rights (which is possible because such investors hold larger stakes). ${ }^{202}$ Each system has advantages and disadvantages. While outside systems allow for relatively fast capital flows and reduce the firm's risk of being at the mercy of the opportunism of another party (e.g., private benefits of control taken by a controlling shareholder), inside systems require long-term relationships. ${ }^{203}$ Relational systems appear to have an advantage in environments with a great deal of uncertainty, for example, because of inadequate legal protections. ${ }^{204}$

Some scholars take this argument further and have suggested that different financial market and labor market institutions stand in a complementary relationship with each other. Empirically, labor and employment law strengthening the position of workers tends to prevail in jurisdictions with concentrated ownership. ${ }^{205}$ One body of scholarship, the so-called "varieties of capitalism" theory, classifies socio-economic systems in different countries into "liberal" capitalist systems (such as the United States and the United Kingdom) on the one hand, and "coordinated" capitalist systems on the other hand. While the former relies mainly on arm's length market transactions between individual actors to coordinate economic activity, the latter relies more often on aggregate interest groups, such as associations representing business interests and unions which would then engage in long-term collective agreements. ${ }^{206}$ Firms in coordinated systems tend to make use of internal labor markets and specific human capital commitment to a larger extent, which requires a longterm cooperative arrangement to avoid opportunism from either side. ${ }^{207}$ However, such a labor system requires a level of commitment by shareholders to ensure to employees that their specific investment is safe. ${ }^{208}$

(describing institutional complementarities between the strength of shareholder and labor power).

201. Schmidt \& Tyrell, supra note 200, at 343; Leuz, supra note 101, at 237.

202. Berglöf, supra note 101, at 159-64.

203. Rajan \& Zingales, supra note 148, at 40; Leuz, supra note 101, at 237; DigNAM \& GALANIS, supra note 4, at 68 (discussing bank-based corporate governance systems); see also FRANKLIN ALLEN \& DougLAS GALE, COMPARING FINANCIAL SYSTEMS 19-22 (2000) (analyzing advantages and disadvantages).

204. Rajan \& Zingales, supra note 148, at 41 ("Relationship-based systems can survive in environments where laws are poorly drafted or contracts not enforced.").

205. RoE, supra note 26, at 52; Belloc \& Pagano, supra note 94, at 107.

206. See generally Peter A. Hall \& David Soskice, An Introduction to Varieties of Capitalism, in VARIETIES of CAPITALisM: The Institutional Foundations of Comparative AdVANTAGE 1, 8-9 (Peter A. Hall \& David Soskice eds., 2001); Richard W. CARNEY, CONTESTED CAPITALISM 3 (2010) (both discussing the distinction between the two types of capitalism).

207. DignAM \& GALANIS, supra note 4, at 75-76.

208. It is not entirely clear whether and under which circumstances a dispersed or a concentrated ownership structure is more conducive to commitment. For a theoretical model, see Giulio Ecchia et al., Corporate Governance, Corporate and Employment Law, and the Costs of Expropriation, 8 REV. L. \& ECON. 457 (2012); see also Gelter, supra note 92, at 176-81; Belloc \& Pagano, supra note 94; Gelter, supra note 121, at 48-50; Mark J. Roe \& Massimiliano Vatiero, Corporate Governance and Its Political Economy, in OXFORD HANDBook OF CORPORATE LAW AND GOVERNANCE, supra note 122, at 56, 67-70; see also Ugo Pagano, The Evolution of the American Corporation and Global Organizational Biodiversity, 35 SEATTLE U. L. REV. 1271, 1279-90 (2012) (discussing historical origins). 
A major takeaway from these theoretical frameworks is that some firms are more embedded into a network of long-term relationships than others, and we see more of them in some countries than in others. Arguably, embeddedness can be an advantage in times of crisis. ${ }^{209}$ First, large shareholders typically find it hard to disinvest and cannot generate market pressures toward a low stock price by selling. Blocks can only be sold strategically. Moreover, as strategic investors, they have a non-diversified position that creates an incentive for them to ensure the survival of the corporation. This is true most of all when the government is a key shareholder of a firm, in which case it will typically pursue political goals with its ownership stake. But even in the case of family shareholders or key industrial or industry shareholders, firms may benefit from being integrated into a larger, long-term corporate network or group. Key shareholders, if they are firms less affected by a crisis, or if they are a government or family with a long-term interest in the survival of the firm, may be more inclined to bail out a corporation in crisis. In this vein, evidence from the initial COVID-19 shock in Italy suggests that family-controlled firms were more likely to survive. ${ }^{210}$ Family firms often provide better connections to lenders ${ }^{211}$ or politics. $^{212}$ In addition, family owners may have a long-term connection with their workforce or the community where they are located, which may create an additional motivation to continue the firm. ${ }^{213}$

Another structure that can provide resiliency are business networks with cross-ownership, such as a Japanese keiretsu. ${ }^{214}$ Much like in a conglomerate as described in the previous section, the group as a whole will typically be diversified and in part function as a unit, which may allow it to shield individual firms from harm if they are more affected by shock than others in the group. With the "main bank" playing a key role in Japanese cross-ownership structures, banks have been known to sometimes orchestrate the rescue of a struggling firm. ${ }^{215}$

209. See Tarun Khanna \& Krishna Palepu, Is Group Affiliation Profitable in Emerging Markets? An Analysis of Diversified Indian Business Groups, 55 J. FIN. 867 (2000) (showing that group affiliation is advantageous in an environment with weak economic institutions).

210. Mario Daniele Amore et al., Family Ownership During the Covid-19 Pandemic (May 20, 2020), (unpublished manuscript), available at https://ssrn.com/abstract=3603991 [https://perma.cc/8EWH-4PZA].

211. Marianne Bertrand \& Antoinette Schoar, The Role of Family in Family Firms, 20 J. ECON. PERSPS. 73, 77-78 (2006); see generally Leandro D'Aurizio et al., Family Firms, Soft Information and Bank Lending in a Financial Crisis, 33 J. CORP. FIN. 279 (2015); Marco Cucculelli et al., Relational Capital in Lending Relationships: Evidence from European Family Firms, 52 SMALL BUS. ECON. 277 (2019) (both discussing capital lending and family firms).

212. See generally Mario Daniele Amore \& Alessandro Minichilli, Local Political Uncertainty, Family Control, and Investment Behavior, 53 J. FIN. \& QUANTITATIVE ANALYSIS 1781 (2018) (further discussing family firms); Mariana Pargendler, Controlling Shareholders in the Twenty-First Century: Complicating Corporate Governance Beyond Agency Costs, 45 J. CORP. L. 953, 966 (2020).

213. Bertrand \& Schoar, supra note 211, at 75-76; Laurent Bach \& Nicolas Serrano-Velarde, CEO Identity and Labor Contracts: Evidence from CEO Transitions, 33 J. CORP. FIN. 227 (2015); Carl Magnus Bjuggren, Sensitivity to Shocks and Implicit Employment Protection in Family Firms, 119 J. ECON. BEHAV. \& ORG. 18 (2015) (finding that family firms offer implicit employment protection); William Mullins \& Antoinette Schoar, How Do CEOs See Their Roles? Management Philosophies and Styles in Family and Non-Family Firms, 119 J. FIN. ECON. 24 (2016).

214. Supra notes 102-106 and accompanying text.

215. See Rajan \& Zingales, supra note 148, at 42 (providing the example of Mazda's rescue orchestrated by a bank). 
In other jurisdictions, typically corporate groups take different forms, e.g., with pyramidal ownership structures ${ }^{216}$ or with industrial companies holding considerable stakes in other firms in related industries. Group integration is often thought not to be beneficial for outside investors because controlling shareholders may self-deal or otherwise capture private benefits of control. ${ }^{217}$ In this vein, the law and finance literature has often posited that minority shareholder protection will reduce ownership concentration because there are fewer rents to gain. ${ }^{218}$ However, group integration often means that firms have made relationship-specific investments. They will repeatedly deal with each other, which implies that products in different stages of the production cycle may match each other, or logistical structures are coordinated. ${ }^{219}$ Thus, in a number of countries, the law takes group structures into account and allows for a more lenient approach, e.g., in the treatment of self-dealing transactions. ${ }^{220}$ Consequently, firms within corporate groups are interested in other firms within the group with which they are coordinated to survive. Of course, being organized as a group (rather than as a unitary firm) allows risk to be cabined within individual firms that could be permitted to go out of business. However, to the extent that group integration with a struggling firm is advantageous for other group firms, they will be more interested in organizing a rescue.

Finally, a similar argument can be made for (partial) government ownership of firms. The government may provide companies with patient capital, which may allow them to better withstand crises. ${ }^{221}$ In addition, government connections may endow corporations with political clout that could make public aid in difficult situations more likely. ${ }^{222}$

216. E.g., Enriques \& Volpin, supra note 127, at 119-20 (describing prominent examples of pyramids).

217. For a critical perspective, see, e.g., María Gutiérrez \& Maribel Sáez Lacave, Strong Shareholders, Weak Outside Investors, 18 J. CORP. L. STUD. 277, 294-98 (2018).

218. Supra notes 169-172 and accompanying text.

219. E.g., Tobias H. Tröger, Corporate Groups. A German's European Perspective, in GERMAN AND NoRdic PERSPECTIVES ON COMPANY LAW 157, 192-93 (Holger Fleischer et al. eds., 2015); Kim, supra note 190, at 287-89.

220. For example, German corporate group law allows for firms to suffer disadvantages from group integration provided that these are compensated within a year. Aktiengesetz [AktG] [Stock Corporation Act] $\S 311$ et seq. See Tröger, supra note 219, at 162-64 (explaining rules applying to "de facto groups"); Alexander Scheuch, Konzernrecht: An Overview of the German Regulation of Corporate Groups and Resulting Liability Issues, 13 EUR. Co. L. 191 (2016); Tobias H. Tröger, Germany's Reluctance to Regulate Related Party Transactions, in THE LAW AND FinANCE OF RELATED-PARTY TRANSACTIONS 426, 444-46 (Luca Enriques \& Tobias H. Tröger eds., 2019). French courts, following the "Rozenblum doctrine," exempt self-dealing transactions within a group from judicial scrutiny under certain circumstances. Trib. Corr. Paris, May 16, 1974, 1975 DALloz 37, 1975 REVUE DES SOCIETES 657. See Pierre-Henri Conac, Director's Duties in Groups of Companies-Legalizing the Interest of the Group at the European Level, 10 EuR. Co. \& Fin. L. REv. 194, $200-01$ (2013) (describing the French approach to groups). For a broader European overview, see Klaus J. Hopt, Groups of Companies: A Comparative Study of the Economics, Law, and Regulation of Corporate Groups, in OXFORD HANDBOOK OF CORPORATE LAW AND GOVERNANCE, supra note 122, at 624-25.

221. Sergio G. Lazzarini \& Aldo Musacchio, State Ownership Reinvented? Explaining Performance Differences Between State-Owned and Private Firms, 26 CORP. GovernANCE: INT'L ReV. 255, 258 (2018).

222. See Christine Zhenwei Qiang \& Georgiana Pop, State-Owned Enterprises and COVID-19: Policy Principles, WORLD BANK (July 30, 2020), https://blogs.worldbank.org/psd/state-owned-enterprises-and-covid-19policy-principles [https://perma.cc/5TA4-DBED] (finding SOEs were often bailed out by the government during the COVID-19 crisis); Luca Enriques, Pandemic-Resistant Corporate Law: How to Help Companies Cope with Existential Threats and Extreme Uncertainty During the Covid-19 Crisis, 17 Eur. Co. \& FIN. L. ReV. 257, 271 
Overall, we can summarize these various phenomena as "embeddedness," which encompass not only corporate ownership structures, long-term lending relationships, and customer-supplier relationships, but also possibly constructive long-term relationships with other stakeholders such as employees. Rajan and Zingales describe relationship-based financial systems as creating a system with "intertemporal cross-subsidies." ${ }^{223}$ We can generalize this point to various types of embeddedness, where the different players provide insurance for each other. Because they enjoy the advantageous continued existence of other players, they will have an incentive to orchestrate rescues, provide funding, and exert political pressures that make a government bailout more likely. There is no legal obligation, but embeddedness is making survival more likely.

Thus, if embeddedness permits a firm to better survive systemic shocks in a COVID19 world with a great degree of uncertainty, we may expect different forms of embeddedness to become more prevalent. This may include concentrated ownership structures and corporate groups of various shades, but also long-term lending and labor relationships. As for corporate "fat," ownership concentration and group integration entail various costs and benefits. In stable times, ownership dispersion may be cost-minimizing for most publicly traded firms. Whatever the costs and benefits otherwise, resilience may tip the scale further in favor of ownership concentration. Embeddedness in general may serve as a defense mechanism in a more uncertain environment.

\section{Human Capital and the Value of a Healthy Labor Force}

\section{i. Building a Resilient Workforce}

While the two preceding subsections have addressed the financial or capital side of corporate governance, COVID-19 may also have an impact on labor and how corporate management interacts with its workforce. The interests of workers are often thought to be outside the purview of corporate law, given that employees are not formally residual claimants like shareholders, and their interests are taken into account either by private contract or employment law. ${ }^{224}$ However, employees are often in fact in a similar position as residual claimants, as they may have made firm-specific investment in their human capital ${ }^{225}$ and have therefore transfer costs when moving to another employer. ${ }^{226}$ Another possible

(2020) (discussing the political capital necessary to secure government protection in the context of a hostile acquisition).

223. Rajan \& Zingales, supra note 148 , at 42.

224. Contra Kent Greenfield, The Place of Workers in Corporate Law, 39 B.C. L. REv. 283, 305-11 (1998) (arguing that workers are residual claimants).

225. On firm-specific investment, see GARY BECKER, HUMAN CAPITAL: A THEORETICAL AND EMPIRICAL ANALYSIS, WITH SPECIAL REFERENCE TO EDUCATION 11-36 (1964); see also James Malcomson, Individual Employment Contracts, in 3 HANDBOOK OF LABOR ECONOMICs 2291, 2311-37 (Orley Aschenfelter \& David Card eds., 1991); David Neumark, Productivity, Compensation, and Retirement, in OXFORD HANDBOOK OF PENSIONS AND RetiREMENT InCOME 721, 722 (Gordon Clark, Alicia Munnell \& J. Michael Orszag eds., 2006); Fauver \& Fuerst, supra note 107, at 679; Greenfield, supra note 224, at 302-03.

226. For example, a move may be prohibitively costly or impossible because of locally invested social capital. E.g., AnNaLee SAXENian, Regional Advantage: Culture And Competition In Silicon Valley and ROUTE 12835 (1994) (quoting an engineer contrasting the difficulty of getting another job in the same industry in Texas on one hand and the ease in Silicon Valley on the other). On specific human capital, see also Oliver E. 
way in which employees are "tied" to a particular employer are (defined benefit) pension plans, which sometimes create incentives to stay with a particular employer until retirement. ${ }^{227}$ These factors are sometimes brought forward as reasons why employees should play a role in corporate governance. Economic models suggest that employees may be subject to "holdup," i.e., an opportunistic renegotiation of their contracts and work arrangements. If they are supported by protections making holdup less likely, they will therefore be less likely to allow themselves to be exposed to such a risk, e.g., by avoiding specific human capital investment. ${ }^{228}$ Employee representation on the board, including German codetermination, has thus sometimes been interpreted as an efficiency-enhancing corporate governance mechanism, with possible advantages in certain industries. ${ }^{229}$

COVID-19 is adding another angle to the human capital creation, namely the resilience of the workforce to the pandemic. ${ }^{230}$ Employers will want workers to avoid contagion, especially because it could lead to a "clustered" outbreak within the firm, which could shut down production for significant amounts of time and result in bad publicity. ${ }^{231}$

Besides physical adjustments to the workplace, regular testing regimes and vaccines, ${ }^{232}$ the key to healthy employees will likely be found in the makeup of the workforce and its conduct relating to health in prevention, hygiene, monitoring, and social conduct. Since the outbreak of the pandemic, the focus on prevention and general interest in a healthy lifestyle has increased rapidly in terms of quality and quantity. ${ }^{233}$ Self-monitoring of health status and prevention through a holistic lifestyle has quickly leveraged into novel competitive advantages in all affected economies. Those who are healthier have better prerequisites for delving through COVID-19 with relatively little impact. Prevention has be-

Williamson et al., Understanding the Employment Relation: The Analysis of Idiosyncratic Exchange, 6 BELL J. ECON. 250 (1975); for specific human capital as combinations of skills, see Edward P. Lazear, Firm-Specific Human Capital: A Skill-Weights Approach, 117 J. POL. ECON. 914, 915 (2009). See also Egon Franck et al., Specific Human Capital as a Source of Superior Team Performance, 63 SCHMALENBACH Bus. REv. 376, 377-81 (2011) (analyzing human capital in highly interactive teams); John C. Coffee, Shareholders Versus Managers: The Strain in the Corporate Web, 85 MICH. L. REV. 1, 74 (1986); Greenfield, supra note 224, at 302.

227. See generally Richard A. IpPOLIto, PEnsion Plans AND EMPloyee PerformanCe 10-29 (1997) (discussing pension plans that create an implicit long-term contract between employers and employees); Gelter, supra note 88 , at $922-23$.

228. E.g., Margaret M. Blair \& Lynn A. Stout, Specific Investment and Corporate Law, 7 EuR. Bus. ORG. L. Rev. 473, 494 (2006); Richard Brealey et Al., Principles of CoRporate FinanCe 949 (8th ed. 2006); Gelter, supra note 92 , at 140 .

229. See Eirik G. Furubotn, Codetermination and the Modern Theory of the Firm: A Property-Rights Analysis, 61 J. BUS. 165, 170-74 (1988) (describing the voluntary variant of the codetermined firm); Fauver \& Fuerst, supra note 107; Gelter, supra note 92, at 169; Paul Davies, Efficiency Arguments for the Collective Representation of Workers: A Sketch, in THE AUTONOMY OF LABOUR LAW 367 (Alan Bogg et al., eds., 2015). But see Jens Dammann \& Horst Eidenmüller, Codetermination: A Poor Fit for US Corporations 24 (ECGI Law, Working Paper No. 509/2020, 2020), https://ssrn.com/abstract=3565955 [https://perma.cc/HXD9-96AS] (noting the lack of direct evidence that codetermination encourages firm-specific investment).

230. Salzburg Declaration, supra note 13.

231. See infra Section II.A (discussing working conditions during COVID-19).

232. On the legality of mandatory vaccine policies, see, for example, Debbie Kaminer, Vaccines in the Time of Covid-19: How Government and Businesses Can Help Us Reach Herd Immunity, 103 WIS. L. REV. FORWARD 101, 117-27 (2020).

233. Salzburg Declaration, supra note 13. 
come the cornerstone of the health system, putting emphasis on a conscientious diet featuring individually adapted nutrition, but also big data derived inferences on prevalence and preconditions. ${ }^{234}$

Corporate leadership of the future will, therefore likely not only address hygiene, general healthcare, and crisis management but also put an emphasis on prevention. Corporate medicine requirements will focus rather on the prevention of diseases instead of just trying to reduce financial risks via insurance. In an overall global emergency and restorative medical care cost escalation; corporate managers will need to grow awareness for the efficiency of health promotion and prophylaxis before out-of-control community spread risks within the firm, and key teams or production sites are crippled by prolonged sick leaves. As the coronavirus pandemic is fueled by human interaction and unfavorable health pre-conditions; instead of just curing symptoms, practicing epidemic hygiene will gain momentum to secure a stable, healthy, and sustainable workforce. A growing literature is arguing that the pandemic must be treated by considering the entire context of hygiene, preventive healthcare, and illness from a systems biology perspective focusing on an eco-friendly diet. ${ }^{235}$ In this view, COVID-19 will likely produce a shift towards prevention as a corporate team-learning asset to ease the general healthcare risk of corporations alongside lifting the burden on the healthcare system.

Thus, the development of "healthy human capital" will have to become a priority for firms as a matter of business success in the future. ${ }^{236}$ To that end, firms may take various measures. Ex ante, firms will want to hire employees that do not belong to a risk group because employees who are immune or less likely to fall seriously ill are more likely to remain productive. To the extent legally permissible, they might be interested in employees' genetic predispositions and overall health status as indicators for prevalence, but also environmental conditions, such as living arrangements and social habits. Employees in risk groups but also older labor populations will have a natural disadvantage. ${ }^{237}$ Already now we see that the elderly are $50 \%$ more likely to be laid off during the current pandemic economic fall-out in comparison to the 2008-09 World Financial Recession aftermath. ${ }^{238}$

234. Lauren G. Berlant, Cruel Optimism (2011); Jürgen Vormann, Magnesium: Nutrition and Homoeostasis, 3 AIMS PUB. HeAlTH 329 (2016); Lucy Chen \& Andreas Michalsen, Management of Chronic Pain Using Complementary and Integrative Medicine, 357 BRIT. MED. J. 1284 (2017); Julia Margarete Puaschunder, The Legal and International Situation of AI, Robotics and Big Data with Attention to Healthcare, in REPORT ON BEHALF OF A EUROPEAN PARLIAMENT AGENCY (2019), https://www.researchgate.net/publication/336951897 [https://perma.cc/YQ58-DNG7]; Kuno Hottenrott et al., Exercise Training, Intermittent Fasting and Alkaline Supplementation as an Effective Strategy for Body Weight Loss: A 12-Week Placebo-Controlled Double-Blind Intervention with Overweight Subjects, 10 LIFE 74 (2020).

235. The Great Reset, supra note 62; CDC, supra note 28; UNITED NATIONS, supra note 34.

236. Julia Margarete Puaschunder \& Dirk Beerbaum, Healthcare Inequality in the Digital 21st Century: The Case for a Mandate for Equal Access to Quality Medicine for All, (Sept. 28, 2020) (unpublished manuscript) (on file with author); INT'L MONETARY FUND, supra note 41.

237. See Krista J. Ruffini et al., Who's In and Who's out Under Workplace Covid Symptom Screening? 1112, (Nat'l Bureau of Econ. Rsch., Working Paper No. 27792, 2020), http://www.nber.org/papers/w27792 [https://perma.cc/47GY-L8A6] (noting that screening measures may have an illegal disparate impact on minority groups).

238. Papadopoulos et al., supra note 74; Gwynn Guilford \& Sarah Chaney Cambon, Covid Shrinks the Labor Market, Pushing out Women and Baby Boomers, WALL ST. J. (Dec. 3, 2020, 2:01 PM), https://www.wsj.com/articles/covid-shrinks-the-labor-market-pushing-out-women-and-baby-boomers-11607022074 
As for favorable or unfavorable environmental conditions, those living alone or within a nuclear family will be less susceptible to infection, as will be employees who do not habitually attend gatherings conducive to contagion.

Ex post, corporations may have stronger incentives to monitor and control the behavior of employees. They may require vaccination, but also start integrating health-promoting lifestyles and foster prevention implementation in guided sports events or nutrition seminars as team-building requirements. ${ }^{239}$ The prevention efforts of further coronavirus waves or subsequent pandemics will include measures for the development of the immune system and general resilience through personalized diagnostics and nutrition. Corporate teambuilding and collective learning events may center on nutrition, hygiene, and health monitoring of one's own but also others' health. Employees will be sensitized to detecting unfavorable, risky social norms that may spread the virus. Sick leaves will become a new risk management asset to ward off superspreaders.

In addition, firms will likely use technological innovation to mitigate health risks. ${ }^{240}$ Not only are holistic preventive healthcare measures the clear winners of the COVID-19 crisis; but so are digitization trends that have already emerged prior to the arrival of the novel coronavirus, which now broke the ongoing digitalization market disruption. ${ }^{241} \mathrm{AI}$, algorithms, robotics and big data insights also entered the medical field, which raise medical prevention possibilities to a new digitalized level. ${ }^{242}$ Efficiency, precision, and high quality output are clear advantages of AI, robots and big data in healthcare. ${ }^{243}$ Today's healthcare is, for instance, based on mobile monitoring. More than ever before are AI and the analysis of large amounts of data used to predict, prevent, diagnose, and heal. Analysis of large data allows group behavior prediction and inferences about prevalence and trend forecasts for preventive health care. For example, health apps map the status of the population to contain contagion. Bluetooth tracking of medical aids helps with overcoming bottleneck logistics, prevents corruption, and enables the protection of the privacy of vulnerable patients.

To summarize, it seems likely that a prolonged pandemic means that firms will not only have to develop a more resilient financial structure, but also more resilient human capital by taking health measures for employees. A question that has come up in some countries is whether coordination of health improvement efforts should be subsidized by the public. Employers themselves might otherwise have incentives to underinvest because part of the cost of contagion will be borne by individuals not working for the employer deciding about such measures. In other words, firms will have incentives to take their own bottom line into account when engaging in health management practice but maybe not benefits to the wider public.

[https://perma.cc/4VKF-J2KG].

239. Salzburg Declaration, supra note 13.

240. Julia Margarete Puaschunder, Big Data, ARTIFICIAL InTElligence AND HEALTHCARe 3 (Dieter Feierabend ed., 2019). In the context of COVID-19, see also Michelle M. Mello \& C. Jason Wang, Ethics and Governance for Digital Disease Surveillance, 368 SCIENCE 951 (2020).

241. Puaschunder, supra note 234.

242. Julia Margarete Puaschunder, Stakeholder Perspectives on Artificial Intelligence (AI), Robotics and Big Data in Healthcare: An Empirical Study (Jan. 7, 2020) (unpublished manuscript), https://ssrn.com/abstract=3497261 [https://perma.cc/28N3-KJEN].

243. Puaschunder \& Gelter, supra note 79. 
A possible public policy intervention to counter this possibility is illustrated by the German Prevention Act of 2015, ${ }^{244}$ which emphasizes health in general through preventive means. The government thereby subsidizes corporations to reduce overall healthcare costs and minimize human sickness risks with special attention to support the whole-rounded well-being of vulnerable and minority groups. ${ }^{245}$ According to the Act, employers are encouraged to take measures to diminish the concentration of obesity, diabetes, drugs and drug abuse, and severe previous illnesses, to name a few areas of concern, by shaping lifestyle with eco-friendly consumption, social health risks reduction plans featuring precaution, monitoring team sports, and collective exercise.

\section{ii. Consequences for the Relationship Between Capital and Labor}

It is a more complex question if COVID-19 will affect the relationship between capital and labor by changing the relative bargaining power of those interest groups. Given the different institutional bargaining positions of these groups across countries, we might see quite different outcomes in diverse corporate governance systems. In the previous Section, we have already touched upon the role of workers' different skill levels and types of skills. $^{246}$ The COVID-19 lockdowns and the increasing acceptance of remote work ${ }^{247}$ have added another dimension, namely whether an employee's job can be done remotely or not. Table 1 categorizes jobs in terms of the skill level of employees and the degree of digitization.

Table 1: Classification of Workers in Terms of Level of Skill and Digitization

\begin{tabular}{|c|c|}
\hline High-skill & High-skill \\
Non-digitalized & Digitalized \\
\hline Low-skill & Low-skill \\
Non-digitalized & Digitalized \\
\hline
\end{tabular}

Traditionally, one would expect high-skilled workers to have a higher level of bargaining power (both individually and collectively) because they are harder to replace in a specific firm. ${ }^{248}$ Low-skilled workers that can easily be replaced in the case of long-term

\footnotetext{
244. GESETZ ZUR STÄRKUNG DER GESUNDHEITSFÖRDERUNG UND DER PRÄVENTION (PrÄVEntionsGesetZ-PrÄvG) [LAw to Strengthen HeAlth PROMOTION AND PREVENTION (PREVENTION ACT-PrevG)], July 17, 2015, BundesGesetzBlatt [BGBL I] No. https://www.ilo.org/dyn/natlex/docs/ELECTRONIC/101578/122461/F-43007703/bgbl115s1368_109745.pdf [https://perma.cc/8HN3-GJN9].

245. Id.

246. Supra notes 223-229 and accompanying text.

247. E.g., Annie Gasparro \& Sharon Terlep, Consumer Brands Bet Working from Home Is Here to Stay, WALL ST. J. (Dec. 27, 2020 8:15 PM), https://www.wsj.com/articles/consumer-brands-bet-working-from-homeis-here-to-stay-11609065000 [https://perma.cc/Y7W8-FDJU] (explaining that brands are investing in factories aimed at production for post-pandemic remote workers).

248. E.g., Anat Alon-Beck, Times They Are a-Changin': When Tech Employees Revolt!, 80 MD. L. REV. 120 (2021) (arguing that employees in firms such as Facebook or Google have been able to engage in public-policy
} 
sickness are unlikely to have any bargaining power vis-à-vis their employer.

Groups of skilled employees whose jobs are non-digitalized may come out of the crisis with an advantage (provided they are in a "survivor" industry). Skilled employees in whom the firm has invested considerably are in a better position to insist on protective measures and may use the opportunity to renegotiate working conditions and benefits to their advantage. Such employees may have an enhanced bargaining position if it is more difficult to hire and, most of all, train new workers under social distancing conditions and enhance prevention-attentive group norms.

In such industries where employees have to come together for work coordination, restructuring costs to invest in a pandemic-resistant workspace will likely increase. Each worker will have to do her part to protect the workplace from an outbreak potentially affecting a large number of individuals. In other words, individuals will have an incentive to underinvest in the optimal effort to avoid contagion because part of the cost will be borne by co-workers or remote individuals in the form of greater infection risk. To counter underinvestment, employers either need to engage in potentially costly monitoring or provide compliant employees with rewards. A third, alternative strategy might be to permit health coordination under the aegis of a union. Strengthening employee representation could, however, have the long-run effect of shifting bargaining power from capital to healthy labor.

However, recent experience under pandemic conditions suggests that remote work is more feasible in industries with more highly educated employees. ${ }^{249}$ While such industries may have a greater chance of survival, it is not clear whether this is beneficial for employees. If high-skills jobs have been digitalized and can be performed remotely, employees may have become more easily replaceable because of "social distancing." First, firms will not need to spend as many resources on avoiding contagion in the workplace. Second, with home office work gaining acceptance, employers will likely have access to a large labor pool. Since firms no longer need to hire employees in one geographic region, they will be facing more outside competition. Competing workers may be based in any part of the country, or maybe even the world. To a certain extent, workers may be able to accept jobs in locations remote from the place of living. Overall, this means that such workers will be less dependent on nearby employers, and employers will be less dependent on specific workers located in the vicinity of their places of business. This will not happen if employees' human capital is firm-specific because of the nature of the work. However, if it is firmspecific, largely because of their geographic location, workers and employees will be less tied to each other. Workers in such fields will therefore grow more flexible, with their human capital becoming less firm-specific and more generally applicable. Thus, except in professions where skilled workers are scarce, on the margins we can expect a shift in bargaining power from workers to capital. Consequently, labor bargaining power vis-à-vis their employer will likely be reduced. However, they may also have more outside opportunities.

Overall, it seems likely that we will see a greater bifurcation within the workforce

oriented activism because they are hard to replace due to their specific training).

249. Alexander W. Bartik et al., What Jobs Are Being Done at Home During the COVID-19 Crisis? Evidence from Firm-Level Surveys 3, 8 (Harv. Bus. Sch., Working Paper No. 20-138, 2020), https://www.nber.org/papers/w27422. 
between "digitalized" and "non-digitized" jobs. In the international dimension, possible policy justifications for employee representation would be reduced if employees are less tied to specific employers. However, it is difficult to predict trends for specific jurisdictions. One could speculate that factors-such as language skills-play a role as well. To take a familiar example, the (relatively low-skill) work of telephone customer service has been outsourced to India in English-speaking countries during the past decades. Countries whose languages are not as widely spoken have generally not been subject to this development. To the extent that national languages are still important in higher education jobs, increased home office work may therefore add much less to the fluidity of employer-employee relations.

\section{B. The Return of Nationalism in Corporate Governance}

"Nationalism" or "protectionism" have often been observed in corporate law, and they have generally been criticized by scholars. ${ }^{250}$ Often, policymakers monitor foreign ownership of domestic firms, often because of national security issues. ${ }^{251}$ For example, Western governments have become increasingly concerned about a high reliance on China, for instance regarding critical minerals ${ }^{252}$ and dependence on supply chains in key industriessuch as pharmaceuticals or automotive involving that country. ${ }^{253}$ In the summer of 2020 , the Japanese government tried to set financial incentives for firms to bring key industries

250. Wolf-Georg Ringe \& Ulf Bernitz, Company Law and Economic Protectionism-An Introduction, in COMPANy LAW AND ECONOMic PROTECTIONISM 1 (Ulf Bernitz \& Wolf-Georg Ringe eds., 2011); Pargendler, supra note 14, at 2937.

251. E.g., James A. Lewis, New Objectives for CFIUs: Foreign Ownership, Critical Infrastructure, and Communications Interception, 57 FED. COMMC'NS L.J. 457, 457 (2005) (discussing national security issues in communication firms); Joseph Mamounas, Controlling Foreign Ownership of U.S. Strategic Assets: The Challenge of Maintaining National Security in a Globalized and Oil Dependent World, 13 L. \& Bus. REV. AM. 381, 385-86 (2007) (discussing national security issues raised by foreign ownership in the defense industry); Christopher S. Kulander, Intruder Alert! Running the Regulatory Gauntlet to Purchase, Own, and Operate American Energy and Mineral Assets by Foreign Entities, 46 TeX. TECH L. REv. 995, 997, 1004-07 (2014) (discussing limitations on foreign ownership in the oil and gas industry).

252. Yujia He, The Trade-Security Nexus and U.S. Policy Making in Critical Minerals, 59 Res. PoL. 238, 238 (2018); Exec. Order No. 13817, 83 Fed. Reg. 23295 (Dec. 20, 2017).

253. Joe McDonald, Companies Prodded to Rely Less on China, but Few Respond, AP News (June 29, 2020), https://apnews.com/bc9f37e67745c046563234d1d2e3fe01; Shinzo Abe, Prime Minister of Japan, Speech at Council on Investments for the Future (Mar. 5, 2020), https://japan.kantei.go.jp/98_abe/actions/202003/_00009.html [https://perma.cc/LW2K-5HG8]; EU Trade Chief Urges for More Diverse Supply Chains After Crisis, U.S.News (Apr. 16, 2020, 10:15 AM), https://money.usnews.com/investing/news/articles/2020-04-16/eu-trade-chief-urges-for-more-diverse-supply-chains-after-crisis; Vasileios Theodeosopoulos, The Geopolitics of Supply: Towards a New EU Approach to the Security of Supply of Critical Raw Materials?, in INSTITUTE FOR EUROPEAN STUDIES POLICY BRIEF (2020). 
(automobiles, hygiene products) closer to (Japanese) consumers, but only with mixed success. ${ }^{254}$ Some governments, including the Trump administration, ${ }^{255}$ have rolled out plans to "re-shore" industry. ${ }^{256}$ The arguments for re-shoring range from nationalism to regaining control over the production process, to evading unfavorable loss of control over legislative frames and production standards, given that the internet has made production working conditions around the world transparent, which has in some cases resulted in consumer boycotts. From the individual firm's perspective, proximity to consumers can sometimes provide a competitive edge (as was the case for the fashion empire Zara, which hoped to beat competitors by rolling out new trends and designs quicker) if production can be unethical and consumers can link production to a product and/or brand. ${ }^{257}$ In addition, countries are increasingly seeking to establish domestic ownership and control of multinational firms, especially when foreign ownership has national security implications. ${ }^{258}$

Re-shoring may be possible in some industries but not in others. While traditional industries have re-shored, the internet and big data transfer have become truly international and global, with a large hegemony towards a few corporations and countries holding the power on big data mining and internet connectivity. ${ }^{259}$ The United States but also Nordic

254. Simon Denyer, Japan Helps 87 Companies to Break from China After Pandemic Exposed Overreliance, WASH. POST (July 21, 2020, 6:05 AM), https://www.washingtonpost.com/world/asia_pacific/japan-helps-87companies-to-exit-china-after-pandemic-exposed-overreliance/2020/07/21/4889abd2-cb2f-11ea-99b0-

8426e26d203b_story.html\#: :text=Tokyo\%20bureau\%20chief\%20covering\%20Japan\%2C\%20North\%20Korea\%20and\%20South\%20Korea.\&text=TOKYO\%20\%E2\%80\%94\%20Japan\%20is\%20paying $\% 2087$, an\%20overreliance\%20on\%20Chinese\%20manufacturing [https://perma.cc/H9PK-GNT4]; Julian Ryall, Leave China? No Thanks, Some Japanese Firms Say to Tokyo's Cash Incentives, S. ChINA MoRning Post (May 13, 2020, 7:00 AM), https://www.scmp.com/week-asia/economics/article/3083988/leave-china-no-thanks-some-japanese-firms-say-tokyos-cash? [https://perma.cc/QT54-6A46].

255. Robert E. Lighthizer, The Era of Offshoring U.S. Jobs Is Over, N.Y. TIMES (May 11, 2020), https://www.nytimes.com/2020/05/11/opinion/coronavirus-jobs-offshoring.html [https://perma.cc/MJ4L7XTW]; Andrea Shalal et al., U.S. Mulls Paying Companies, Tax Breaks to Pull Supply Chains from China, REUTERS (May 18, 2020, 12:03 AM), https://www.reuters.com/article/us-usa-china-supply-chains/u-s-mullspaying-companies-tax-breaks-to-pull-supply-chains-from-china-idUSKBN22U0FH; Geoffrey Gertz, How to Deglobalize, FOREIGN POL'Y (July 24, 2020, 4:19 PM), https://foreignpolicy.com/2020/07/24/how-to-deglobalize [https://perma.cc/M7QD-QUNW].

256. The Steam Has Gone out of Globalisation, supra note 35; Special Report on Slowbalisation: Multinational Companies Are Adjusting to Shorter Supply Chains: The Risks of Not Knowing Who Supplies Your Supplier, ECONOMIST (July 11, 2019), https://www.economist.com/special-report/2019/07/11/multinational-companies-are-adjusting-to-shorter-supply-chains [https://perma.cc/9WY6-3EDG].

257. Tony Uphoff, 3 Underreported Trends That Will Accelerate Reshoring, FoRBES (Aug. 24, 2020, 3:10 PM), https://www.forbes.com/sites/tonyuphoff/2020/08/24/3-underreported-trends-that-will-accelerate-reshoring/\#32ee7fe6668e [https://perma.cc/59S7-5EXR].

258. Will TikTok Survive?, ECONOMIST (Sept. 17, 2020), https://www.economist.com/leaders/2020/09/17/will-tiktok-survive [https://perma.cc/SDN8-N3SX] (discussing the Trump administration's effort to establish U.S. control of the social media platform TikTok and suggesting that more governments will demand domestic control of key firms in other industries such as mining). But see Georgia Wells, TikTok Download Ban Is Blocked by Second Judge, WALL ST. J. (Dec. 8, 2020, 12:45 PM), https://www.wsj.com/articles/tiktok-download-ban-is-blocked-by-second-judge-11607390564 [https://perma.cc/V3UW-V7GE] (discussing the District of Columbia District Court's recent injunction against the Trump administration's restrictions on TikTok).

259. Julia Margarete Puaschunder, Dignity and Utility of Privacy and Information Sharing in the Digital Big Data Age, 5 InT'L J. Com. \& Mgmt. Rsch. 62 (2018); Julia Margarete Puaschunder, The Nudging Divide in the Digital Big Data Era, 4 InT’L J. Rsch. Bus. Econ. \& MGMT. 49 (2017). 
countries lead the transition to this new economy. ${ }^{260}$

Another concern with foreign ownership of domestic industry is the potential effect on employment. ${ }^{261}$ While such effects do not necessarily have to be negative, one concern could be that a foreign owner will act differently during an economic downturn. Often large multinational firms are less integrated into and less dependent on domestic political and social networks. Such foreign owners may be less susceptible to local political and economic pressure than, for example, a traditional family or domestic corporate controlling shareholder.

In addition, in recent years a number of powers, most prominently the People's Republic of China, have arguably begun to use investment in other countries, including financial interests in firms, for the purpose of advancing their political influence. ${ }^{262}$ While Western buyers in M\&A transactions typically have economic goals, for Chinese buyers these are frequently mixed with political strategy, including the acquisition of technologies. ${ }^{263}$ Western jurisdictions, as well as those countries that heeded the advice of international organizations, such as the World Bank and IMF, ${ }^{264}$ have opened up themselves for international investment and are, therefore, particularly vulnerable to such influence.

COVID-19 has strengthened economic nationalism ${ }^{265}$ and amplified concerns, espe-

260. Julia Margarete Puaschunder \& Dirk Beerbaum, The Future of Healthcare Around the World: Four Indices Integrating Technology, Productivity, Anti-Corruption, Healthcare and Market Financialization, in RAIS CONF. PROCEEDINGS: 20TH INT'L RAIS CONF. ON SOC. SCI. \& HuMANITIES 164 (2020), http://rais.education/wpcontent/uploads/2020/08/021JPMD.pdf [https://perma.cc/ZVS6-TDXC].

261. E.g., Terry R. Spencer \& Christian B. Green, Foreign Direct Investment in the U.S.: An Analysis of Its Potential Costs and Benefits and a Review of Legislative Tools Available to Shape Its Future Course, 6 TRANSNAT'L L. 539, 553 (1993) (discussing concerns by unions about negative employment effects of foreign ownership); Stephen B. Moldof, Determining What Rules Apply When the Union-Employer Extends Beyond the United States: "Extraterritoriality" - or Convenient Buzzard Used to Avoid Meaningful Analysis?, SV039 ALICLE 457 (2014) (discussing possible downward pressure on U.S. airline employees under foreign ownership). But see Michael Ulan, Should the U.S. Restrict Foreign Investment?, 516 ANN. AM. ACAD. POL. \& Soc. SCI. 117, 122-23 (1991) (criticizing such arguments).

262. See Wesley N. Harris, China Energy: A Crossroads Historiography, 37 T. MARshall L. Rev. 255, 259, 282 (2012); Kent Hughes Butts, Geopolitics of Resource Scarcity, 3 PENN. ST. J.L. \& INT'L AFFs. 1, 6 (2015); Dimitrije Canic, The Balkan Loophole: China's Potential Circumvention of EU Protectionism, 27 U. MIA. BUS. L. REv. 99, 101-17 (2018); Daniel Michaels, Behind China's Decade of European Deals, State Investors Evade Notice, WALL ST. J. (Sept. 30, 2020, 5:30 AM), https://www.wsj.com/articles/behind-chinas-decade-of-europeandeals-state-investors-evade-notice-11601458202 [https://perma.cc/B7NJ-DUSN] (all discussing China's use of financial interests).

263. Gordon \& Milhaupt, supra note 15, at 197-99, 212-13, 218-22.

264. E.g., Zakia Afrin, Foreign Direct Investments and Sustainable Development in the Least-Developed Countries, 10 ANN. SURV. INT'L \& COMPAR. L. 215, 217, 223, 224-25 (2004); Daniil E. Fedorchuk, Acceding to the WTO: Advantages for Foreign Investors in the Ukrainian Market, 15 N.Y. INT'L L. REV. 1, 2, 12, 39 (2002); Asha Kaushal, Revisiting History: How the Past Matters for the Present Backlash Against the Foreign Investment Regime, 50 HARV. INT'L L.J. 491, 505-07 (2009); Tracy A. Kaye, Taxation and Development Incentives in the United States, 62 AM. J. COMPAR. L. 617, 623-26 (2014) (all showing how international organizations have emphasized the advantages of foreign direct investment and put pressure on developing countries to permit it); see generally WORLD BANK GRP., LEGAL FRAMEWORK FOR THE TREATMENT OF FOREIGN INVESTMENT: VOLUME I (1992) (setting guidelines for how countries should approach foreign investment).

265. See Shih, supra note 147, at 84 ("Those developments, combined with the U.S.-China trade war, have triggered a rise in economic nationalism.”). 
cially in the eye of financial liquidity constraints in the real economy caused by the economic fallout of lockdowns. Considerable ownership of domestic firms by Chinese or Russian owners with dominant state influence, or even the sovereign wealth fund of a wealthy OPEC member country, all of a sudden appeared to add "cultural volatility," which blatantly would not be in the best long-run interests of the investee country. ${ }^{266}$ The goal here will often be to ensure a within-country distribution of goods and resources that may be at risk if key actors in firms do not prioritize the national "public interest." Governments will want to ensure that profit-oriented decisions by shareholders do not put these at risk. This is of course not a new concern but can be traced back at least to Walther Rathenau's 1917 argument that shareholders could not be allowed to vote to dissolve a bank that was not particularly profitable but of key importance to the German national economy. ${ }^{267}$

One area where we already see changes is governmental control of FDI. In the United States, a 2018 act $^{268}$ strengthened and expanded the scope of the Committee on Foreign Investment in the United States' (CFIUS) review of FDI, in particular, to include nonpassive, but non-controlling interests. ${ }^{269}$ Likewise, the EU passed a new regulation on the topic in 2019, which came into force in October 2020. ${ }^{270}$ Crucially, Member States must inform each other and the EU Commission of direct investment from outside the EU (even certain investments that do not undergo screening under national law), and they may launch objections in proceedings in each other Member States. ${ }^{271}$ The policy reason is that nonEU investment in one Member State can have an impact on the economies of other Member States. ${ }^{272}$ As was the case in the United States with the expansion of the CFIUS process in recent years, the creation was motivated by increasing investment from China (which itself is comparatively closed to foreign investment or intervention). ${ }^{273}$ In light of COVID-19, Member States have expanded screening requirements and are paying particular attention

266. On such concerns prior to COVID-19, see, for example, Klaus J. Hopt, European Company and Financial Law: Observations of European Politics, Protectionism, and the Financial Crisis, in COMPANY LAW AND ECONOMIC PROTECTIONISM, supra note 250, at 13, 14; on sovereign wealth funds, see Heike Schweizer, Sovereign Wealth Funds-Market Investors or 'Imperialist Capitalists'? The European Response to Direct Investments by Non-EU State-Controlled Entities, in COMPANY LAW AND ECONOMic PROTECTIONISM, supra note 250, at 250, $255-57$.

267. Walther Rathenau, Vom AKTIENWESEN: Eine Geschäftliche Betrachtung [On the Nature OF STOCK: A BusinesS PERSPECTIVE] 39 (1918).

268. Foreign Investment Risk Review Modernization Act of 2018, S. 2098, 115th Cong. (2017) (enacted); Foreign Investment Risk Review Modernization Act of 2017, H.R. 4311, 115th Cong. (2017) (enacted); John S. McCain National Defense Authorization Act for Fiscal Year 2019, Pub. L. No. 115-232, § 101, 132 Stat. 1635, 1635.

269. Gordon \& Milhaupt, supra note 15, at 232.

270. Council Regulation [EU] 2019/452 of the European Parliament and of the Council of 19 March 2019 establishing a framework for the screening of foreign direct investments into the Union, 2019 O.J. (L 79I) 1.

271. Id. at 8; see, e.g., Wolf Zwartkruis \& Bas de Jong, The EU Regulation on Screening of Foreign Direct Investment: A Game Changer?, 31 EUR. BUS. L. REV. 447, 467-70 (2020) (discussing the legal and practical challenges of the EU's regulation on screening foreign direct investment).

272. Zwartkruis \& de Jong, supra note 271, at 469.

273. Jukka Snell, EU Foreign Direct Investment Screening: Europe qui Protege?, 44 EUR. L. REV. 137, 13738 (2019); see also Janina Witkowska, The Attitudes of the European Union and China Towards Foreign Direct Investment: Implications for Bilateral Relations, 22 COMPAR. ECON. RsCH. 84, 93 (2019) (discussing specific examples such as Chinese investment in the port of Piraeus). 
to the healthcare sector. ${ }^{274}$ Likewise, on the verge of leaving the EU's common market, the United Kingdom introduced a bill with a new FDI regime covering seventeen industries. ${ }^{275}$

Given that the playing field may not necessarily be level, many articles of faith held by analysts of corporate law and governance during the past decades are increasingly being called into question. Outright government ownership may not be a good option under many circumstances. Generally speaking, state ownership has had a bad name among scholars of corporate finance and corporate governance during the past decades, for various reasons. ${ }^{276}$ First, the government is usually not motivated by profit, which often results in inefficiencies and lacking incentives to monitor management. ${ }^{277}$ This is an issue most of all when the firm is publicly traded and there are other shareholders besides the government. In the "mixed economy," minority shareholders often have to reckon with an overpowering controlling shareholder against whom legal recourse will often be difficult. ${ }^{278}$ Second, the government as a shareholder often has an impact on the political economy of corporate lawmaking, e.g., by a tendency to favor controlling shareholders in lawmaking. ${ }^{279}$ In recent years, state-owned enterprises (SOEs), where the government holds a controlling stake in

274. E.g., Biancamaria Raganelli \& Federica Marconi, Foreign Investment Screening beyond the COVID19 Challenge: Overcoming the Emergency 14 (Oct. 2020) (unpublished manuscript), https://ssrn.com/abstract=3716488 [https://perma.cc/9XSW-AH5X] ("[T]he Covid-19 pandemic has sped-up the global trend towards increased national protectionism and a stricter screening of foreign direct investments"). Alec Burnside et al., Increased Regulatory Scrutiny of Foreign Direct Investment in the Healthcare Sector, LEXOLOGY (July 28, 2020), https://www.lexology.com/library/detail.aspx?g=bd219a59-a63a-42ec-9811-b3a4df8cd9ad [https://perma.cc/SSK2-7BSQ].

275. National Security and Investment (NSI) Bill 2019-20 HC [210] (U.K.); see Annabelle Timsit, The UK Government Wants New Powers to Block Chinese and Other Foreign Takeovers, QUARTZ (Nov. 13, 2020), https://qz.com/1932426/national-security-and-investment-bill-prevents-foreign-takeovers-of-uk-firms [https://perma.cc/K9QT-NMMH] (discussing the United Kingdom's proposal to review and block M\&As from foreign investors).

276. Andrei Shleifer, State Versus Private Ownership, 12 J. ECON. PERSPS. 133, 133-36 (1998) (discussing the shift in views about public ownership among economists between the 1940s and 1990s); Curtis J. Milhaupt \& Mariana Pargendler, Governance Challenges of Listed State-Owned Enterprises Around the World: National Experiences and a Framework for Reform, 50 CORNELL INT'L L.J. 473, 475 (2017) (discussing Brazil's use of Petrobras to keep down oil prices); but see Ruth Aguilera et al., State Ownership, Political Ideology, and Firm Performance Around the World, 56 J. WoRLD BuS. 101, 113 (2021) (showing that the relationship between profitability and state ownership varies across jurisdictions).

277. E.g., Shleifer, supra note 276, at 137-38 (discussing the trade-off between cost efficiency in quality in choosing between public and private ownership); Nandini Gupta, Partial Privatization and Firm Performance, 60 J. FIN. 987, 988 (2005); Lazzarini \& Musacchio, supra note 221, at 255-56.

278. E.g., Marcel Kahan \& Edward B. Rock, When the Government Is the Controlling Shareholders, 89 TEX. L. REV. 1292, 1323-26 (2011) (discussing possible difficulties of minority shareholders suing in Delaware when the federal government is the controlling shareholders); Michael Firth et al., The Effects of Political Connections and State Ownership on Corporate Litigation in China, 54 J.L. \& ECON. 573, 573 (2011) (finding that politically connected firms in China have a higher chance of succeeding in appeals cases); Donald C. Clarke \& Nicholas C. Howson, Pathway to Minority Shareholder Protection: Derivative Actions in the People's Republic of China, in The Derivative ACTION IN ASIA: A COMPARATIVE AND FunCTIONAL APPROACH 243, 247, 254-57 (Daniel Puchniak et al., eds., 2012) (discussing the courts' reluctance to challenge the communist party in the corporate context).

279. E.g., Pargendler, supra note 14, at 2925-42 (describing how the position of the Brazilian government as a controlling shareholder affected corporate law in general). 
a publicly-traded firm, are again on the rise around the world. ${ }^{280}$

While many Western countries retreated from government ownership since the 1980s, some jurisdictions, such as China or Singapore (and Western countries during an earlier period), have grown their economy by using it as a strategic tool to prop up firms as national champions before exposing them to competition. ${ }^{281}$ With the 2008-09 financial crisis, government ownership returned to a certain extent, even in the United States, where the government-held stakes in firms that had been bailed out temporarily. Pressure to bail out companies will likely return with COVID-19, for example in the aviation industry. Like banks, airlines provide key infrastructure to the broader economy, as the presence of a hub in a city makes it more attractive as a location for international or regional corporate headquarters. The United States CARES Act of 2020 permits and, in certain cases, requires the government to take equity interests or warrants when bailing out certain corporations, especially in the airline industry and business critical to national security. ${ }^{282}$ Independently from COVID-19, Attorney General William Barr suggested that the U.S. government could buy a stake in Nokia or Ericsson to counter Huawei in the ongoing struggle for the $5 \mathrm{G}$ mobile network market. ${ }^{283}$ In many other countries, we will likely see a return of government ownership and control, for better and for worse. The COVID-19 crisis has already prompted countries such as Argentina ${ }^{284}$ and France ${ }^{285}$ to initiate at least temporary government control of certain firms, in part to save them, in part to secure the preservation of a key industry. ${ }^{286}$ EU competition commissioner Margrethe Vestager has urged EU Member States to obtain stakes in ailing firms to prevent them from being taken over by Chinese

280. Lazzarini \& Musacchio, supra note 221, at 255; Milhaupt \& Pargendler, supra note 276, at 474.

281. See generally Ha-JoOn Chang, Kicking aWAY THE LADDER: DeVElopment STRATEgy IN HISTORICAL PERSPECTIVE (2002) (describing how modern wealthy countries utilized different strategies for economic growth than the strategies recommended to developing countries today); see also Richard Baldwin, Trade and Industrialization after Globalization's Second Unbundling, in GLOBALIZATION IN AN AGE OF CRISIS: Multilateral ECONOMiC COOPERATION IN THE TwENTY-First CENTURY 165, 171-73 (Robert C. Feenstra \& Alan M. Taylor eds., 2013); Baldwin, supra note 138, at 24 (both noting that before globalization of supply chains, countries would have to industrialize to become competitive, while afterwards they could benefit by joining a supply chain); see also Milhaupt \& Pargendler, supra note 276, at 518-29 (discussing Singapore's and China's experience with SOEs); Lars Sorgard, The Economics of National Champions, 3 EUR. COMPETITION J. 49, 49-50 (2007) (discussing the shift from national champion policies to open market policies in Europe); Paul Guest \& Dylan Sutherland, The Impact of Business Group Affiliation on Performance: Evidence from China's 'National Champions', 34 CAMBRIDGE J. ECON. 617, 617 (2010) (exploring the business success of China's national champions).

282. Coronavirus Aid, Relief, and Economic Security Act, Pub. L. No. 116-136, § 4003(d) (2020).

283. Really? Is the White House Proposing to Buy Ericsson or Nokia?, N.Y. TIMES (Feb. 7, 2020), https://www.nytimes.com/2020/02/07/business/dealbook/bill-barr-huawei-nokia-ericsson.html [https://perma.cc/Q6NM-HQ4P].

284. Amy Guthrie, Argentina Attempts to Nationalize Grains Processor During COVID-19, LAw.COM (June 15, 2020, 3:16 PM), https://www.law.com/international-edition/2020/06/15/argentina-attempts-to-nationalizegrains-processor-during-covid-19/?slreturn=20200709230456 [https://perma.cc/2DDT-GG7A].

285. France to Temporarily Nationalize Companies Hit by Covid-19, TELESUR News (Apr. 3, 2020), https://www.telesurenglish.net/news/France-To-Temporarily-Nationalize-Companies-Hit-by-COVID-1920200403-0014.html [https://perma.cc/9KUS-6FZ3].

286. A somewhat less intrusive method is to command private businesses to produce certain products, which, for example, the U.S. government can do (and has done) under the Defense Production Act of 1950, 50 U.S.C. § 4558 (2018). 
rivals during the pandemic. ${ }^{287}$ The EU countries as well as the United Kingdom are at least considering the option of nationalization in order to save ailing companies. ${ }^{288}$ Law firms have warned their multinational corporation clients against an increasing risk of both open and "stealth" nationalization. ${ }^{289}$

There are other, less intrusive means for the government to pursue specific policies with firms, including to avoid foreign influence in firms. Most prominently, many countries have often employed so-called "Golden Shares" in privatized companies, in which the government had key rights to influence corporate policies, or at least veto rights, as long as they held a specific minority of shares. Regardless of whether these instruments were enshrined in law or corporate charter, in a large number of decisions during the late 1990s and 2000s, the Court of Justice of the European Union (CJEU) has held almost all "Golden Shares" to be a violation of the free movement of capital because they were liable to discourage cross-border investment. ${ }^{290}$ In one case, Commission v. Belgium, ${ }^{291}$ the provision was upheld, as the court found that "the objective pursued by the legislation at issue, namely the safeguarding of energy supplies in the event of a crisis, falls undeniably within the ambit of a legitimate public interest," as the government's veto power was limited to certain strategic assets. ${ }^{292}$

While the court's jurisprudence is not likely to change as a matter of principle, one could imagine that countries will try to find new designs for such instruments to work around the case law. Moreover, with the COVID-19 crisis and increasing debates about problems of international investment, the argument supporting the qualification of a particular instrument - as justified in the public interest in the context of the court's proportionality test - may shift to a certain extent in favor of governments seeking to preserve a national influence on key industries. Operating under changed circumstances, the CJEU may become more amenable to national influence than it was a generation ago. Countries outside the European Union are, of course, not subject to the constraints imposed by European treaties and may therefore employ Golden Shares quite freely.

An example of legislative development in this area is the Italian "Golden Power" law

287. Javier Espinoza, Vestager Urges Stakebuilding to Block Chinese Takeovers, FIN. TIMES (Apr. 12, 2020), https://www.ft.com/content/e14f24c7-e47a-4c22-8cf3-f629da62b0a7 [https://perma.cc/K59W-3HCT].

288. Thomas Kohlmann, Coronavirus Forces EU Leaders to Weigh Nationalization Options, DeUTSCHE WELLE (Mar. 19, 2020), https://www.dw.com/en/coronavirus-forces-eu-leaders-to-weigh-nationalization-options/a-52838689 [https://perma.cc/EZ6D-NJWB]; Alissa Kole Amico, Government Ownership in a Post Virus World, HARVARD L. SCH. F. ON CORP. GOVERnANCE (Apr. 12, 2020), https://corpgov.law.harvard.edu/2020/04/12/government-ownership-in-the-post-virus-world/ [https://perma.cc/QBY4-AHQX].

289. BAKER MCKENZIE, PRESERVE, PROTECT, AND DEFEND: GLOBAL NATIONALIZATION RisK: PRACTICAL CONSIDERATIONS FOR INVESTORS 5-7 (2020).

290. E.g., Comm'n v. France, 2002 E.C.R. C-483/99; Comm'n v. Belgium, 2002 E.C.R. C-503/99; Comm'n v. Portugal, 2002 E.C.R. C-367/98 (finding that "Golden Shares" violate principles of free movement of capital); among others, see also the subsequent "Volkswagen" case of Comm'n v. Germany, 2007 E.C.R. C-112/05 (holding that the Volkswagen Act of 1960 violated the Treaty on the Functioning of the European Union). See, e.g., Wolf-Georg Ringe, Company Law and Free Movement of Capital, 69 CAMBRIDGE L.J. 378-409 (2010) (discussing how company law can potentially be subjected to EU law); Pargendler, supra note 135, at 554; Martin Gelter, EU Company Law Harmonization Between Convergence and Varieties of Capitalism, in RESEARCH HANDBOOK ON THE HISTORY OF COMPANY AND CORPORATION LAW 323, 333 (Harwell Wells ed. 2018).

291. Comm'n v. Belgium, 2002 E.C.R. C-503/99.

292. Id. at II 46; Ringe, supra note 290, at 384. 
of 2012, which allows the government to intervene in acquisition in the defense, energy, transportation, communication, and high-tech sectors. ${ }^{293}$ Thus, it can block acquisitions, veto shareholder resolutions, and impose specific conditions relating, among others, to technology and data transfers for national defense and security reasons. ${ }^{294}$ At least until the end of the pandemic, the government's screening powers were extended to cover the financial industry, raw materials, and food security, as well as access to sensitive information and media. The amendment governs even the acquisition of controlling interests by companies from other EU member states. ${ }^{295}$

Takeover law has also often been employed as an instrument to shield firms from unwanted influence, which includes possible foreign takeovers. Besides antitrust approval, ${ }^{296}$ the key gatekeeper to a takeover is often the company itself, with the key question being who decides about the sale of the firm to the bidder. In jurisdictions with concentrated ownership, the bidder would typically have to persuade large shareholders to sell. Financially motivated shareholders will sell if the price is good (and it will likely include a premium over the market price paid to outside investors). However, countries may encourage the creation or persistence of a noyaux durs ("hard core") of shareholders - as France has historically done $\mathrm{e}^{297}$ —with non-financial motivations to maintain the firm within national control. These could be the government itself, families, or other firms from the country that are deeply embedded into the local economic and political network. Arguably, the mandatory bid rule, which many countries around the world have adopted during the past twenty years at least in watered-down form, may help to entrench such a structure. $^{298}$ This rule - which has its origins in the UK and was implemented in art. 5 of the EU Takeover Directive ${ }^{299}$ _requires that the acquirer of control must offer to pick up the minority shareholders' stock for the best price paid during a particular period prior to the acquisition of control. ${ }^{300}$ This will deter bids because an acquirer that succeeds in wedging

293. Francesca Toricelli \& Pietro Missanelli, Italian Law: Corporate Transparency and 'Golden Power' Provisions in Emergency Legislation for Coronavirus Disease 2019, NAT'L L. REv. (Apr. 23, 2020), https://www.natlawreview.com/article/italian-law-corporate-transparency-and-golden-power-provisions-emergency-legislation [https://perma.cc/Z4DL-5DMJ] (discussing sectors in which amendments to the "Golden Power" apply).

294. D.L. 15 marzo 2012, n.21, G. U. Mar. 16, 2012, n.63 (It.).

295. D.L. 8 aprile 2020, n.23, G. U. Apr. 9, 2020, n.94 (It.); see, e.g., Simon Clark \& Ben Dummett, Coronavirus Accelerates European Efforts to Block Foreign Takeovers, WALL ST. J. (Apr. 10, 2020), https://www.wsj.com/articles/coronavirus-accelerates-european-efforts-to-block-foreign-takeovers-

11586516403 [https://perma.cc/BE75-7S86] (detailing the acceleration of protectionism during the pandemic); Toricelli \&Missanelli, supra note 293.

296. Anu Bradford et al., Is E.U. Merger Control Used for Protectionism? An Empirical Analysis, 15 J. EMPIRICAL LEGAL STUD. 165, 165 (2018) (finding that EU antitrust law is not systematically used for protectionist purposes).

297. E.g., James A. Fanto, The Role of Corporate Law in the Adaptation of French Enterprises, 1998 Colum. Bus. L. REv. 97, 107-08 (1998) (outlining the French history of noyaux durs); Clift, supra note 126, at 550-52 (detailing "France's protected financial network economy").

298. Marco Ventoruzzo, Takeover Regulation as a Wolf in Sheep's Clothing: Taking U.K. Rules to Continental Europe, 11 U. PA. J. Bus. L. 135, 140 (2008).

299. Directive 2004/25/EC of the European Parliament and of the Council of 21 April 2004 on takeover bids, 2004 O.J. (L 142) 12, https://eur-lex.europa.eu/legal-content/EN/TXT/?uri=celex\%3A32004L0025 [https://perma.cc/9X68-78FN].

300. On the origins of the rule see, for example, Martin Gelter \& Alexandra M. Reif, What Is Dead May 
a member of the noyaux durs out of the coalition would likely be able to cough up the funds to purchase a considerably higher percentage of the firm's shares. ${ }^{301}$

When a company's stock is widely held, dispersed investors will likely be inclined to accept a tender offer based on price. Thus, the key question is often whether and how boards can defend against a hostile bid. Such bids are often highly controversial because they pit the interests of financial investors against those of management and workers. ${ }^{302} \mathrm{In}$ the United States, many states have implemented antitakeover statutes facilitating defenses or otherwise inhibiting hostile bids, ${ }^{303}$ and the Delaware courts scrutinize the board's actions relatively lightly with the Unocal test. ${ }^{304}$ Thus, one could already characterize the U.S. takeover policy as potentially nationalistic. Reportedly, the pandemic has already resulted in an increasing number of poison pill adoptions by corporate boards. ${ }^{305}$

By contrast, many other jurisdictions have transplanted the United Kingdom's passivity (or neutrality) rule, which prohibits most effective defensive actions. ${ }^{306}$ The EU Takeover Directive made the neutrality rule optional, and a number of major countries, including Germany, did not implement it as such. ${ }^{307}$ Arguably, Continental European countries that did introduce it typically did not have more than a handful of firms with dispersed ownership, thus making the rule irrelevant in practice. ${ }^{308}$ Nevertheless, the concern of firms being taken over by overseas competitors after the financial crisis led a number of countries to abandon the mandatory board neutrality rule. ${ }^{309}$ France adopted the neutrality rule, but also implemented the reciprocity exception permitted by the Directive, which allows firms not to apply neutrality when faced with a bidder not subject to neutrality itself;

Never Die: The UK's Influence on EU Company Law, 40 FORDHAM INT'L L.J. 1413, 1428-29 (2017) (detailing the conditions leading to the mandatory bid rule).

301. See Lucian Arye Bebchuk, Efficient and Inefficient Sales of Corporate Control, 109 Q.J. Econ. 957, 971-72 (1994) (modeling the deterrent effects of the mandatory bid [or "equal opportunity"] rule on takeovers).

302. E.g., Mark J. Roe, Takeover Politics, in The DeAl DeCADE 321, 339 (Margaret M. Blair ed. 1993) (discussing how takeover politics affected corporate performance and changed relationships between corporate management and financial markets); M. Pagano \& P.F. Volpin, Managers, Workers, and Corporate Control, 60 J. FIN. 841, 841 (2005).

303. E.g., AlLEN \& KRAAKMAN, supra note 86, at 605-10.

304. See generally Unocal v. Mesa Petroleum Co., 493 A.2d 946 (Del. 1985) (stating the Unocal test).

305. Gail Weinstein, et al., A Turn Back to "Poison Pills" in Response to the Coronavirus Pandemic, HARV. L. SCH. F. ON CORP. GOVERNANCE (Apr. 9, 2020), https://corpgov.law.harvard.edu/2020/04/09/a-turn-back-topoison-pills-in-response-to-the-coronavirus-pandemic [https://perma.cc/D67C-C9YH]; Enriques, supra note 222 , at 271.

306. Panel on Takeovers And Mergers, The City Code On TAKeovers and Mergers, R. 21.1(a) (8th ed. 2006), https://www.thetakeoverpanel.org.uk/wp-content/uploads/2008/11/code.pdf?v=7Nov2019 [https://perma.cc/A23W-HCPD] (prohibiting any frustrating action by the offeree company's board without shareholder consent once a bona fide bid has materialized).

307. Guido Ferrarini \& Geoffrey P. Miller, A Simple Theory of Takeover Regulation in the United States and Europe, 42 CORNELL J. INT'L L. 301, 321-23 (2009) (discussing the German implementation). An EU report of 2013 found that Belgium, Denmark, Germany, Hungary, Luxembourg, the Netherlands, and Poland did not implement the (optional) passivity rule. EU COMM'N, THE TAKEOVER BIDS DiRECTIVE ASSESSMENT REPORT 6466 (2013); see also Paul Davies et al., The Takeover Directive as a Protectionist Tool?, in COMPANY LAW AND ECONOMIC PROTECTIONISM, supra note 250, at 105, 135-38 (surveying transposition choices).

308. Ferrarini \& Miller, supra note 307, at 331. But see Davies et al., supra note 307, at 121-22 (surveying transportation choices).

309. Davies et al., supra note 307, at 142 (discussing Italy and Hungary). 
in addition, the law made defense warrants available to firms, ${ }^{310}$ which bear some resemblance to the U.S. poison pill and potentially function as a takeover defense. ${ }^{311}$

Many countries also allow for "structural" takeover defenses that are put into place not ex post in reaction to a bid, but ex ante in anticipation of possible bids. France's famous "Florange" law of 2014 made so-called loyalty shares, where long-term stockholders have additional voting rights, the default for all publicly traded firms. ${ }^{312}$ The law was introduced in reaction to the closure of a France plant of Arcelor, a former French "national champion" that had been acquired by the Indian conglomerate Mittal. ${ }^{313}$ The protectionist motivation is obvious in this case.

Takeover law is often dominated by interests that are salient to politicians in the jurisdiction in question. Management and labor will favor takeover defenses, while outside investors will oppose it. Thus, the political economy will only weigh in favor of hostile bids where institutional investors are a powerful interest group, such as in the United King$\mathrm{dom}^{314}$ (outside of jurisdictions where the rule does not matter because of concentrated ownership). Following up on the trend of recent years, with COVID-19 we are likely to see more movement toward an anti-takeover position, especially where changes favor domestic interest groups.

First, we may see additional countries edging away from the neutrality rule and permitting takeover defenses. Early in the pandemic, the depressed stock market raised the concern that foreign bidders could acquire European firms, among others, at bargain prices. ${ }^{315}$ This concern has not entirely abated, even in the United States, as some firms are still suffering from depressed stock prices. ${ }^{316}$ In the long run, management and unions will continue to clamor for the preservation of jobs. In addition, the argument of the necessity to keep key industries within national control may make more countries abandon the passivity rule in favor of strengthening takeover defenses. Second, regulators will be tempted to permit deviations from the mandatory bid rule, for example, to orchestrate a domestic bailout of a financially distressed company. ${ }^{317}$

Finally, a number of non-corporate supranational anti-protectionist policies are also likely to come under renewed scrutiny. In the EU, two key areas of law seek to establish a level playing field. First, state aid law restricts national subsidies to narrow circumstances. ${ }^{318}$ The policy is intended to prevent Member States from interfering with market

310. CODE DE COMMERCE arts. L 233-32(II), L 233-33.

311. Davies et al., supra note 307, at 148 .

312. Loi 2014-384 du 29 mars 2014 visant à reconquérir l'économie réelle [Law 2014-384 of March 29, 2014 Aiming to Reconquer the Real Economy], Journal OfFiciel DE LA RePubliQue Française [J.O.] [OfFicial GaZeTte OF FranCE] Apr. 1, 2014, p. 0077.

313. Pargendler, supra note 135 , at 543.

314. John Armour \& David A. Skeel, Jr., Who Writes the Rules for Hostile Takeovers, and Why? -The Peculiar Divergence of U.S. and U.K. Takeover Regulation, 95 GEO. L.J. 1727, 1767-76 (2007) (identifying institutional investors as the key interest group behind the UK City Code).

315. Clark \& Dummett, supra note 295.

316. Kai Liekefett, The Comeback of Hostile Takeovers, HARV. L. SCH. F. ON CORP. GovernANCE (Nov. 8 , 2020), https://corpgov.law.harvard.edu/2020/11/08/the-comeback-of-hostile-takeovers [https://perma.cc/Z5HYBNWB].

317. See Enriques, supra note 222, at 266 (discussing the availability of such exemptions in European countries and their permissibility under the Takeover Directive).

318. Consolidated Version of the Treaty on the Functioning of the European Union art. 107(1), May 9, 2008, 
operations by selecting winners and from competing with each other on subsidies. ${ }^{319}$ The Treaty exempts "aid to make good the damage caused by natural disasters or exceptional occurrences, ${ }^{, 320}$ and the EU Commission has already determined that COVID-19 falls under this provision. For example, Member States are aiding flagship carriers, likely to the detriment of other airlines. ${ }^{321}$ The United Kingdom's desire to leave the EU's state aid regime after the 2020 transition period in order to subsidize companies was one of the most contentious issues in the Brexit negotiations. ${ }^{322}$

Second, EU public procurement law sets up procedural requirements binding the Member States and prohibiting preferences for domestic bidders. ${ }^{323}$ The Commission has issued guidance stating, among other things, that public buyers could use an emergency procedure to negotiate directly with a contractor and avoid publication. ${ }^{324}$ Inside and outside the EU, the temptation has risen for politicians to award public contracts without a

2008 O.J. (C 115) [hereinafter TFEU] ("Save as otherwise provided in the Treaties, any aid granted by a Member State or through State resources in any form whatsoever which distorts or threatens to distort competition by favouring certain undertakings or the production of certain goods shall, in so far as it affects trade between Member States, be incompatible with the internal market.").

319. E.g., Ruth Mason, Identifying Illegal Subsidies, 69 AM. U. L. Rev. 479, 488-89 (2019) (explaining that the prohibition of state aid within the EU prevents protectionism and retentionism).

320. TFEU, supra note 318, at art. 107(2)(b).

321. Communication from the Commission: Temporary Framework for State Aid Measures to Support the Economy in the Current COVID-19 Outbreak, 2020/C 91 I/01, 2020 O.J. (C 91I); see also Saim Saeed, Ryanair Goes to War Against Coronavirus Bailouts, Politico (May 12, 2020, 5:45 PM), https://www.politico.eu/article/ryanair-goes-to-war-against-coronavirus-bailouts (discussing government bailouts of flagship carriers that possibly violate state aid rules); The European Union Is Having a Bad Crisis, ECONOMIST (May 14, 2020), https://www.economist.com/leaders/2020/05/14/the-european-union-is-having-a-bad-crisis

[https://perma.cc/E9M2-GWTX] (reporting that "[state aid rules] have been suspended as governments pour $€ 2$ trn (\$2.2trn) into saving businesses from collapse").

322. Wolfgang Münchau, The Risk of a No-Deal Brexit Is Rising, and That's No Bad Thing, Fin. TIMES (Aug. 23, 2020), https://www.ft.com/content/46087061-3fa7-4bd2-9f0d-d130fa58a409 [https://perma.cc/XH8DCG2N]; Max Colchester \& Laurence Norman, Boris Johnson Wants Scope to Boost Government Intervention, Rattling Brexit Talks, WALL ST. J. (Sept. 8, 2020, 9:30 AM), https://www.wsj.com/articles/boris-johnsons-planto-pick-business-winners-stalls-brexit-talks-11599559858 [https://perma.cc/RNW5-ZP3Z]. The final agreement requires the United Kingdom to establish a robust state-aid regime but will give it more flexibility relative to EU law. Trade and Cooperation Agreement Between the European Union and the European Atomic Energy Community, and the United Kingdom of Great Britain and Northern Ireland, Part Two, Title XI, Ch. 3 (pending ratification), available at https://ec.europa.eu/info/sites/info/files/brexit_files/info_site/tca-20-12-28.pdf [https://perma.cc/P2HJ-5VMR]. See, e.g., George Peretz, The Subsidy Control Provisions of the UK-EU Trade and Cooperation Agreement: A Framework for a New UK Domestic Subsidy Regime, EU RELS. L. BLOG (Dec. 28, 2020), https://eurelationslaw.com/blog/the-subsidy-control-provisions-of-the-uk-eu-trade-and-cooperationagreement-a-framework-for-a-new-uk-domestic-subsidy-regime [https://perma.cc/RXD7-YDD6].

323. Directive 2014/24/EU of the European Parliament and of the Council of 26 Feb. 2014 on Public Procurement and Repealing Directive 2004/18/EC, 2014 O.J. (L 94) 65; Directive 2014/25/EU of the European Parliament and of the Council of 26 Feb. 2014 on Procurement by Entities Operating in the Water, Energy, Transport, Postal Services Sectors, and Repealing Directive 2004/17/EC, 2014 O.J. (L 94) 243; Directive 2014/23/EU of the European Parliament and of the Council of 26 Feb. 2014 on the Award of Concession Contracts, 2014 O.J. (L 94) 1.

324. Communication from the Commission Guidance from the European Commission on Using the Public Procurement Framework in the Emergency Situation Related to the COVID-19 Crisis, 2020 O.J. (C 108) I/1 (referring to Art. 32 of Directive 2014/24/EU). 
transparent tender procedure, often to meet emergency demands. ${ }^{325}$ In countries outside the EU, these similar requirements are much less of a hurdle, but we are likely to see pressure to alleviate these strict requirements within Europe, to the disfavor of firms - both from inside and outside the common market.

\section{The Return of "Stakeholderism"}

The third area where we are likely to see change is the principle of "shareholder primacy" as such. During the past few decades up to the 2008-09 financial crisis, a shareholder wealth orientation had been on the ascendancy, whereas stakeholder models were typically considered inefficient aberrations by mainstream corporate law theory, most of all in the United States. As discussed above, the creeping abandonment of shareholder primacy began in the early 2010s. ${ }^{326}$ The trend reached a high point with the August 2019 statement by the Business Roundtable in the United States, which argues that corporations should work for the benefit of all stakeholders, including customers, employees, suppliers, communities, and shareholders. ${ }^{327}$ The American Law Institute, under the leadership of Professor Edward Rock, is currently pursuing a project to draft a Restatement of Corporate Governance, ${ }^{328}$ which will at least investigate a pluralist conception of corporate law. ${ }^{329}$ A growing number of firms have begun to include ESG criteria (Environmental, Social, Governance) in executive compensation. ${ }^{330}$

In addition to changes in the interaction between capital and labor outlined in Section IV.A.3 above, we argue that there are two current aspects of public policy in corporate law that are closely related to COVID-19. Section IV.C.1 discusses the growing debate about inequality, and how it affects business. Section IV.C.2 addresses the impact of climate change and growing pressures for companies to improve their environmental practices.

325. E.g., Bimpe Archer, Randox Awarded Covid-19 Testing Contract Without Tender Under Emergency Measures, IRISH NEWS (May 12, 2020), http://www.irishnews.com/coronavirus/2020/05/12/news/randoxawarded-covid-19-testing-contract-without-tender-under-emergency-measures-1934820

[https://perma.cc/GQ2E-WDBZ]; Firms Given £1bn of State Contracts Without Tender in Covid-19 Crisis, GUARDIAN (May 15, 2020), https://www.theguardian.com/world/2020/may/15/firms-given-1bn-of-state-contracts-without-tender-in-covid-19-crisis [https://perma.cc/6RQ3-5887]; Dokumente zum Entwicklungsauftrag der "Corona-Warn-App" durch SAP und Telekom [Documents on the Development Order for the "Corona Warning App" by SAP and Telekom], FRAGDENSTAAT, https://fragdenstaat.de/anfrage/dokumente-zum-entwicklungsauftrag-der-corona-warn-app-durch-sap-und-telekom [https://perma.cc/W432-U8K7] (freedom of information request to the German Ministry of Health finding that no public tender procedure was conducted for a COVID19 tracking app); Laurence Folliot Lalliot \& Christopher R. Yukins, COVID-19: Lessons Learned in Public Procurement. Time for a New Normal?, CONCURRENCES, No. 3-2020, at 46, 47-48 (discussing emergency procurement measures in France).

326. Supra notes 132-136 and accompanying text.

327. Bus. RoundTABLE, supra note 22 .

328. Four Restatement Projects Launch, AM. L. INST. (Jan. 28, 2019), https://www.ali.org/news/articles/fourrestatement-projects-launch/ [https://perma.cc/J8RL-5DAY].

329. Lucian A. Bebchuk \& Roberto Tallarita, The Illusory Promise of Stakeholder Governance, CORNELL L. REV. (forthcoming Dec. 2020) (n. $\dagger$ ), https://ssrn.com/abstract=3544978 [https://perma.cc/L2E8-TMSZ] (noting that the ALI's "project on the Restatement of the Law, Corporate Governance . . . is examining the subjects of corporate purpose and social responsibility").

330. Stavros Gadinis \& Amelia Miazad, Corporate Law and Social Risk, 73 VAND. L. Rev. 1401, 1419 (2020). 
Section IV.C.3 argues that corporate governance will have to consider stakeholder issues to preserve its public legitimacy.

\section{Inequality}

Historically, crises have always been drivers of socio-political change. ${ }^{331}$ The COVID-19 pandemic in particular has sparked social criticism and protests around the world against the existing status quo. ${ }^{332}$ Building on already rising trends, strict COVID19 curfews in all major economies had the side effect of mobilizing the population against injustice and inequality around the world. ${ }^{333}$ In the wake or aftermath of strict lockdowns all over the world, protests arose against state interference in the privacy and freedom of individuals, but also against social inequality and for promoting climate justice. Online communities had fierce debates about long-held wishes for a fairer, more equal, just, and sustainable world.

COVID-19 has exacerbated inequality, if considering the current divide between winning and losing industries or the rising gap between financial markets and the real economy, which has also drawn public attention lately. Concerns about growing inequality have increasingly been discussed since the 2008-09 world financial recession, which was particularly hard on minorities. ${ }^{334}$ Already now we can detect that the impetus of the novel coronavirus hits the poor and vulnerable, including low-skilled workers and refugees, unequally hard when it comes to infection rates, seriously-critical symptoms and unfavorable disease trajectories, economic fall-outs in declined income, furloughs or job insecurity, and/or degraded lifestyles due to the lack of personal space, mobility, connectivity, and quality of life. ${ }^{335}$ Both the human and financial cost appear to fall more heavily on those disfavored in the economic system already. ${ }^{336}$

In addition, the pandemic initially had a considerable impact on the stock market, which raises concerns in places where employees saw their invested retirement wealth eviscerated, such as the United States. While the market caught up to its previous levels by the late summer of 2020 and rose to all-time highs during the final quarter of 2020, a lot of

331. See generally NaOMi Klein, The SHock Doctrine: The Rise OF Disaster CAPITAlism (2007) (analyzing how crises lead to change).

332. E.g., The Year When Everything Changed, ECONOMIST (Dec. 19, 2020), https://www.economist.com/leaders/2020/12/19/the-year-when-everything-changed [https://perma.cc/C7ZE-YNTQ] ("[T]he pandemic has highlighted injustice.").

333. Raj Chetty et al., Income Segregation and Intergenerational Mobility Across Colleges in the United States, 135 Q.J. ECON. 1567, 1567-633 (2020); See generally BRANKo MILANOVIC, GLOBAL INEQUALITY: A New ApProach for the Age of Globalization (2016); Thomas Piketty, CaPital in the Twenty-First CENTURY (Arthur Goldhammer trans., 2014). On trends during the pandemic, see Raj Chetty \& Markus Brunnermeier, Raj Chetty on the Economic Impacts of COVID-19: Real-Time Evidence from Private Sector Data, PRINCETON UnIV. BENDHEIM CTR. FOR FIN. (June 17, 2020, 12:30 PM), https://bcf.princeton.edu/events/rajchetty-on-the-economic-impacts-of-covid-19-real-time-evidence-from-private-sector-data/.

334. See generally AnNe CASE \& ANGus Deaton, Deaths of DeSPair AND the Future of CAPitalism (2020) (examining the effects of recessions and economic fallouts on minorities).

335. Martina Björkman Nyqvist et al., COVID-19 Amplifies Inequality: Fight Back with Long-Term Thinking, WORLD ECON. F. (July 15, 2020), https://www.weforum.org/agenda/2020/07/covid-19-amplifies-inequalityfight-back-with-long-term-thinking/ [https://perma.cc/GDU7-YDDY].

336. Papadopoulos et al., supra note 74. 
uncertainty remains. This adds to the fact that many $401(\mathrm{k})$ plans contain woefully inadequate amounts of savings. ${ }^{337}$ The market impact of COVID-19, as well as the fact that many will withdraw money from pension plans early after the disruption of their livelihood, ${ }^{338}$ will likely mean that the percentage of workers with inadequate retirement savings will increase; minorities may be disproportionately negatively affected in the long-run, while their savings dissipate in expected inflation and negative interest rate climates. ${ }^{339}$ Median voter preferences may thus shift away from emphasizing the protection of shareholders. $^{340}$

Policymakers will therefore feel pressure to support the middle-class-likely in their role as workers with specific skillsets rather than as "forced capitalists" holding stock in anticipation of retirement. ${ }^{341}$ One proposal in the corporate governance area is to put worker representatives on boards. Many European countries, most prominently Germany, have had employee representation of codetermination systems for decades. ${ }^{342}$ While their economic effects are frequently studied and much disputed-benefits for human capital development are discussed but disputed ${ }^{343}$ - it is intuitive that workers on the board can have the effect of shifting the distribution of corporate rents away from shareholders towards employees. ${ }^{344}$

In this vein, employee representation on the board of directors, which had long been on the defense in corporate law policy debates, seems to be making gains again. Most prominently, France expanded its employee representation requirement (which was previously limited to certain public sector and privatized firms) in June 2013 in some private firms, and further extended it in 2015 to those firms with one thousand employees in France or five thousand employees worldwide. ${ }^{345}$ Even in English-speaking countries, board-level

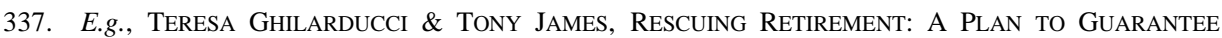
RETIREMENT SECURITy FOR All AmERICANS 3, 31-36 (2020); Brian Anderson, Index Reveals Americans' Heightened Worries Around Retirement, 401K Specialist MaG., (July 21, 2020), https://401kspecialistmag.com/index-reveals-americans-heightened-worries-around-retirement [https://perma.cc/ECE8-YL27].

338. In addition, the CARES Act, $§ 2202$ permits early distributions from retirement plans without a tax penalty under certain circumstances. Coronavirus Aid, Relief, and Economic Security Act (CARES) Act of 2020, Pub. L. No. 116-136, § 2202, 134 Stat. 281, 340.

339. Monique Morrissey, The State of American Retirement Savings, ECON. PoL'Y InST. (Dec. 10, 2019), https://www.epi.org/publication/the-state-of-american-retirement-savings [https://perma.cc/BZL5-CRJ7] (noting that the majority of Black and Hispanic families have no retirement savings).

340. See Gelter, supra note 88, at 949 (discussing the political preferences for shareholder primacy of U.S. voters).

341. See generally Leo E. Strine, Jr., Toward Common Sense and Common Ground? Reflections on the Shared Interests of Managers and Labor in a More Rational System of Corporate Governance, 33 J. CORP. L. 1, 4 (2007) (describing beneficiaries of retirement plans as "forced capitalists"); Gelter, supra note 88, at 936-46 (discussing the tradeoff between workers' interest qua workers and as investors saving for retirement).

342. On the history of German codetermination, see Pistor, supra note 93, at 165-77.

343. Supra notes 226-229 and accompanying text.

344. E.g., John T. Addison \& Claus Schnabel, Worker Directors: A German Product That Did Not Export?, 50 INDUS. REL. 354, 359 (2011) (discussing rent-seeking by labor as a motivation for codetermination).

345. The threshold amounts were initially higher but reduced to the current amounts in 2015. See Code de commerce [C. com.] [Commercial Code] art. L225-27-1. For a recent overview of employee representation requirements, see Michael Gold \& Jeremy Waddington, Introduction: Board-Level Employee Representation in Europe: State of Play, 25 EUR. J. INDUS. REL. 205 (2019); Christophe Clerc, La codétermination: un modèle européen? [Co-Determination : A European Model?], 130 REVUE D'ECONOMIE FINANCIERE 181, 186-88 (2018); 
employee representation has become part of the political debate. In the United Kingdom, Prime Minister Theresa May brought up the idea after taking over leadership of the government after the 2016 Brexit vote. ${ }^{346}$ In the United States, Senator Elizabeth Warren put forward a bill in $2018,{ }^{347}$ and Bernard Sanders made it part of his presidential campaign platform. ${ }^{348}$ On the international scale, it has been pointed out that income inequality and employee codetermination are negatively correlated. ${ }^{349}$ Even if the U.K. and U.S. proposals have led to tangible political outcomes, dissatisfaction with economic inequality further fueled by COVID-19 will likely increase the pressure to change.

This is not to say that this will necessarily have either efficient or inefficient results. It is also not clear that such systems would actually result in less inequality in the United States, especially during times of financial constraints. As we already discussed, it seems more plausible that they will create two classes of workers- "ins" and "outs"- where only the former hold jobs that give them some influence on the corporate level. ${ }^{350}$ This is true particularly in times of digitally-induced disruption of many industries. In any event, the key point here is that we are more likely to see it in terms of the political economy of corporate governance. The reason is going to be its effects on the public perception ("we are doing something for the middle class") rather than its actual benefits.

An even more difficult question is whether corporate law and governance can be used to address inequality in the more traditional sense, i.e., the growing gap between the rich and the poor, and economic pressures on the middle class. Many corporate law analysts believe that the recent switch toward "stakeholder governance" in the Business Roundtable statement is intended mainly to serve the interest of management by insulating it from shareholder pressure. ${ }^{351}$ In this view, if corporate law wholly absorbed this vision, it is unlikely that employees would benefit. The classic invective against stakeholder orientation is that managers will be less accountable because they will have a higher degree of discretion compared to a situation where they are required to maximize shareholder

Aline Conchon, Board-Level Representation in France: Employee Representatives' Counter-Strategies in Powerless Boards, in EUROPEAN BOARD-LEVEL EMPLOYEE REPRESENTATION: NATIONAL VARIATIONS IN INFLUENCE AND POWER 51, 54-55 (Jeremy Waddington ed., 2018); Dammann \& Eidenmüller, supra note 229, at 9-11; Udo Rehfeldt, Board-Level Employee Representation in France: Recent Developments and Debates, MitBestimMUNGSREPORT, No. 53e (2019), at 5.

346. Green PaPer, Dep'T. For Bus., Energy \& Indus. Strategy, Corporate Governance Reform 40 (2016); Nils Pratley, Theresa May's Plan to Put Workers in Boardrooms Is Extraordinary, GUARDIAN (July 11, 2016, 11:47 AM), https://www.theguardian.com/politics/nils-pratley-on-finance/2016/jul/11/theresa-mayplan-workers-boardroom-reform-extraordinary-tories [https://perma.cc/XK7N-YUK6].

347. Accountable Capitalism Act, S. 3348, 115th Cong. $\$ 6$ (2018) (proposing to require large firms to obtain federal incorporation, which would come with employee representation on the board).

348. Corporate Accountability and Democracy, BERNIE, https://berniesanders.com/issues/corporate-accountability-and-democracy [https://perma.cc/TPL9-B95R]; see, e.g., Gregory Krieg \& Ryan Nobles, Bernie Sanders Wants to Give Workers an Ownership Stakes in Big Companies, CNN: Politics (Oct. 14, 2019, 6:00 AM), $\quad$ https://www.cnn.com/2019/10/14/politics/bernie-sanders-worker-ownership-plan/index.html [https://perma.cc/R5XU-MDMJ].

349. April Hall, Employee as Director, DIRS. \& BDS. 40, 42 (2019) (graphically showing a negative correlation between stronger forms of employee representation and the Gini coefficient). However, one could argue that there may be other factors that likely explain both variables (endogeneity).

350. Supra Section IV.A.3.ii.

351. E.g., Bebchuk \& Tallarita, supra note 329, at 54. 
wealth. ${ }^{352}$ Managers and boards are likely to follow the money and maximize those interests from which they benefit most. Executive compensation-which is oriented toward stock price - will continue to play a role, as will the managerial labor market and the market for corporate control. ${ }^{353}$

International experience supports the concern that a mere shift in what the law states to be the "corporate purpose" or "corporate objective" will change little. For example, U.K. law today follows an "enlightened shareholder primacy" vision since the Companies Act 2006. ${ }^{354}$ Thus, while a director "must act in the way [s] he considers, in good faith, would be most likely to promote the success of the company for the benefit of its members as a whole," they must have regard to the interests of employees and certain other stakeholders in this context. ${ }^{355}$ While under this statute stakeholder interests are only instrumental for shareholder interests, this was not as unequivocal between 1980 and 2006 when the law required managers "to have regard to the interest of employees" without clarifying that shareholder interests were supreme. ${ }^{356}$ The provision was widely acknowledged to be irrelevant because employees were not given tools to enforce it, ${ }^{357}$ while U.K. takeover law set strong incentives in favor of management. ${ }^{358}$

Similarly, the current Indian law requires firms to pursue the interests of stakeholders $^{359}$ and is subject to a similar criticism because there is no effective enforcement mechanism. ${ }^{360}$ Continental European countries, such as Germany, France, and Italy, have long had debates - which were to some extent reflected in the case law - about whether directors and managers should have an obligation to pursue the "interests of shareholders" or pursue a "pluralist" corporate objective that would incorporate a larger set of stakeholders into the "interests of the enterprise" or "interest of the association." 361 All of these suffer

352. A.A. Berle Jr., For Whom Are Managers Trustees, 45 HARV L. REV. 1365, 1367 (1931) ("When the fiduciary obligation of the corporate management and 'control' to stockholders is weakened or eliminated, the management and 'control' become for all practical purposes absolute.").

353. Bebchuk \& Tallarita, supra note 329 , at 35-41.

354. Companies Act 2006, c. 46 (U.K.), § 172, https://www.legislation.gov.uk/ukpga/2006/46/contents [https://perma.cc/Q6JG-AWPL].

355. Id.

356. Companies Act 1980, § 46; Companies Act 1985, § 309(1) (“The matters to which the directors of a company are to have regard in the performance of their functions include the interests of the company's employees in general, as well as the interests of its members.").

357. E.g., D.D. Prentice, A Company and Its Employees: The Companies Act 1980, 10 InDus. L.J. 1, 4-5 (1981); Simon Deakin \& Giles Slinger, Hostile Takeovers, Corporate Law, and the Theory of the Firm, 24 J.L. \& Soc. 124, 135 (1997); Christopher M. Bruner, Power and Purpose in the "Anglo-American" Corporation, 50 VA. J. INT'L L. 579, 608 n.42 (2010).

358. Deakin \& Slinger, supra note 357 , at $135-36$.

359. The Companies Act, 2013, § 166(2) (India) (“A director of a company shall act in good faith in order to promote the objects of the company for the benefit of its members as a whole, and in the best interests of the company, its employees, the shareholders, the community and for the protection of environment.").

360. Mihir Naniwadekar \& Umakanth Varottil, The Stakeholder Approach Towards Directors' Duties Under Indian Company Law: A Comparative Analysis 13-18 (NUS, Working Paper 2016/006, 2018), http://ssrn.com/abstract=2822109 [https://perma.cc/Z7LR-Z4UL].

361. For Germany, see, e.g., Thomas Raiser, The Theory of Enterprise Law in the Federal Republic of Germany, 36 AM. J. COMPAR. L. 111, 123-24 (1988); Ingo Saenger, Conflicts of Interest of Supervisory Board Members in a German Stock Corporation and the Demand for Their Independence, 1 CORP. GOVERNANCE L. REV. 
from the same challenge, namely the difficulty of defining specific duties in the absence of a clear metric. ${ }^{362}$ France, since the 2019 PACTE law, explicitly states business associations are run in the company interest (intérêt social), taking into account the social and environmental aspects of its activities. ${ }^{363}$ Not unexpectedly, the revised section is subject to the same criticisms. ${ }^{364}$

Other legal instruments that shift bargaining power to labor, such as German codetermination or labor codes that empower unions more than in the United States, are typically much more significant. Disclosure requirements seem to have a greater impact in practice. For example, the U.K. Companies Act of 2006 bundled its "enlightened shareholder primacy principle" with a requirement to disclose the firm's activities across environmental, employment, social, community, and human rights issues. ${ }^{365}$ Similarly, the EU Accounting Directive now includes a requirement for non-financial disclosures relating to "environmental, social and employee matters, respect for human rights, anti-corruption and bribery matters. ${ }^{366}$ With a legal compliance requirement such as these, publicly traded corporations and their legal counsel are becoming more attentive to corporate social responsibility issues. Overall, however, it is not a wild guess to say that firms will continue to experience pressure to foster the interests of a wide set of stakeholders. As Gatti and Ondersma have recently pointed out, in the United States that would likely gain political capital in the

147, 154-55 (2005); Jean du Plessis, Key Corporate Governance Themes and Issues in a Globalised and Internationalised World, 26 EuR. Bus. L. Rev. 1, 4 (2015); Ingo Saenger, Best Interests of the Corporation, Procedural Questions of Enforcing Individual and Corporate Rights and Legal Actions Against Board Members, 26 EuR. Bus. L. REV. 13, 14 (2015); for France, Jean Paillusseau, The Nature of the Company, in EuROPEAN Company Laws. A Comparative ApProach 19, 21-26 (Robert R. Drury \& Peter G. Xuereb eds., 1991); Veronique Magnier, Makeup of Boards: A New Corporate Paradigm, for Which Governance, 2019 EuR. Bus. L. REv. 237, 250-51; for Italy, Monica Cossu, The "Company's Interest" of the "Società Aperte" Under Italian Corporate Laws, 2013 EUR. Co. \& FIN. L. REV. 45. For a historical overview of Germany and France, see Martin Gelter, Taming or Protecting the Modern Corporation? Shareholder/Stakeholder Debates in a Comparative Light, 7 N.Y.U. J.L. \& Bus. 641, 678-718 (2011); Martin Gelter, From Institutional Theories to Private Pensions, Fordham L. Legal Stud. Rsch. Paper No. 2463275, at 4-7 (2014), https://ssrn.com/abstract=2463275 [https://perma.cc/6LGH-47GU].

362. E.g., J.J. du Plessis, Corporate Governance: Reflections on the German Two-Tier Board System, 1996 J. S. AFRICAN L. 20, 32-33 (noting that supervisory board members' duties become unmanageable when defined in terms of the interest of the corporation); Alexander Schall et al., Promoting an Inclusive Approach on the Part of Directors: The UK and German Positions, 6 J. CORP. L. STUD. 299, 308-09 (2006).

363. CoDE CIVIL [C. civ.] [Civil Code] (Fr.), as amended by Loi no 2019-486 du 22 mai 2019 relative à la croissance et la transformation des entreprises.

364. See, e.g., Morgane Tirel, La réforme de l'intérêt social et la " ponctuation signifiante » [The Reform of the Social Interest and "Significant Punctuation"], 2019 RECUEIL DALLOZ 2317 (surveying the debate following the enactment of law).

365. Companies Act 2006, c. 46 (U.K.), $\S 417(5)$. Since 2013, the same disclosures must be made in the company's strategic report. See id. at $\$ 414 \mathrm{C}(7)(\mathrm{b})$. In addition, British companies must make disclosures about greenhouse gas emissions under Schedule 15 to the Companies Act. See Companies Act 2006 (U.K.) (Strategic Report and Directors' Report) Regulations 2013, SI 2013/1970 (amending the Companies Act 2006 and, among other things, eliminating s. 417).

366. EU Accounting Directive 2014/95/EU, 2014 O.J. (L 330) 1, as amended by Directive 2014/102/EU, 2014 O.J. (L 334) 86, art. 19a, 29a. See, e.g., Enriques et al., supra note 100, at 95 (suggesting that pressure from shareholders will compel corporations to be more compliant with ESG demands). 
process. ${ }^{367}$ It is less clear whether and how much workers or other stakeholders will benefit.

Besides the traditional struggle between "capital" and the working middle classes, public debates are increasingly concerned about different forms of inequality, namely between genders as well as ethnic groups. In its entirety, the coronavirus crisis as an accelerator of trends and driver of inequality will likely bring long-term effects on social attention to ethnic minority groups. ${ }^{368}$ At least in the United States, but potentially also in some other jurisdictions, these social developments will also rub off on corporate goals and general social values. Nowadays, entrepreneurial culture sees an increase in stakeholder focus on resolving economic inequalities. A call for alignment of entrepreneurial activities with the pursuit of social justice and the achievement of climate change goals is particularly widespread in public protests and online discussions.

Contemporary social media plays a unique and unprecedented role as an instant accelerator of trends that are easily accessible and can be followed by all social groups. Social media online forums encourage transparency and perpetuate group dynamics that can quickly ignite and evoke general trends around the world. These trends are now putting enormous pressure on companies, public institutions, as well as individuals and politicians. Corporations are sometimes seen as quasi-political institutions. Together with public institutions, the corporate world is also devoted to higher social goals - such as democracy, social equality, and environmental coordination. ${ }^{369}$ Entrepreneurs and politicians are increasingly under pressure to consider these diverse tendencies with their actions and measures. It is conceivable for entrepreneurial disruptions to arise, in which pressure from competitive markets and critical political levels will turn the ability to react flexibly and sensitively to different trends in society into a competitive advantage. ${ }^{370}$ Those firms that can act quickly and flexibly with empathy for others and sensitivity for crowds but also skills to use information and online communication wisely may then be more likely to survive.

During the past decade, a more tangible force for change on social issues has emerged in the form of the use of shareholder power to improve corporate social responsibility (CSR), which can be defined as the inclusion of environmental, social, and governance issues (ESG) into corporate decision-making. ${ }^{371}$ In some cases, policymakers attempted to

367. Matteo Gatti \& Chrystin Ondersma, Can a Broader Corporate Purpose Redress Inequality? The Stakeholder Approach Chimera, 46 J. CORP. L. 1, 60 (2020).

368. See, e.g., Paine, supra note 175 ("The pandemic's disparate effects and ensuing national outcry over racial inequity have put a spotlight on board composition, especially as it relates to directors' race and ethnicity.").

369. E.g., Boeing CEO Pledges a 20 Percent Increase in Black Employees, N.Y. Post (Aug. 28, 2020), https://nypost.com/2020/08/28/boeing-ceo-eyes-20-percent-increase-in-black-employees [https://perma.cc/8E4E-NF6K].

370. See Kosmas Papadopoulos et al., ESG Drivers and the COVID-19 Catalyst, HARV. L. SCH. F. ON CoRP. GOVERNANCE (Dec. 27, 2020), https://corpgov.law.harvard.edu/2020/12/27/esg-drivers-and-the-covid-19-catalyst [https://perma.cc/NV95-F375] (noting the increasing public pressure on firms to pursue ESG issues).

371. Hao Liang \& Luc Renneboog, Corporate Social Responsibility and Sustainable Finance: A Review of the Literature 2 (Eur. Corp. Governance Inst.-Fin., Working Paper No. 701/2020, 2020), https://ssrn.com/abstract=3698631 [https://perma.cc/6QJU-H5Z8]. 
use increased shareholder powers-especially regarding runaway executive compensation - partly to reduce inequality. ${ }^{372}$ The larger social effects of such instruments are limited in that they do not reduce economic inequality between workers with well-paying corporate jobs and those who do not. This tends to match the distinction between those with and without significant savings invested in the stock market. In recent years, the use of shareholder powers for social purposes is closely linked to the activities of institutional investors, most of all the "Big 3" fund management advisors (BlackRock, Vanguard, and State Street) to use their influence for social change. ${ }^{373}$ One area is gender diversity on the board, where the Big 3 have pushed for increased female representation on the board during the past years. ${ }^{374}$ BlackRock has recently affirmed its commitment to stakeholders affected by COVID-19 as well as racial equity and environmental justice. ${ }^{375}$ Environmental issues and climate change, which we discuss below, have been a particular focus of institutional activism.

\section{Climate Change, Institutional Shareholder Stewardship, and Other Public Policy Goals}

The second trend that has had a widespread impact on the corporate world in recent years is attention to climate change. Global warming accounts for one of the most pressing contemporary problems of humankind as for exacerbating more complex and unprecedented environmental risks than ever before. ${ }^{376}$ As never before in history since the birth of the earth and modern productivity, environmental sensitivity to economic growth and corporate activities challenge modern democracy and economic development. ${ }^{377}$

There are top-down approaches to combating the climate crisis. For instance, the United Nations Environment Programme (UNEP) advocates for economic growth within the framework of sustainability. The Intergovernmental Panel on Climate Change (IPCC) research and United Nations Conferences of the Parties (COP) have generated substantive

372. Supra notes 132-134 and accompanying text. See also Mariana Pargendler, The Corporate Governance Obsession, 42 J. CORP. L. 359, 391-92 (2016) (regarding "say on pay" as an instrument intended to reduce inequality). The link between executive compensation and inequality is maybe most evident with "pay ratio" disclosure requirements. See, e.g., Dodd-Frank Wall Street Reform and Consumer Protection Act § 953, Pub. L. No. 111-203, § 953, 124 Stat. 1376 (mandating the pay ratio disclosure).

373. See, e.g., Giovanni Strampelli, Can BlackRock Save the Planet? The Institutional Investors' Role in Stakeholder Capitalism, 11 HARV. BUS. L. REV. (forthcoming 2021) (manuscript at 5-6) (https://ssrn.com/abstract=3718255 [https://perma.cc/GBC8-3BYH]) (quoting statements by Larry Fink, CEO of BlackRock).

374. E.g., Todd A. Gormley et al., The Big Three and Board Gender Diversity: The Effectiveness of Shareholder Voice (Eur. Corp. Governance Inst.-Fin., Working Paper No. 714/2020, 2020), https://ssrn.com/abstract=3724653 [https://perma.cc/7MRD-C7MQ].

375. BlackRock Investment Stewardship: 2020 Q2 Global Quarterly Stewardship Report, BLACKROCK 3 (July 5, 2020), https://www.blackrock.com/corporate/literature/publication/blk-qrtly-stewardship-report-q22020.pdf [https://perma.cc/3469-QZN2]; see also Bernard S. Sharfman, The Conflict Between Blackrock's Shareholder Activism and ERISA's Fiduciary Duties, CASE W. RSRV. L. REV. (forthcoming 2021) (manuscript at 8), https://ssrn.com/abstract=3691957 [https://perma.cc/DWL5-BMTR] (analyzing Blackrock's commitment).

376. See generally Julia M. Puaschunder, On the Social Representations of Intergenerational Equity, 4 OXFORD J. FIN. \& RISK PERSP. 78 (2015) (discussing intergenerational climate change complexities).

377. Miguel Angel Centeno \& Alex Tham, Conference on Emergent Risk, (Sept. 2012), https://scholar.princeton.edu/emergentrisk/home; Global Competitiveness Report 2015, WORLD ECON. F. (Sept. 22, 2015), https://www.weforum.org/reports/global-competitiveness-report-2015 [https://perma.cc/9H27-57PL]. 
literature on global climate change negotiations that stresses the currently most urgent need for climate change mitigation and adaptation around the world. Since 2015, the Sustainable Development Goals encouraged countries to create jobs in green industries in order to boost the world economy and curb climate change at the same time. ${ }^{378}$ In 2019 , over 600 corporations signed a letter to the United States Congress advocating for the reduction of greenhouse gas emissions in support of climate attention. ${ }^{379}$ The signing entities pledged to move away from fossil fuel extraction and subsidies in order to transition to renewable energy, expand public transport, and reduce overall emissions.

Since 2019, Senator Edward Markey and Representative Alexandria Ocasio-Cortez have advocated for the United States to transition to the exclusive use of renewable energy and new transportation technologies such as electric cars and high-speed rail systems as an extension of Obama administration plans. ${ }^{380}$ The so-called Green New Deal (GND) aims at lifting up vulnerable communities via state-sponsored employment, universal health care, increased minimum wages, and preventing monopolies. The historical New Deal was a bonds financing strategy of the Roosevelt administration in the United States between 1932 and $1939 .{ }^{381}$ In total, around fifteen to thirty-five billion USD were spent on a series of development programs that funded public work projects, financial reform, and regulation efforts on economic development. ${ }^{382}$ The idea of a GND now captures a ten-year national mobilization via work security and working conditions by high-quality health care, affordable housing, economic security, access to clean water, air, healthy food and nature, education, clean, renewable, zero-emission energy, repairing of infrastructure, energy efficient smart power grids, upgraded living conditions, pollution elimination, clean manufacturing, and positive work collaborations.

The Biden-Harris Administration promoted an economic transition in line with sustainability goals throughout their election campaign. ${ }^{383}$ The proposed GND economic plan advocates using a carbon tax and green bonds in order to stimulate economic growth. Based on the foundations of Modern Monetary Theory, the GND aims to vitalize the economy through a transition to renewable energy and sustainable growth. ${ }^{384}$ The GND serves as a

378. Edward Barbier, A Global Green New Deal, Report Prepared for the Green Economy Initiative of UNEP., 2009, UNITED NATIONS ENV'T, https://sustainabledevelopment.un.org/index.php?page=view \&type $=400 \& n r=670 \& m e n u=1515 \quad$ [https://perma.cc/HS54-PWZ2]; see also Mariana Pargendler, The Rise of International Corporate Law 24-32 (Eur. Corp. Governance Inst. L. Working Paper No. 555/2020, 2020), https://ssrn.com/abstract=3728650 [https://perma.cc/SSM4-MZBF] (providing a historical overview of UN initiatives relating to ESG, particularly climate change).

379. Group Letter to Congress Urging Green New Deal Passage, EARTHwORKs, https://www.earthworks.org/publications/group-letter-to-congress-urging-green-new-deal-passage/ (last visited Jan. 11, 2021).

380. H.R. Res. 109, 116th Cong. (2019) (as introduced, Feb. 7, 2019).

381. Julia M. Puaschunder, The Green New Deal: Historical Foundations, Economic Fundamentals and Implementation Strategies, FinReg Blog, Glob. Fin. MKts. CtR., Duke Univ. Sch. L. (Oct. 30, 2020), https://sites.law.duke.edu/thefinregblog/2020/10/30/the-green-new-deal-historical-foundations-economic-fundamentals-and-implementation-strategies/ [https://perma.cc/66MU-N5U7].

382. Id.

383. Joseph Biden, The Biden Plan for a Clean Energy Revolution and Environmental Justice, https://joebiden.com/climate-plan/ [https://perma.cc/TTC5-5GFF].

384. Economic theories that support the arguments advanced by the GND include John Maynard Keynes' spending multiplier effect (1936), which captures the ratio of a change in national income to any autonomous 
market solution to implement global environmental governance as "the sum of the many ways individuals and institutions, public and private, manage their common affairs." 385 The GND thereby combines former U.S. President Roosevelt's economic approach with modern ideas such as renewable energy and resource efficiency. Various proposals for a GND have been made internationally, for instance in Australia, Canada, and Europe. Since 2019, the European Green Deal (EGD) has been promoted by the European Commission. ${ }^{386}$

Whether and how these Green Deals will be implemented is yet to be determined. Policymakers will likely use different instruments, including Global Environmental Governance (such as formal legal treaties, global conferences but also intergovernmental panels), ${ }^{387}$ fiscal space (creating revenues via carbon tax), ${ }^{388}$ monetary and credit policies (including insurances) ${ }^{389}$ central bank bonds and climate stabilization financialization, ${ }^{390}$ emissions trading, ${ }^{391}$ green bonds, ${ }^{392}$ environmental pricing reform, ${ }^{393}$ absorbing $\mathrm{CO}_{2}$ and

change in spending — such as private investment spending, consumer spending, government spending, or spending by foreigners on the country's exports that causes it. E.g., JOHN MAYNARD KeYNES, THE GENERAL THEORY OF EMPLOYMENT, INTEREST AND MONEY (1936).

385. Julia Margarete Puaschunder, The Green New Deal: Historical Foundations, Economic Fundamentals and Implementation Strategies 41(2020) (unpublished manuscript) (on file with author).

386. See A European Green Deal, EuR. COMM'N, https://ec.europa.eu/info/strategy/priorities-20192024/european-green-deal_en [https://perma.cc/FT85-GC9Z].

387. See, e.g., Julia Margarete Puaschunder, Governance and Climate Justice: Global South AND DEVELOPING NATIONS (2020).

388. Jeffrey D. Sachs, Climate Change and Intergenerational Well-Being, in THE OXFORD HANDBOOK OF THE MACROECONOMics OF GlOBAL WARMing 248 (Lucas Bernard \& Willi Semmler eds., 2015); Sergey Orlov et al., Green Bonds, Transition to a Low-Carbon Economy, and Intergenerational Fairness: Evidence from an Extended DICE Model (2018) (unpublished manuscript) (on file with author); Julia Margarete Puaschunder, Future Climate Wealth of Nations' Winners and Losers (2019) (unpublished manuscript) (on file with author); João Paulo Braga \& Willi Semmler, Ökonomie und Klimapolitik: So könnte es gehen, DIE ZEIT (Mar. 5, 2020), https://www.zeit.de/autoren/B/Joao-Paulo_Braga/ [https://perma.cc/GMG3-BQM].

389. William D. Nordhaus, Climate Change: The Ultimate Challenge for Economics, NoBel Prize COMM., https://ideas.repec.org/p/ris/nobelp/2018_003.html [https://perma.cc/2CUR-BK2H].

390. Emanuele Campiglio et al., Climate Change Challenges for Central Banks and Financial Regulators, 8 NATURe Climate Change 462 (2018).

391. Emissions trading currently covers around $20 \%$ of all global $\mathrm{CO}_{2}$ emissions in about forty countries of the world and over twenty cities, municipalities and provinces of the world ranging from China to the EU. Pricing Carbon, WORLD BANK, https://www.worldbank.org/en/programs/pricing-carbon [https://perma.cc/HB2ZV7AQ].

392. These could be used for investments in clean energy innovations such as solar power and wind turbines, eco-friendly infrastructure, and more research and development in clean energy and green technology. MARIANA Mazzucato, The Entrepreneurial State: Debunking Public vs. Private Sector Myths (2015); Afsaneh Beschloss \& Mina Mashayekhi, A Greener Future for Finance, 56 FIN. DEv. 1, 60 (2019); The Impact of Investing, NYC MUN. WATER FIN. AUTH., https://www1.nyc.gov/site/nyw/investing-in-nyw-bonds/the-impact-of-investing.page [https://perma.cc/UR8A-LAAF].

393. Environmental pricing reform aims at adjusting market prices to include negative externality costs and risks in market pricing. 
forestation, ${ }^{394}$ behavioral changes, ${ }^{395}$ sustainable tourism that mitigates the negative impact on the environment and society, as well as engaging financial markets and portfolio managers.

Bottom-up efforts to face the climate challenge have changed as well since the novel coronavirus crisis has started. The COVID-19 lockdowns have fueled widespread anger, with social masses protesting physically and online around the world. This has further increased pressure on corporations to adopt socially conscientious goals, among which care for climate justice is one of the most blatantly argued. Protestors have called on corporate boards to make economic sacrifices today for future generations by shifting corporate conduct to a more environmentally-friendly way and cutting on carbon emissions to avert global warming. ${ }^{396}$ While climate change mitigation will likely come at the expense of a transition period to clean energy, many scientists argue that it is justified given a shrinking time window prior to reaching tipping points that lock the world in a trajectory of changing temperature irreversibly. ${ }^{397}$ Sustainable financing strategies to fund climate stabilizing policies and pro-environmental action are at present currently being developed.

In recent decades, environmentalism has already become a subject of corporate endeavors openly intended to serve the community. ${ }^{398}$ In addition, firms have increasingly begun to cater to shareholder interests professing to aim at long-term stability and widespread societal acceptance of pro-social corporate governance. First, CSR codes of conduct integrated social responsibility practices into what was considered to be state-of-the-art financial investment practices. ${ }^{399}$ The finance community concurrently started paying attention to ethical considerations of the asset-issuing entities. ${ }^{400}$ Empirical research found that corporate social engagement was associated with corporate financial performance and positively related to long-term investments via litigation risk minimization, branding, and widespread community support. ${ }^{401}$

394. Market innovations include decentralized energy grids that are run on blockchain approaches, green rooftops in cities, carbon-negative fungus-based clothing, as well as industrial-scale carbon capture by machinery and windmills.

395. Behavioral tools include "nudges" and "winks" towards environmentally and intergenerationally conscientiousness as easily implementable sources to educate and change people's behavior without direct enforcement. Julia PuAschunder, Behavioral ECONOMics and FinANCE LEADERShIP: Nudging AND WinKING to MAKe BetTER CHOICES (2020).

396. Sachs, supra note 388, at 248.

397. Michael Oppenheimer et al., Climate Change: The Limits of Consensus, 317 SCIENCE 1505 (2007)

398. Julia M. Puaschunder, Intergenerational Climate Change Burden Sharing: An Economics of Climate Stability Research Agenda Proposal, 16 Global J. MGMt. \& Bus. Res. 30 (2016).

399. Catherine C. Langlois \& Bodo B. Schlegelmilch, Do Corporate Codes of Ethics Reflect National Character? Evidence from Europe and the United States, 21 J. INT'L BUS. STUD. 519, 519 (1990); Abagail McWilliams \& Donald Siegel, Corporate Social Responsibility and Financial Performance: Correlation or Mis-Specification?, 21 StRategic MGMT. J. 603, 603 (2000).

400. Julia M. Puaschunder, Ethical and Socially Responsible Investing, in INVESTOR BEHAVIOR 415, $417-$ 20 (H. Kent Baker \& Victor Ricciardi eds., 2014); Shipeng Yan et al., The Rise of Socially Responsible Investment Funds: The Paradoxical Role of the Financial Logic, 64 ADMIN. SCI. Q. 466 (2019); see generally Ken LiTTLE, SOCIALly ResPonsible InVESTING: PUT YOUR MONEY WHERE Your VALUES ARE (2008).

401. See generally Tae Hee Choi \& Jinchul Jung, Ethical Commitment, Financial Performance, and Valuation: An Empirical Investigation of Korean Companies, 81 J. Bus. ETHICs 447 (2008); Sandra A. Waddock \& Samuel B. Graves, The Corporate Social Performance-Financial Performance Link, 18 STRAT. MgMT. J. 303 (1997) (all showing the link between the two). 
The financial social responsibility movement foremost came to life in Socially Responsible Investments (SRI), which integrate social, ethical, and environmental concerns into portfolio choices and financial management. SRIs are based on socio-psychological motives of ethical investment. ${ }^{402}$ Thereby conscientious investors pursue economic and social value maximization alike in social screenings, shareholder advocacy, and community investing. ${ }^{403}$ Socially conscientious market choices are based on positive and negative screenings, including economic fundamentals as well as qualitative intra- (e.g., corporate policies and practices, employee relations) and extra-organizational (e.g., externalities on current and future constituents) corporate social conduct. ${ }^{404}$ Positive screenings favor corporations with sound social and environmental records that pay attention to human rights and labor standards, equal opportunities, environmental protection, consumer safety, community concerns, and stakeholder relations. Negative screenings exclude corporations that contribute to socially irresponsible activities such as addictive products and services (e.g., liquor, tobacco, gambling), defense (e.g., weapons, firearms, landmines), environmentally hazardous production (e.g., pollution, nuclear power) and humanitarian deficiencies (e.g., discrimination, human rights violations) or activities labelled as "politically incorrect." Post-hoc negative screenings lead to the removal of investment capital from portfolios to attribute global governance goals. ${ }^{405}$ Political divestiture is a negative-screening-based strategy of removing stocks from a portfolio to screen out socially irresponsible corporations based on social, ethical and religious objections. ${ }^{406}$ Pressure of this type thereby induces shareholders to divest from certain markets with the goal of accomplishing sociopolitical change for political and social reasons. ${ }^{407}$ Socially responsible investors thus use their market power to put pressure on governments stirring war and social conflict, supporting terrorism and engaging in human rights violations. ${ }^{408}$

How COVID-19 will affect these trends of environmental concerns entering the corporate and finance world is not yet entirely clear. It is plausible that the pandemic will change the way individuals consume in line with a more environmentally conscientious lifestyle aiding sustainability. COVID-19 has triggered attention to a healthy and consumption-conscientious way of living. This also goes hand-in-hand with sustainability pledges as green food choices often meet the criteria of ecological and $\mathrm{CO}_{2}$-friendly production. COVID-19 increased the call for firms and institutional investors to pay attention to healthy

402. Julia Margarete Puaschunder, Socio-Psychological Motives of Socially Responsible Investors, 19 GLOB. CORP. GOVERNANCE 209 (2017).

403. Craig Mackenzie \& Alan Lewis, Morals and Markets: The Case of Ethical Investing, 9 Bus. ETHICS Q. 439 (1999); Puaschunder, supra note 402.

404. Steve Schueth, Socially Responsible Investing in the United States, 43 J. Bus. ETHICs 189 (2003).

405. Dominic Broadhurst et al., Ethical and Socially Responsible InVEStMent: A Reference GUIDE FOR RESEARCHERS (2003).

406. McWilliams \& Siegel, supra note 399.

407. Julia M. Puaschunder, The Role of Political Divestiture for Sustainable Development, 6 J. MGMT. \& SUSTAINABILITY 76 (2016).

408. Julia M. Puaschunder, Socially Responsible Investment as Emergent Risk Prevention and Means to Imbue Trust in the Post-2008/2009 World Financial Crisis Economy, in ROUTLEDGE HANDBOOK OF SOCIAL AND SuSTAINABLE FinANCE 222 (Othmar Lehner ed., 2016); Martha A. Starr, Socially Responsible Investment and Pro-Social Change, 42 J. ECON. IsSUES 51(2008). 
lifestyles that foster prevention and help reduce the spread of the pandemic. ${ }^{409}$ Corporations may also have to give in to stakeholder pressures advocating for corporations to serve the greater good and wider stakeholder community. SRI and carbon divestiture are effective corporate strategies against the backdrop of a warming globe. Corporations that opt for early withdrawal may enjoy a first-mover advantage that also signals proactive ethical leadership in an already ongoing transition to renewable energy. In addition, such firms may qualify to issue climate bonds, thus reducing firms' costs of capital allowing them to use SRI as a strategic, entrepreneurial move. ${ }^{410}$ Further, corporations remaining in carbonintensive unstable markets may suffer long-term losses in the wake of an overall economic market decline in carbon industries and may be exposed to future litigation risks for environmental damages that could be avoided by fossil fuel divestiture.

After COVID-19, additional organized pressure on corporations to move against climate change is likely to come from two sources, namely governments and institutional investors. First, in the wake of the crisis, the economy in many capitalist countries has become more governmentally planned during the epidemic. Governments around the globe have ordered the shutdown of some industries and have directed others to mass-produce urgently needed supplies such as masks or ventilators. There are often good reasons to deviate from a pure market economy in situations of severe crisis. Market disruptions (such as wars or other severe demand shocks) often lead to market failures where vigorous competition leads to social harm because key products and services are in short supply, thus prompting the government to step in to coordinate distribution. ${ }^{411}$ The pandemic has led to political pressure, but also pressure from groups such as customers, investors, and employees fueled by the lockdowns has intensified already-existing trends pushing corporations toward aiding with the resolution of global problems that do not necessarily improve corporate profits. Joining the chorus, institutional investors, possibly seeking to address portfolio-wide risks, called upon pharmaceutical firms to cooperate to develop novel antiviral treatments and vaccines. ${ }^{412}$ It is not entirely clear that these firms or their investors will greatly profit from such treatments, which will have to be mass-produced and delivered

409. Supra Section IV.A.3.

410. Julia M. Puaschunder, When Investors Care About Politics: A Meta-Synthesis of Political Divestiture Studies on the Capital Flight from South Africa During Apartheid, 5 Bus. PEACE \& SuSTAINABLE Dev. 29 (2015).

411. Barak Orbach, Antitrust in the Shadow of Market Disruptions, 34 ANTITRUST 32 (2020).

412. Lev Facher, NIH Partners with 16 Drug Companies in Hopes of Accelerating COVID-19 Treatments and Vaccines, STAT (Apr. 17, 2020), https://www.statnews.com/2020/04/17/nih-partners-with-16-drug-companies-in-hopes-of-accelerating-covid-19-treatments-and-vaccines/ [https://perma.cc/XU4C-LH5M]; Attracta Mooney \& Donato Paolo Mancini, Drugmakers Urged to Collaborate on Coronavirus Vaccine, Fin. TIMES (Apr. 23, 2020), https://www.ft.com/content/b452ceb9-765a-4c25-9876-fb73d736f92a [https://perma.cc/7MK58M8H]; Leah Rosenbaum, New Pharma Company Lands \$354 Million Government Contract to Produce Coronavirus Drugs in the U.S., FORBES (May 19, 2020), https://www.forbes.com/sites/leahrosenbaum/2020/05/18/new-pharma-company-lands-354-million-government-contract-to-produce-coronavirusdrugs-in-the-us [https://perma.cc/5X9X-GZ2Q]; Leandra Bernstein, Pharmaceutical Companies Tell Congress They Expect Coronavirus Vaccine Profits, WJLA (July 21, 2020), https://wjla.com/news/nation-world/pharmaceutical-companies-tell-congress-they-expect-coronavirus-vaccine-profits [https://perma.cc/TSK4-CP58]; HHS, DOD Collaborate with Johnson \& Johnson to Produce Millions of COVID-19 Investigational Vaccine Doses, U.S. DEP'T OF HEALTH \& HuM. SERvs. (Aug. 5, 2020), https://www.hhs.gov/about/news/2020/08/05/hhs-dodcollaborate-with-johnson-and-johnson-to-produce-millions-of-covid-19-investigational-vaccine-doses.html. 
quickly to quell the disease. ${ }^{413}$ Nevertheless, competition authorities around the world agreed to suspend antitrust enforcement to allow necessary cooperation among competitors. ${ }^{414}$ In September 2020, leading pharmaceutical firms published a joint statement agreeing not to file for regulatory authorization of their products until safety has been proven, thus curbing competition among each other. ${ }^{415}$

Politicians will be tempted to retain this "war economy",416 to address other issues of the day, so they may also turn to regulating the corporate sector on climate change concerns. ${ }^{417}$ Governments may now be more attentive to stakeholder urges and investor responsibility when using their newfound position as crisis managers and financial aid planners with extended powers during states of healthcare emergencies and pandemic risks to remedy other social ills besides COVID-19, particularly climate change. ${ }^{418}$ Strengthened command-and-control powers after COVID-19 may persist beyond the virus crisis. While the economic fallout of the coronavirus crisis gets cured by iconic governmental rescue packages and bailouts, these extensive aids may be used to implement system change- see for instance the pledges of the forthcoming The World Economic Forum's "The Great Reset Program 2021.,419

413. See Matt Levine, Investors Feel Good About Covid Bonds, BloOMBERG Op. (May 15, 2020), https://www.bloomberg.com/opinion/articles/2020-05-15/investors-feel-good-about-covid-bonds [https://perma.cc/3K4K-9RTL] (suggesting that investors may benefit across their portfolios even if pharmaceutical firms do not profit).

414. Orbach, supra note 411, at 32; see also Joint Antitrust Statement Regarding COVID-19, U.S. DEP'T OF Just. (Mar. 2020), https://www.justice.gov/atr/joint-antitrust-statement-regarding-covid-19 [https://perma.cc/4YLU-HXNQ] (addressing the need for all levels of government to cooperate with private businesses to tackle COVID-19).

415. Biopharma Leaders Unite to Stand with Science, BusinessWIRE (Sept. 8, 2020, 6:30 AM), https://www.businesswire.com/news/home/20200908005282/en [https://perma.cc/97L7-KTY3]; see also Barak Orbach, On the COVID-19 Vaccine Corporate Pledge, HaRv. L. SCH. F. ON CoRP. Governance (Sept. 10, 2020), https://corpgov.law.harvard.edu/2020/09/10/on-the-covid-19-vaccine-corporate-pledge [https://perma.cc/Y2JN-9TM9] (noting the anticompetitive effects of the pledge).

416. John Cassidy, The Coronavirus Calls for Wartime Economic Thinking, NEW YoRKER (Mar. 16, 2020), https://www.newyorker.com/news/our-columnists/the-coronavirus-calls-for-wartime-economic-thinking; Daniel Susskind, The Pandemic's Economic Lessons, ATLANTIC (Apr. 6, 2020), https://www.theatlantic.com/international/archive/2020/04/lessons-wartime-economics-coronavirus-covid19/609439 [https://perma.cc/9NSRUZBE] (discussing the analogy to the war economy and the strong interference of the government with private contracts, e.g., with the U.K. government effectively "underwriting almost the entire private sector through wage guarantees"); Gary Pinkus \& Sree Ramaswamy, The 'War' on COVID-19: What Real Wars Do (and Don 't) Teach Us About the Economic Impact of the Pandemic, McKinseY \& Co. (May 14, 2020), https://www.mckinsey.com/business-functions/strategy-and-corporate-finance/our-insights/the-war-on-covid-19-what-real-warsdo-and-dont-teach-us-about-the-economic-impact-of-the-pandemic\# [https://perma.cc/9VAS-JREV].

417. For example, the 2008 Automobile Industry Bailout in the United States was followed by tighter rules on emissions and other environmentally oriented goals. Myanna Dellinger, Airline Bailouts and Climate Change Re-Regulation, 47 N. Ky. L. REv. 95, 102, 106-07 (2020).

418. E.g., Nicholas Mulder, The Coronavirus War Economy Will Change the World, FOREIGN POL'Y (Mar. 26, 2020), https://foreignpolicy.com/2020/03/26/the-coronavirus-war-economy-will-change-the-world [https://perma.cc/6V3K-2UAR] (speculating, among other things, that governments might use their emergency powers to combat climate change).

419. Adrian Monck, The Great Reset: A Unique Twin Summit to Begin 2021, World ECON. F. (June 3, 2020), https://www.weforum.org/press/2020/06/the-great-reset-a-unique-twin-summit-to-begin-2021 [https://perma.cc/XZZ8-KPC2]. 
The COVID-19 governmental shock therapy may also peg any governmental aid to conditionalities that may also allow governments to direct firms to address the climate change challenge. Governmental crisis management may also use its regrown authority and the corporate dependency on public emergency funds and rescue bail-out packages to set incentives to implement environmental degrowth as outlined in the Green New Deal (GND). ${ }^{420}$ Corporations dependent on governmental bailout plans and tax cuts may softly be forced to adopt and adapt to serving those who fund these rescue packages via their tax. As a positive market incentive plan, the government may thereby urge the industry to transition to a green economy or implement ideas brought forward in the wake of the GND. The GND serves as a market solution to implement global environmental and pro-social governance as "the sum of the many ways individuals and institutions, public and private, manage their common affairs." 421 Corporations that are dependent on governmental aid will likely be obliged to follow the guidelines of the GND and implement eco-friendly recovery solutions.

The second major source of pressure on corporations will be the finance sector. On a broader institutional level, already before COVID-19, institutional investors increasingly pushed firms toward more responsible environmental conduct. ${ }^{422} \mathrm{~A}$ recent political divestiture trend has been the disinvestment of fossil fuels to implement climate stabilization by shifting to renewable energy sources. Negative screening comes to life in fossil fuel divestments. Fossil fuel divestment pegged to investment in renewable energy is the removal of investment assets including stocks, bonds, and investment funds from companies involved in extracting fossil fuels, in an attempt to reduce climate change by tackling its ultimate causes. ${ }^{423}$ Numerous groups advocate fossil fuel divestment, which in 2015 was reportedly the fastest growing divestment movement in history. ${ }^{424}$ Beginning on campuses in the United States in 2010 with students urging their administrations to reallocate investments from the fossil fuel industry to clean energy and communities most impacted by climate change, the movement quickly spread across the globe. ${ }^{425}$ By December 2016, a total of 688 institutions and over 58,000 individuals representing $\$ 5.5$ trillion in assets worldwide had been divested to move away from fossil fuels-driven economic growth. ${ }^{426}$

The current COVID-19 crisis characterized by lockdowns and economic consumption crunches also bears an opportunity to divest not only on the individual but also on the

420. Supra text accompanying notes 380-384.

421. Thomas G. Weiss, Governance, Good Governance and Global Governance: Conceptual and Actual Challenges, 21 THIRD WORLD Q. 795, 796 (2020).

422. See generally Michal Barzuza et al., Shareholder Value(s): Index Fund ESG Activism and the New Millennial Corporate Governance, 93 S. CAL. L. REV. 101 (forthcoming 2021) (discussing how companies have begun to emphasize environmental responsibility).

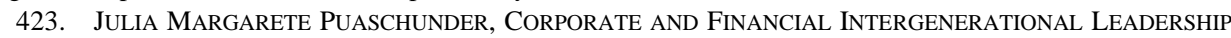
45 (2019).

424. Adam Vaughan, Fossil Fuel Divestment: A Brief History, GuARDIAN (Oct. 8, 2014, 11:24 AM), https://www.theguardian.com/environment/2014/oct/08/fossil-fuel-divestment-a-brief-history [https://perma.cc/ak8v-8rze].

425. PUASCHUNDER, supra note 423.

426. Damian Carrington, Fossil Fuel Divestment Funds Double to \$5TN in a Year, GUARDIAN (Dec. 12, 2016, 11:00 AM), https://www.theguardian.com/environment/2016/dec/12/fossil-fuel-divestment-funds-double5tn-in-a-year [https://perma.cc/5FLK-534S]. 
corporate and financial level in reassessing one's own personal consumption behavior, resetting corporate conduct with cleaner and more environmentally friendly means, and steering the finance world into a more sustainable digitalization economic growth focus. In terms of significance in the market, fossil fuel has lost ground to "digitalized" corporations that generate economic growth through the creation of online resources. ${ }^{427}$ This is increasingly reflected in the S\&P 500 and other financial indices. ${ }^{428}$ COVID-19 will likely exacerbate this trend to cleaner and greener economic growth. Adding onto the contemporary urge to find the funds for climate stabilization, COVID-19 could aid in turning around individuals' preferences towards living an individually healthier life with less carbon-intensive consumption. Corporations then would be incentivized to shift away from carbonintensive production due to stakeholder pressure. Governmental conditionalities pegged to green transitions but also the finance sector finding explicit value in digitalization growth and implicit long-term socially inclusive value in SRI are likely to happen in the future.

Moreover, climate change has at least two implications for the role of institutional investors in corporate governance. First, it is another area where investors appear to be increasingly pursuing public policy goals. The "Big 3 " have been engaging in rhetoric to push firms to act more responsibly regarding climate change risks. ${ }^{429}$ Recent empirical evidence suggests an actual effect, where higher Big 3 ownership is associated with lower carbon emission levels. ${ }^{430}$ Firms are thus arguably sacrificing profit-making at the altar of public policy without being directly forced by regulation. One explanation why firms may act this way is that they are motivated by long-term interests. ${ }^{431}$ With an increasing preva-

427. Ari Levy \& Lorie Konish, The Five Biggest Tech Companies Now Make Up 17.5\% of the S\&P 500Here's How to Protect Yourself, CNBC NEws (Jan. 28, 2020, 8:01 AM), https://www.cnbc.com/2020/01/28/sp500-dominated-by-apple-microsoft-alphabet-amazon-facebook.html [https://perma.cc/KY9R-DYQU].

428. Id.

429. E.g., Giovanni Strampelli, Are Passive Index Funds Active Owners? Corporate Governance Consequence of Passive Investing, 55 SAN DIEGO L. REV. 803, 829 (2018); Barbara Novick, "The Goldilocks Dilemma": A Response to Lucian Bebchuk and Scott Hirst, 120 CoLUM. L. REV. F. 80, 93-94 (2020); Gadinis \& Miazad, supra note 330, at 1422, 1449-50 (discussing asset managers' calls for "climate-competent boards"); see also Vanguard Investment Stewardship Insights: How Vanguard Addresses Climate Risk, VANGUARD (June 2020), https://about.vanguard.com/investment-stewardship/perspectives-and-commentary/ISHVAC_062020.pdf [https://perma.cc/AK8L-YRZQ] (promoting Vanguard's commitment to ESG investing); Hazel Bradford, Blackrock Ramps up Climate-Related Stewardship - Report, PENSIONS \& INVS. (July 14, 2020, 3:02 PM), https://www.pionline.com/esg/blackrock-ramps-climate-related-stewardship-report [https://perma.cc/FJR92CKL] (explaining that BlackRock is "committed to greater transparency in its investment stewardship activities"); Rob Kozlowski, BlackRock Tallies 974 Engagements with 812 Companies in Q2, PENSIONS \& Invs. (Aug. 5, 2020, 2:06 PM), https://www.pionline.com/esg/blackrock-tallies-974-engagements-812-companies-q2 [https://perma.cc/3KNS-GRJB] (explaining that environmental issues were among the engagement themes BlackRock discussed with companies in its portfolios).

430. José Azar et al., The Big Three and Corporate Carbon Emissions Around the World 18 (ECGI Finance, Working Paper No. 715/2020, 2020), https://ssrn.com/abstract=3553258 [https://perma.cc/PVJ8-68ES].

431. E.g., Andrew Ross Sorkin, BlackRock's Message: Contribute to Society, or Risk Losing Our Support, N.Y. TIMES, (Jan. 15, 2018), https://www.nytimes.com/2018/01/15/business/dealbook/blackrock-laurence-finkletter.html [https://perma.cc/AY9F-34QX] (explaining that BlackRock wants companies it invests in to contribute to the societal good); Larry Fink, Larry Fink's 2021 Letter to CEOs, BLACKROCK, https://www.blackrock.com/corporate/investor-relations/larry-fink-ceo-letter [https://perma.cc/NU55-X83K] (describing how important climate change is to BlackRock's clients); Matthew Ruoss, For Asset Managers, Good 
lence of index investment, investors that are diversified across the entire market may benefit financially from long-term environmental conduct because they may seek to minimize losses across the entire portfolio as diversified "universal owners." 432

Second, institutional investors may want to cultivate a positive image in the media and avoid negative publicity. Fund managers may do this because they believe that it will help them to retain their position in the market for investors. Barzuza, Curtis, and Webber have recently suggested that index fund operators are now promoting ESG issues to appeal to millennial investors. Given that they cannot compete on returns, they need to sell their products by creating an identity associated with a set of values appreciated by consumers. ${ }^{433}$ However, given that many investors are primarily interested in financial gain, another motivation may be that fund managers want to avoid being cast as villains in the public eye. ${ }^{434}$ Regardless of the reason for the fund manager's motives, it seems that institutional investors can no longer eschew the pursuit of public policy goals.

The pursuit of public policy goals is becoming more evident against the backdrop of "stewardship codes" internationally. The first stewardship code was promulgated in the United Kingdom in 2010 and was intended to promote institutional investors as guardian for the interests of dispersed shareholders. ${ }^{435}$ In recent years, stewardship codes increasingly emphasize ESG issues, which add environmental and social concerns to governance. ${ }^{436}$ Institutional investors thus increasingly have a mission to pursue "public" goals. ${ }^{437}$ This will likely continue with COVID-19. Institutional investors have already announced that the pandemic will further induce them to emphasize ESG issues, as it has highlighted social inequality and institutional vulnerabilities. ${ }^{438}$ Early empirical evidence suggests that investors continued to prefer funds with low ESG risks, as shown by the performance of these funds. ${ }^{439}$

Stewardship Is Good Business, FINEXTRA (Aug. 5 2020), https://www.finextra.com/blogposting/19176/for-assetmanagers-good-stewardship-is-good-business [https://perma.cc/L4Z3-N62J] (explaining that ESG screens are now common practice in asset management).

432. Madison Condon, Externalities and the Common Owner, 95 WASH. L. REV. 1, 6 (2020); see also Gadinis \& Miazad, supra note 330, at 1449-51 (emphasizing the public manner in which large asset managers have embraced ESG reform).

433. Barzuza et al., supra note 422; Sharfman, supra note 375, at 6-8; Strampelli, supra note 372, at 12; John Gerard Ruggie \& Emily K. Middleton, Money, Millennials and Human Rights: Sustaining 'Sustainable Investing', 10 GLOB. POL'Y 144, 146 (2019) (discussing the ESG preferences of millennial investors).

434. This may be explained with preference falsification theory. Individuals (and by extension, institutions), may act in a way contrary to their intrinsic preferences because an unpopular opinion will entail a reputational cost. See Timur Kuran, Preference Falsification, Policy Continuity and Collective Conservatism, 97 ECON. J. 642, 655 (1987) (contrasting private and public belief systems); TIMUR KURAN, PRIVATE TRUTHS, PUBLIC LIES 26-30 (1995) (explaining reputational utility). See generally Robert H. Frank, The Political Economy of Preference Falsification, 34 J. ECON. LITERATURE 115 (1996) (discussing how individuals' stated preferences are not their true preferences).

435. Supra note 134 and accompanying text.

436. E.g., Hill, supra note 134, at 514-15; Florencio Lopez-De-Silanes et al., ESG Performance and Disclosure: A Cross-Country Analysis, 2020 SING. J. LEGAL STUD. 217, 220-23 (2020) (surveying ESG disclosure requirements in stewardship codes).

437. See also Novick, supra note 429, at 93 (discussing Blackrock's ESG engagement).

438. Crisis as Catalyst: Corporate Resiliency and the Future of ESG, STATE STREET (2020), https://www.statestreet.com/ideas/articles/crisis-as-catalyst-future-of-esg.html [https://perma.cc/T4PX-CJ36]

439. Fabrizio Ferriani \& Filippo Natoli, ESG Risks in Times of Covid-19, APPLIED ECON. LeTTERS (2020), 


\section{Corporate Governance and the Social Compact}

The discussion of the effects of inequality and climate change reinforces that corporate law is contingent on the larger social and economic environment. 20th century history has shown that crisis-induced reforms and the creation of corporate governance institutions often created paths that countries find hard to deviate from later, even if such deviation would have been welfare enhancing. As Mark Roe wrote in 2003, "[b]efore a nation can produce, it must achieve social peace. ${ }^{, 40}$ Both West German codetermination and Japanese lifetime employment developed not to induce human capital investment, but likely because political circumstances dictated an arrangement that would quell potential labor unrest and shareholder power, ${ }^{441}$ regardless of what the actual effects of these institutions are. Thus, historical circumstances during the Great Depression and after World War II set the stage for late 20th century corporate governance, including financing patterns and ownership structures.

COVID-19 may or may not turn out to be an important juncture in economic history. However, we are already seeing a relative reduction of pro-shareholder institutions, and an emphasis on stakeholder and public interests, in part because COVID-19 has highlighted frictions in developed economies. ${ }^{442}$ A shareholder primacist might consider stakeholder concerns a luxury good to which firms and economies can only pay attention in good times. However, because of feedback from the political and social systems to the economic system, firms will not be able to ignore them. Because median voter preferences are shifting toward concerns about inequality and climate change, legislatures will likely become more inclined to incorporate "stakeholder" and "public" concerns into corporate law. Under pressure from politics and institutional investors, businesses will need to address societal pressures that affect the competitive environment. ${ }^{443}$

At the very least, it appears that "shareholder" countries — such as the United States or the United Kingdom - are slowly edging toward a more pro-employee position and a modified corporate purpose, at least in the public discourse. ${ }^{44}$ This is not necessarily because these positions would be efficient from the internal perspective of the corporate system, but because as a part of the larger economic and political system, corporate governance sometimes must compromise to ensure that it harmonizes with the social compact. To preserve its legitimacy corporate law and governance may be forced to adjust.

\section{COVID-19 AND THE EVOLUTION OF COMPARATIVE CORPORATE GOVERNANCE}

We have seen that outside and inside pressures on firms are changing because of

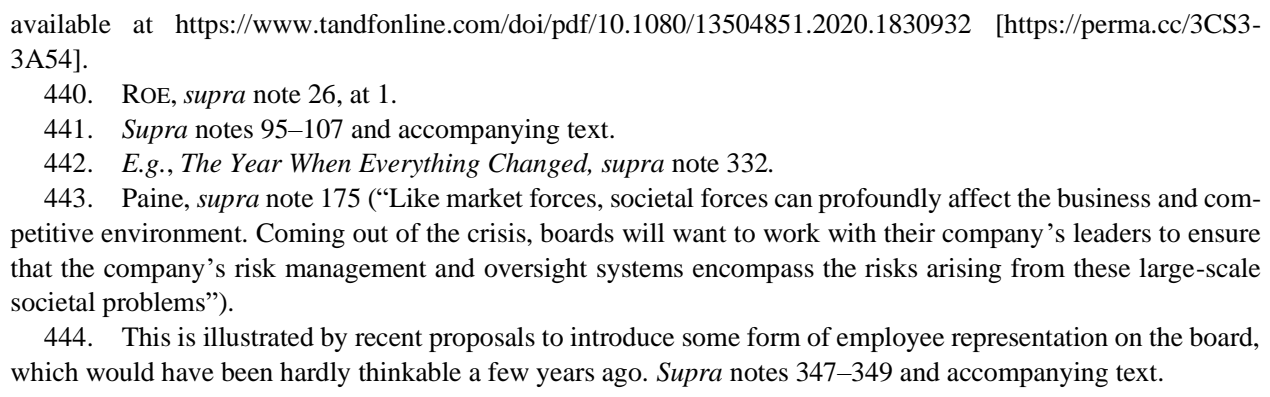

443. Paine, supra note 175 ("Like market forces, societal forces can profoundly affect the business and competitive environment. Coming out of the crisis, boards will want to work with their company's leaders to ensure that the company's risk management and oversight systems encompass the risks arising from these large-scale societal problems").

444. This is illustrated by recent proposals to introduce some form of employee representation on the board, which would have been hardly thinkable a few years ago. Supra notes 347-349 and accompanying text. 
COVID-19. Firms will have to become more resilient, both in terms of their financial and labor practices; governments may be more likely to conscript firms for their own purposes; and pressures to pursue certain public policies will mount, thus pushing firms toward a more "stakeholder-oriented" position in the corporate purpose debate.

Change in corporate governance systems has sometimes been analyzed in terms of evolutionary theory, given that the basic elements of evolution apply, namely variation, retention of characteristics, and the presence of a selection mechanism. ${ }^{445}$ The classic debate about regulatory competition in the United States could be described as an evolutionary account. Regardless of whether one believes that state corporate law is trending toward a "race to the top" or "race to the bottom," the law evolves in a certain direction because laws that are selected more frequently survive in the market. ${ }^{446}$ More to the point, the debate about international convergence in corporate governance rests on the survival not just of laws, but of firms. ${ }^{447}$ As they are in competition with each other. Firms applying the "fittest: corporate law survive because they attract more investment, because they are better run, and because they are thus more successful in the product market. ${ }^{448}$ In this context, the unit of selection is the firm.

In principle, the pandemic could have two effects on the population of firms. First, it may simply eliminate some firms from the market, and thus reward firms resilient to a onetime shock with survival. In this case, there may not be much of an evolutionary effect. This is because the characteristics of firms are less fixed than those of natural organisms. Generally speaking, an evolutionary account of law requires not only the selection, but also the retention of evolved characteristics. ${ }^{449}$ However, law evolves in a Lamarckian rather than in a Darwinian fashion ${ }^{450}$ - meaning that not only inherited, but also acquired characteristics are retained, and because both the law and firms are subject to a form of memetic rather than genetic evolution. ${ }^{451}$ Thus, after the pandemic, firms are not bound by genetic heredity like a biological species but could switch back to practices unadjusted to pandemic conditions. $^{452}$

Still, one-time shocks may have an evolutionary effect because of inertia. Changes made in reaction to the pandemic will not automatically revert, even if they presently do

445. Massimiliano Vatiero, On the (Political) Origin of 'Corporate Governance' Species, 31 J. ECON. SuRV. 393, 394 (2017); Amitai Aviram, Evolutionary Models of Corporate Law 7-11 (2017), https://ssrn.com/abstract=2898413 [https://perma.cc/UQ9V-M2DP].

446. See Ralph Winter, State Law, Shareholder Protection, and the Theory of the Corporation, 6 J. LEGAL StUd. 251, 251-52, 289-92 (1977); ROBERTA RoMANo, THE GENIUS OF AMERICAN CORPORATE LAW 14-24 (1993) (suggesting a "race to the top"); William Cary, Federalism and Corporate Law: Reflections upon Delaware, 83 YALE L.J. 663, 705 (1974); Lucian Bebchuk, Federalism and the Corporation: The Desirable Limits on State Competition in Corporate Law, 105 HARV. L. REV. 1435, 1440 (1992) (generally suggesting a movement to the bottom but noting some nuances).

447. Coffee, supra note 198, at 642; Hansmann \& Kraakman, supra note 11, at 450-51.

448. Vatiero, supra note 445 , at 395.

449. Aviram, supra note 445 , at 10.

450. M.B.W. Sinclair, The Use of Evolution Theory in Law, 64 U. DET. L. REV. 451, 451-52 (1987) (noting that legal evolution is necessarily Lamarckian); Simon Deakin, Evolution for Our Time: A Theory of Legal Memetics, 55 CURRENT LEGAL PROBS. 1, 7, 9 (2002).

451. DAWKINS, supra note 25, at 245; Deakin, supra note 450, at 1-2.

452. Vatiero, supra note 445, at 394 ("[I]ndividuals have the opportunities to change (and not only to adapt to) their environment, and such changes are in accordance with their economic maximisation objectives ..."). 
not have a useful function, unless they are actively deselected because they impede survival. ${ }^{453}$ Moreover, sometimes firms may be locked into a prior choice because switching back is inhibited by prohibitive transition cost. For example, in some cases it may be difficult and expensive to rebuild a worldwide network of supply chains after having moved to a more local one. In other cases, the pandemic may have inflicted a lasting change on the complementary institutional context outside of the control of firms, such as employment law or technology, thus rendering reversion inefficient. ${ }^{454}$

Second, there is a possibility of a persistent evolutionary effect if the pandemic changes evolutionary pressures in the long run. If the virus remains endemic at least as a low-key background disease, occasional lockdowns and smaller economic shocks from localized outbreaks may recur. In this case, one would expect more persistent changes for firms, and entire corporate governance systems could be forced to adjust. If the situation inducing the legal change continues over time, choices will create interest groups that will resist modifications and will oppose a return to original laws, even if it would be welfareenhancing overall. In addition, even if SARS-CoV-2 is eradicated, but the adjustment period is sufficiently long, corporate and legal cultures may have changed and become sufficiently entrenched that it is difficult to return to the status quo ante. While competition from newer firms will eventually erode inefficient adjustments to the coronavirus, this will be a gradual process.

COVID-19 illustrates another important feature of corporate law, namely that its evolution often happens in leaps. We like to think of evolution as an incremental process, but that is not necessarily always true. Stephen J. Gould and Niles Eldredge famously developed the theory of punctuated equilibrium, which seeks to account for rapid speciation. ${ }^{455}$ Often, the fossil record appears to be in stasis over a considerable amount of time, but it then changes rapidly and exhibits few transitional forms in the process. The reason is that a small, isolated subpopulation that is better adapted eventually comes to dominate. ${ }^{456}$ The new equilibrium again persists over an extended period. This is likely the case when the ecosystem changes rapidly, and only those organisms well-adjusted to the new world survive and procreate. In such cases, change happens so quickly that it is not directly observable for paleontologists. Similar tipping points in predator-prey relationships are captured in the Lotka-Volterra system, which is used to describe dynamic models of interaction systems, such as fishery, agriculture, and forestry. ${ }^{457}$

453. Simon Deakin \& Fabio Carvalho, System and Evolution in Corporate Governance, in LAW, ECONOMICS AND EVOLUTIONARY THEORY 111, 124-25 (Peer Zumbansen \& Gralf-Peter Callies eds., 2011).

454. On institutional complementarities, see supra notes 200-207 and accompanying text.

455. Eldredge \& Gould, supra note 24, at 82; Stephen Jay Gould \& Niles Eldredge, Punctuated Equilibria: The Tempo and Mode of Evolution Reconsidered, 3 PALEOBIOLOGY 115, 115 (1977); see generally S.J. Gould, Punctuated Equilibrium - A Different Way of Seeing, 94 NEW SCIENTIST 137 (1982) (further discussing the punctuated equilibrium).

456. Oona A. Hathaway, Path Dependence in the Law: The Course and Pattern of Legal Change in a Common Law System, 86 IowA L. REV. 601, 615 (2001).

457. See generally Colin W. Clark, Mathematical Bioeconomics: The Optimal Management of RENEWABLE RESOURCES (2d ed. 1990) (describing the Lotka-Volterra system); see also Willi Semmler \& Malte Sieveking, On the Optimal Exploitation of Interacting Resources, 59 J. ECON. 23, 23-24 (1994); M. Sieveking \& W. Semmler, The Present Value of Resources with Large Discount Rates, 38 APPLIED Mathematics \& OPTIMIZATION 283, 284 (1997) (showing real-world applications of Lotka-Volterra system dynamics). 
Similarly, in corporate law, when the economic environment changes quickly, only certain types of firms will survive, and only certain corporate governance systems will thrive. Both economic structures and rules tend to adjust rapidly against the backdrop of shocks that disrupt the system at a rapid pace. ${ }^{458}$ Roe has interpreted changes in the American corporate finance system in terms of punctuated equilibrium, ${ }^{459}$ but the point can easily be extended to a broader set of countries. COVID-19 may have started to convert our economic environment from one where gradual development is possible to one with greater uncertainty where, for example, the resilient structures discussed in Section IV.A are more adaptive. Consequently, if COVID-19 is indeed an important turning point, in a few years some jurisdictions may have reached a new equilibrium, as corporate governance did after World War II in many countries. Firms (and countries) competing economically have begun to operate in a very different economic ecosystem. Gradual change may thus give way to a new corporate governance trajectory for the long run.

If we apply evolutionary theory to the macro level and use corporate governance systems as the units of selection (rather than firms), ${ }^{460}$ it may be interesting to speculate whether some jurisdictions are already better pre-adjusted to the coronavirus crisis. One could argue in particular that the description of "resilient" structures in Section IV.A above more closely resembles firms in control-oriented financial systems ${ }^{461}$ (or in "coordinated" capitalist systems when following the varieties of capitalism theory) ${ }^{462}$ than their "arm's length" (or "liberal") counterparts. This is because these firms are already more closely intertwined into local financial networks, and at least in jurisdictions such as Germany and Japan, more coordinated with the workforce. For example, employee representation on the board in Germany and other European countries, or at least a structured relationship with unions may have facilitated more conciliatory measures to protect workers while allowing firms to reduce cost by switching to shorter working hours. ${ }^{463}$

Does this mean that we should expect an economic resurgence in these countries? Such a prediction may be premature because corporate governance is not everything in economic organization. The United States and other "liberal" capitalist systems are also home to some of the most innovative tech firms in the world. In part, the reason may be that capital markets permit them to obtain financing for new ideas relatively effectively, thus enabling the rapid generation of innovation to thrive. ${ }^{464}$ In his comparison between

458. Deakin, supra note 450, at 18-19; Hathaway, supra note 456, at 641-42 (discussing the impact of "critical junctures" for punctuated evolution).

459. Mark J. Roe, Chaos and Evolution in Law and Economics, 109 HARV. L. REV. 641,664 (1996).

460. See Aviram, supra note 445, at 7-8 (contrasting firms and jurisdictions as units of selection).

461. Supra notes 200-204 and accompanying text.

462. Supra notes 205-208 and accompanying text.

463. Jens Dammann \& Horst Eidenmüller, Taming the Corporate Leviathan: Codetermination and the Democratic State 50-52, (ECGI Law Working Paper No. 536/2020, 2020), https://ssrn.com/abstract=3680769 [https://perma.cc/P883-X6WA].

464. E.g., Curtis J. Milhaupt, The Market for Innovation in the United States and Japan: Venture Capital and the Comparative Corporate Governance Debate, 91 Nw. U. L. REV. 865, 866, 875 (1997) (contrasting the size of the U.S. venture capital market with Japan); Joseph A. McCahery \& Erik P.M. Vermeulen, High-Tech Start-Ups in Europe: The Effect of Regulatory Competition on the Emergence of New Business Forms, 7 EUR. L.J. 459, 468-69 (2001) (discussing changes necessary for European corporate governance necessary to be more amenable to venture capital). 
the United States and Japanese startup industry, Milhaupt highlighted the importance of liquidity for financing and high labor mobility in the United States, ${ }^{465}$ which are both typical for "arm's length" economies. In fact, tech giants, such as Amazon, and upstarts, such as Zoom, have been among the most successful since the beginning of the pandemic. ${ }^{466}$ While the above prediction may hold for the preservation of traditional industries, innovation-producing countries such as the United States will continue to benefit from creative destruction and reconstruction. Labor market and educational institutions oriented toward more generalized skills may be better suited for rapid rather than incremental innovation. ${ }^{467}$ Consequently, instead of some corporate governance systems being more resilient to the pandemic than others overall, we may see some countries innovating with new firms, while others may be more successful at bringing their traditional industries through the crisis. $^{468}$

Finally, it is interesting to speculate what effect the resurgence of "stakeholderism" will have on convergence in corporate governance. ${ }^{469}$ Following the accounts of proponents of convergence in corporate governance, stakeholder-oriented corporate governance should eventually be eliminated as inefficient by international competition. ${ }^{470}$ One would therefore expect the trend to dissipate over time. However, the resurgence in nationalism in corporate law would likely counteract it. If economies become marginally less open, the force of competition in product markets will become less important, thus yielding smaller evolutionary pressures across countries, and less international convergence.

\section{CONCLUSION}

We have argued that COVID-19 has resulted in corporate governance that can broadly be canvassed in three categories. First, firms will have to become resilient to the crisis, and consequently long-term oriented. Corporations that are not operating merely on an arm's length capital market basis but are integrated into a network, generating by core shareholders, state ownership, or bank lending may be more likely to survive. Moreover, firms will have to interact in a way with their workers that will result in a healthy workforce. Second, we are likely to see a resurgence of nationalism in corporate governance to ensure that foreign ownership and interconnected supply change do not put national security at risk.

465. Milhaupt, supra note 464, at 883-85, 891-92.

466. Barbara Ortutay \& Mae Anderson, From Zoom to Quibi-The Tech Winners and Losers of 2020, AP NEWs (Dec. 28, 2020), https://apnews.com/article/entertainment-amazoncom-inc-games-coronavirus-pandemic12c4abf85fa06fda7f1959a20c659ba4.

467. Hall \& Soskice, supra note 206, at 30; Roe \& Vatiero, supra note 208, at 69-70; Vatiero, supra note 445, at 400; Which Is the Best Market Model?, ECONOMIST (Sept. 12, 2020), https://www.economist.com/finance-and-economics/2020/09/12/which-is-the-best-market-model [https://perma.cc/FEM4-3KQK] (suggesting that coordinated market economies may be better at incremental changes to create an effective crisis response, whereas liberal systems are better at innovating, e.g., in pharmaceutical research).

468. Some firms may be able to take advantage of the best of both worlds. For example, vaccine developer BioNTech SE is based in Germany but traded on NASDAQ.

469. Hansmann \& Kraakman, supra note 11, at 450-51.

470. On the role of competition for convergence in corporate governance, see Mark J. Roe, Rents and Their Corporate Consequences, 53 STAN. L. REV. 1463, 1472-73 (2001); Ronald J. Gilson, Controlling Shareholders and Corporate Governance: Complicating the Corporate Taxonomy, 119 HARV. L. REV. 1641, 1658 (2006); Pargendler, supra note 212, at 955. 
Third, the existing critiques of inequality and climate change risk will accelerate the trend toward a broadening of corporate purpose toward stakeholderism, which has already begun in the past years. We have interpreted these trends in an evolutionary context. If the pandemic has transformed our economic environment into a more uncertain one, this means that different features of firms and corporate governance systems will be conducive to economic success and survival. To the extent that corporate governance still converges across countries, the end point of this development will be a very different one. 